\title{
From river valley to estuary: the evolution of the Rhine mouth in the early to middle Holocene (western Netherlands, Rhine-Meuse delta)
}

\author{
M.P. Hijma ${ }^{1,2,3,{ }^{*}, \text { K.M. Cohen }}{ }^{1,2,3}$, G. Hoffmann ${ }^{4}$, A.J.F. Van der Spek ${ }^{3,5}$ \& E. Stouthamer ${ }^{1}$ \\ 1 Department of Physical Geography, Faculty of Geosciences, Utrecht University, P.0. Box 80.115, 3508 TC Utrecht, the Netherlands. \\ 2 Utrecht Centre of Geosciences, Budapestlaan 4, 3584 CD Utrecht, the Netherlands. \\ 3 Deltares, P.0. Box 85.467, 3508 TC Utrecht, the Netherlands. \\ 4 German University of Technology, P.0. Box 1.816, Athaibah PC 130, Muscat, Sultanate of Oman. \\ 5 NCK / TU Delft, P.0. Box 5.048, 2600 GA Delft, the Netherlands. \\ * Corresponding author. Email: m.hijma@geo.uu.nl.
}

Manuscript received: November 2008; accepted: March 2009

\begin{abstract}
The aim of this paper is to reconstruct the evolution of the early to middle Holocene Rhine-Meuse river mouths in the western Netherlands and to understand the observed spatial and temporal changes in facies. This is achieved by constructing three delta wide cross-sections using a newly accumulated database with thousands of core descriptions and cone penetration test results, together with a large set of pollen/diatom analyses and $0 \mathrm{SL} /{ }^{14} \mathrm{C}$-dates. Most of the studied deposits accumulated in the fluvial-to-marine transition zone, a highly complex area due to the interaction of terrestrial and marine processes. Understanding how the facies change within this zone, is necessary to make correct palaeogeographic interpretations.

We find a well preserved early to middle Holocene coastal prism resting on lowstand valley floors. Aggradation started after 9 ka cal BP as a result of rapid sea-level rise. Around 8 ka most parts of the study area were permanently flooded and under tidal influence. After 8 ka a bay-head delta was formed near Delft, meaning that little sand could reach the North Sea. Several subsequent avulsions resulted in a shift from the constantly retreating Rhine river mouth to the north. When after 6.5 ka the most northerly river course was formed (Oude Rijn), the central part of the palaeovalley was quickly transgressed and transformed into a large tidal basin. Shortly before 6 ka retrogradation of the coastline halted and tidal inlets began to close, marking the end of the early-middle Holocene transgression.

This paper describes the transition from a fluvial valley to an estuary in unprecedented detail and enables more precise palaeo-reconstructions, evaluation of relative importance of fluvial and coastal processes in rapid transgressed river mouths, and more accurate sediment-budget calculations. The described and well illustrated (changes in) facies are coupled to lithogenetic units. This will aid detailed palaeogeographic interpretations from sedimentary successions, not only in the Netherlands, but also in other estuarine and deltaic regions.
\end{abstract}

Keywords: fluvial, sea-level rise, transgression, bay-head delta, fluvial-tidal, fluvial-marine transition

\section{Introduction}

In the early to middle Holocene, low lying areas (particularly fluvial plains) were transgressed during the post-glacial period of sea-level rise (SLR). Fluvial valleys transformed into estuaries and subsequently into deltas after sea-level rise decelerated in the late Atlantic (Stanley \& Warne, 1994). Globally, extensive research has been performed on the development of estuaries within fluvial valleys during the Holocene transgression (e.g. Allen, 1990; Dalrymple et al., 1994; Dalrymple and Choi, 2007; Frouin et al., 2007). In the central and eastern part of the Netherlands, the adaptation of the Rhine-Meuse system to the transgression has been documented in great detail for the entire Holocene (e.g. Pons, 1957; Verbraeck, 1984; Törnqvist, 1993; Berendsen \& Stouthamer, 2000; Cohen, 2003). Middle to late Holocene coastal response has also been studied intensively (e.g. Beets et al., 1992; Van der Spek \& Beets, 1992; Van der Valk, 1996; Beets \& Van der Spek, 2000; Cleveringa, 2000). However, knowledge of sediment response to sea-level rise near the Rhine-Meuse mouths in the preceding early-middle Holocene is still limited. The facies distribution and sedimentary architecture of early-middle Holocene deposits near the mouths are therefore poorly understood. This is partly due to the depth of the associated deposits: the sediments lie more than $10 \mathrm{~m}$ 
below mean sea level (MSL) and hence data accumulation is difficult and time consuming. Understanding is also poor, because the coastal-deltaic setting of the last 6000 years is quite different than in the first part of the Holocene, making it hard to find modern analogues for early-middle Holocene depositional environments. In particular, the difference in relative SLR (from 8 - $10 \mathrm{~mm} / \mathrm{a}$ in the early-middle Holocene to nearly zero in the late Holocene; Jelgersma, 1961; Van de Plassche, 1982; Hijma \& Cohen, in prep.) provide major differences in boundary conditions. Understanding the driving mechanisms behind facies changes during the transition from a Late Glacial fluvial valley to an estuarine system is important for applications involving the subsurface of subrecent coastal plains (e.g. palaeoreconstructions, construction works, water management) and ancient coastal-plain deposits (mining, oil, hydrocarbon exploration, palaeo-reconstructions).
The aim of this paper is to reconstruct the evolution of the early-middle Holocene Rhine-Meuse river mouth areas in the western Netherlands (Fig. 1) and to understand the observed changes in facies through time, as preserved at the base of the coastal prism. This is achieved by constructing three delta wide cross-sections using a newly accumulated database with thousands of core descriptions and cone penetration test results, together with a large set of pollen/diatom analyses and OSL/ ${ }^{14} \mathrm{C}$-dates. Cross-sectional relationships and environmental indicators were used to identify sedimentary units marking stages of coastal-fluvial transition. Elaborate dating provides ages for these units. Combining age, depth and sedimentary relations gives insight in the timing and celerity of SLR. This integrative, detailed documentation of the early to middle Holocene deposits near the Rhine-Meuse river mouths (this paper) is needed to address the driving mechanisms for changes

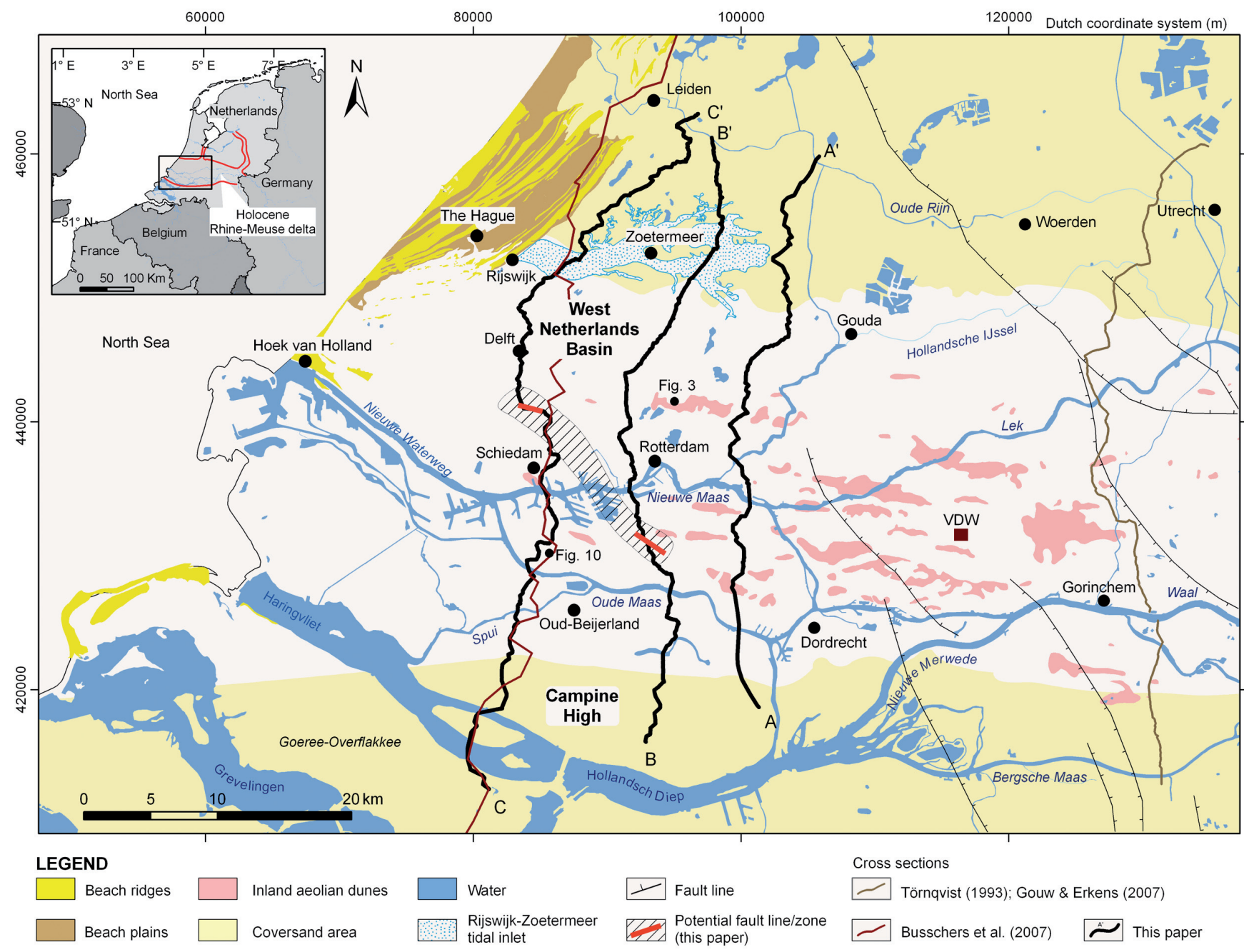

Fig. 1. The outline of the study area and location of cross-sections in the western part of the Rhine-Meuse delta, the Netherlands. Positions of inland aeolian dunes, beach ridges, beach plains and Quaternary-active faults according to the Geological Survey of the Netherlands (TNO, 2009). VDW = study area Molenaarsgraaf of Van der Woude (1983). The position of two cores that are shown in this paper, but fall outside the line of cross-sections is indicated (Figs 3 and 10). 
in facies. In a following paper, these mechanisms will be discussed in more detail, together with a comparison of the observed developments of the early-middle Holocene RhineMeuse system to existing theories on the development of transgressed fluvial valleys, delta evolution and associated sequence stratigraphic concepts.

\section{Geological setting and lithostratigraphy}

This study comprises the area in the west-central Netherlands where the Rhine and Meuse debouched into the North Sea during the Holocene. The study area is located onshore and covers $\sim 50 \times 25 \mathrm{~km}$ (Fig. 1). For the larger part, the area is located within the West Netherlands Basin (WNB), an active depocentre of the North Sea Basin (e.g. Ziegler, 1994). The southwest of the study area is situated on a relatively stable shoulder block of the London-Brabant massif, the Campine High (Fig. 1; Kooi et al., 1998). A fault zone separates this block from the WNB (Van
Balen et al., 2000), but the exact position of active Quaternary faults in the study area is unknown. Differences in both observed and modelled sea-level rise on either side of the fault zone suggest the fault zone to have displace several metres in the last 20,000 years (Vink et al., 2007).

\section{Pleistocene}

The stage for Holocene sedimentation in the study area was constructed by Late Pleistocene Rhine and Meuse rivers. During the Early Glacial-Early Pleniglacial (117 - 60 ka; all ages in calendar years BP) only the Meuse was active in the study area, thereafter both the Rhine and the Meuse (Zagwijn, 1974; Verbraeck, 1984; Busschers et al., 2007). The Weichselian Rhine-Meuse deposits belong to the Kreftenheye Formation (KF, Table 1). The glacial to interglacial transition resulted in river style change from fully braided during the Last Glacial Maximum (LGM, $25 \mathrm{ka} \mathrm{BP}$ ) to single meandering in the middle

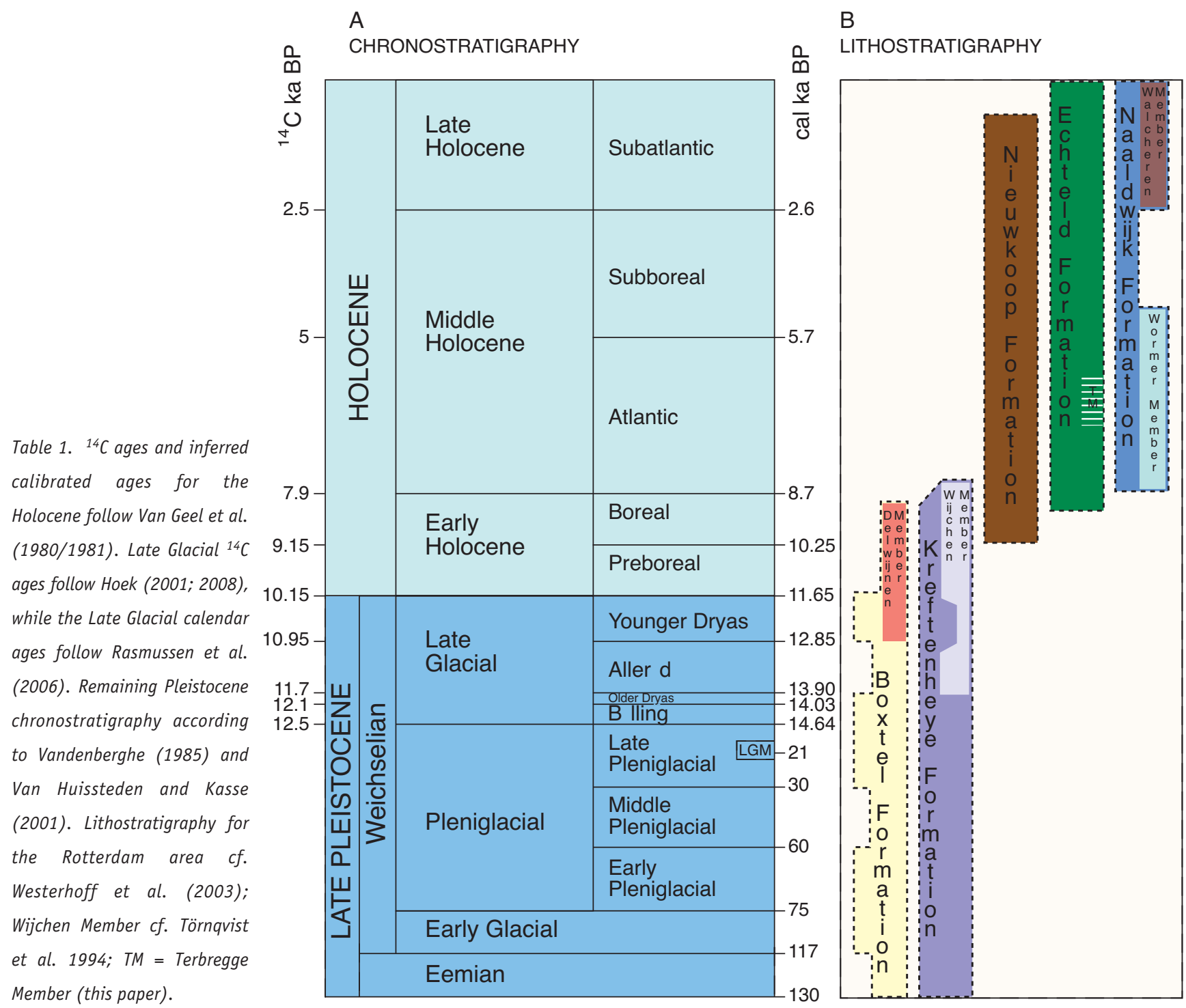


Holocene (Pons, 1957; Pons \& Bennema, 1958; Berendsen et al., 1995; Schirmer, 1995). North and south of the LGM valley, aeolian sandsheets accumulated ('coversands'; Wierden Mb., Table 1, Fig. 1). Between 14.5 - 9 ka channel belts developed that lowered the valley floor and are characterised by fining upward successions. Climate-driven forcing is invoked to explain the incision and coeval change in fluvial style. In the central Netherlands, in areas of net tectonic subsidence, activity of these channel belts lowered the floodplain some 1 - 2 metres below the Late Pleniglacial surface (e.g. Pons, 1957; Törnqvist, 1998; Berendsen \& Stouthamer, 2001). In the study area, elevation differences between Late Pleniglacial and Late Glacial-Early Holocene valley floors have not been resolved. The valley floors seem to converge near the present coastline (Pons, 1954; Törnqvist, 1998). During high discharges thin layers of silty clay loam overbank deposits were laid down (Wijchen Member cf. Törnqvist et al., 1994; Table 1, see also Autin, 2008). Deposition of the Wijchen Member (WM) increased in the early Holocene (EH) during the final full meandering phase when floodplain lowering had halted (Busschers et al., 2007). The Younger Dryas - earliest Holocene meandering channel belts are characterized by deeply scoured channels (Pons, 1957; Berendsen et al., 1995). An exceptionally deep residual channel fill ( $19 \mathrm{~m}$ below floodplain) of $\mathrm{EH}$ age is known from Schiedam (De Groot \& De Gans, 1996). On the northeastern side of the incisive channel belts, inland aeolian dunes fields (up to $15 \mathrm{~m}$ high) developed (Delwijnen Mb., Table 1., Fig. 1), mainly fed by sand blown out of river beds during low stages of discharge (Pons \& Bennema, 1958).

Apart from climatic forced transitions, glacio-isostatical forcing has been proposed to explain pre-LGM/post-LGM fluvial behaviour (Cohen, 2003; Busschers et al., 2007) and spatial differences in relative sea level rise (Kiden et al., 2002; Cohen, 2005; Vink et al., 2007). These papers as well as geophysical modelling studies (Lambeck et al., 1998; Peltier, 2004; Steffen, 2006) place the study area just south of a zone of maximum peripheral crustal upwarping towards and during the LGM ('forebulge crest'), and consequently in an area of accelerated subsidence ('forebulge collapse') in Late Glacial, EH and middle Holocene times.

\section{Holocene}

Globally, SLR had been ongoing since the end of the LGM (Fairbanks, 1989), but the location of the study area was only transgressed near the Boreal-Atlantic transition, 9 ka. The Holocene transgression forced the Rhine-Meuse river system (Echteld Fm., Table 1) to change into a complex estuarine system with frequent river avulsions (Pons et al., 1963; De Groot \& De Gans, 1996) and several large tidal inlets (Beets et al., 1992; Beets \& Van der Spek, 2000). Associated tidal deposits belong to the Wormer Member (Table 1). Before $7 \mathrm{ka}$ the main Rhine-branches debouched in the Rotterdam area, but between 7 - $2 \mathrm{ka}$ in the Leiden area. The Meuse debouched in the Rotterdam area throughout the Holocene (De Groot \& De Gans, 1996; Berendsen \& Stouthamer, 2000).

After the major landward shift of fluvial deposition in the late Boreal-middle Atlantic, relative SLR slowed down (Fig. 2; Jelgersma, 1961; Van de Plassche, 1982) and since then global sea-level remained approximately constant (e.g. Peltier, 2002). Hence it was predominantly ongoing subsidence that contributed to relative SLR in the Netherlands in post-Atlantic times (Jelgersma, 1961). After the middle Atlantic, the balance between the creation of accommodation space and sediment supply changed in favour of the latter and landward shifting of coastal depositional environments halted. This happened diachronously along the coast as a consequence of variations in sediment delivery. The tidal inlets closed one by one in the next millennia, leaving only the Rhine-estuary near Leiden and the Meuse-estuary near Rotterdam to interrupt the barrier ridges in the study area (Beets et al., 1992). During the Subboreal, laterally extensive peat-beds (Nieuwkoop Fm., Table 1) developed in between the river branches - locally as oligotrophic bogs. The largest peat volumes occur at the upstream limit of the study area. Since, the Subatlantic marine ingressions (Walcheren

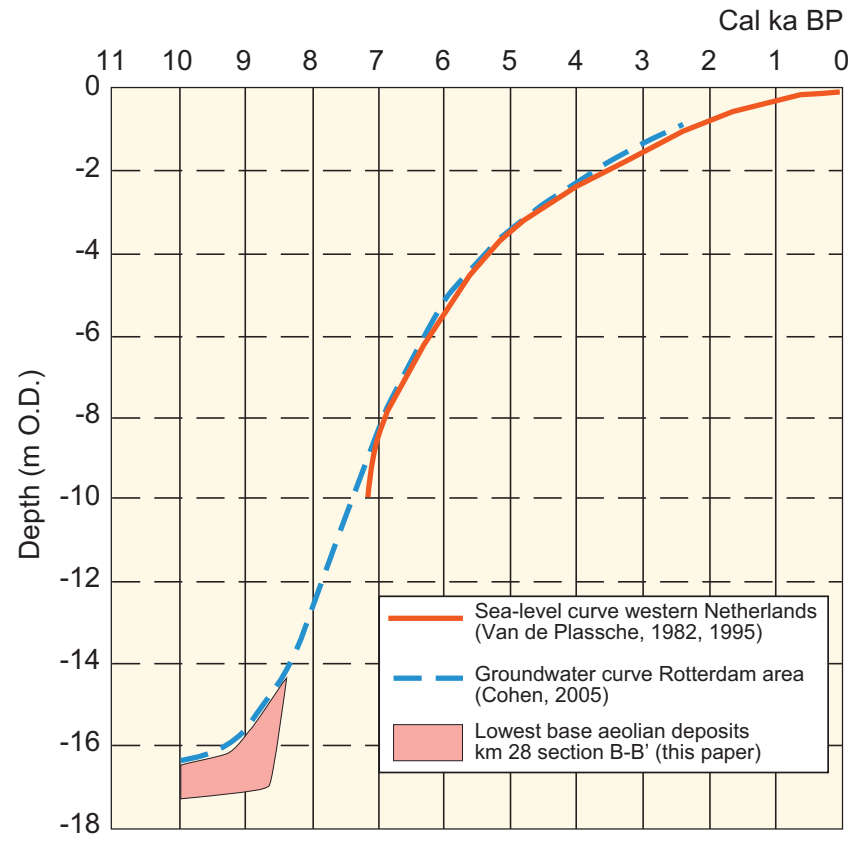

Fig. 2. Relative sea-level curve for the western Netherlands (Van de Plassche, 1982) together with a groundwater curve for the Rotterdam area (Cohen, 2005; location Blijdorp: section B-B' $\mathrm{km}$ 28.5). 
Mb., Table 1) increased coevally with human activities such as peat mining and reclamation (Pons et al., 1963; Beets et al., 1992; Vos \& Van Heeringen, 1997).

From physical modelling it is evident that since the southern North Sea was transgressed $\sim 8000$ years ago, the study area experienced very similar tides as today, with ranges in the order of 1.5 - $2 \mathrm{~m}$. It is inferred that before that time, the Rhine-Meuse estuary in the Southern Bight and Strait of Dover experienced a different tidal regime with most likely microtidal conditions (Van der Molen \& Van Dijck, 2000; Van der Molen \& De Swart, 2001a, b).

\section{Materials and methods}

To facilitate documentation and reconstruction of the build-up of the Holocene succession, three delta wide cross-sections were constructed. The distance between the cross-sections is $\sim 10 \mathrm{~km}$ and they are situated perpendicular to the valley axis (Fig. 1). The southern part of cross-section A-A' was adopted from Gouw (2002) - all other parts are newly constructed.

\section{Acquisition of corings and cone penetration tests}

A total of 828 corings and 724 cone penetrations tests (CPT's; see below) have been used. Most of these reach the Pleistocene substrate. The spacing between data points varies considerably along the lines, but is on average $\sim 110 \mathrm{~m}$. Most data come from the database of TNO (2009). In addition, we used the databases of the municipalities of Rotterdam and Zoetermeer, from Utrecht University (Berendsen, 2005) and from railroad construction offices. At selected locations, we executed 74 hand corings to fill gaps in the available archived data set, to verify past observations and to sample for dating. The total dataset includes descriptions of corings, CPT's and rare outcrops in construction pits which are highly variable in quality and amount of detail. Higher quality corings with detailed descriptions were used for geological interpretations. Of lower quality data only straight forward properties were used for correlation. Surface elevation was verified to $\sim 10 \mathrm{~cm}$ accuracy using the AHN digital elevation model (Rijkswaterstaat-AGI, 2005). All borehole, CPT and other elevation data used relates to the Netherlands' Ordnance Datum (0.D. i.e. 'Normaal Amsterdams Peil'), which approximates present MSL. Due to topographic inversion (differential compaction), channel systems down to $4 \mathrm{~m}$ below the surface could be traced using the AHN digital elevation model and hence borehole placement strategy could be optimized (Berendsen et al., 2007; Berendsen \& Volleberg, 2007). Hand corings were carried out with various drilling devices: Edelman auger, gouge and Van der Staay suction corer (0ele et al., 1983). They were logged in the field at $10 \mathrm{~cm}$ intervals conform Berendsen \& Stouthamer (2001). This included a description of texture, organic matter content, median grain size, colour, calcium carbonate content and other observations. In Rotterdam, two underground railway construction pits were visited in which $\mathrm{EH}$ sediments were inspected, logged and sampled. On occasion, we could observe and sample material from mechanical obtained cores at the facilities of the Bureau Oudheidkundig Onderzoek Rotterdam (B0OR) and TNO that were collected during various engineering projects between 2002 - 2007. At two locations mechanically-cored material was obtained for our mapping project specifically.

CPT's are used to indentify different unconsolidated sediments and are routinely performed during the construction of roads and buildings in the western Netherlands. Resolution of the CPT-logs is in cm, as resistance to cone penetration (sleeve friction, pore pressure) is continuously measured while driving a rod into the ground at a constant rate. The technique and the usage for subsurface reconstruction has been described in detail by Coerts (1996). CPT-logged units can be converted to lithological units using geotechnical relationships, permitted that conversions are verified versus nearby lithological core data. Critical considerations are: (1) the relationship between resistance/friction and lithology is depth dependent, due to increasing weight of the overlying sediments, and (2) a sediment layer must have a certain minimum thickness to arrive at typical CPT-values for that type of sediment. A sand layer in clay has to be $15-20 \mathrm{~cm}$ thick, while a clay layer in sand has to be $40-50$ $\mathrm{cm}$ thick to be distinctly visible in a CPT (Coerts, 1996).

\section{Pollen and diatom analysis}

At TN0, a library of internal reports provided data and interpretations of analyses performed between 1955 and 2008 (Appendix 1, all appendices can be found in the supporting online information: www.njgonline.nl). Sixty-four pollen/diatoms samples from 7 sites were specifically analysed for this study (Appendix 1: H4 - H6). Pollen preparation followed Faegri \& Iversen (1975), while diatom preparation followed Cremer et al. (2001).

\section{Age control}

Proper age control is essential to determine the timing of developments in the study area. Relative ages are provided by lithostratigraphical, architectural and biostratigraphical relations in the cross-sections, but absolute dates are necessary to assess diachronous deposition within identified units. All 
available early-middle Holocene radiocarbon and optically stimulated luminescence (OSL) dates within $3 \mathrm{~km}$ of the crosssection were evaluated resulting in $88{ }^{14} \mathrm{C}$ and 18 OSL dates (online Appendices 2 and 3). Older radiocarbon dates were often obtained from bulk samples which are prone to contamination and hard water effects and should be interpreted with care (Törnqvist et al., 1992). For this study a further $57{ }^{14} \mathrm{C}$ and 8 OSL dates were obtained (Tables 2 and 3 ). For ${ }^{14} \mathrm{C}$ dating of organic samples, cm-thick slices of sediment were treated with a $5 \% \mathrm{KOH}-$ solution and then washed and wet-sieved over a $150 \mu \mathrm{m}$ mesh. From the residue, suitable terrestrial macrofossils were selected using a microscope and submitted for AMS-dating. 0xCal 4.0 software (Bronk Ramsey, 1995; 2001) with the INTCAL04-curve (Reimer et al., 2004) was used to calibrate the radiocarbon dates. Radiocarbon ages of marine shells were corrected for the average marine reservoir effect of 402 years (Stuiver et al., 1986).

The principles of OSL-dating and its application to fluvial stratigraphy were described by Wallinga (2002). For this study eight samples were dated at the Netherlands Centre for Luminescence dating (www.lumid.nl). The dose rate was obtained from radionuclide concentrations determined by laboratory gamma ray spectrometry, assuming water saturation since the time of deposition (20\% water by weight) and taking into account a contribution from cosmic rays. The equivalent dose was obtained from OSL measurements on small aliquots (2 mm diameter) of sand-sized quartz (180 - $212 \mu \mathrm{m})$, using the single aliquot regenerative dose procedure (Murray \& Wintle, 2003). Following preheat plateau tests, a preheat of $240^{\circ} \mathrm{C}$ combined with a cutheat of $220^{\circ} \mathrm{C}$ was adopted. Net OSL signals were obtained through an early background subtraction method (Ballarini et al., 2007). With the adopted procedure a given laboratory dose could be accurately determined and recycling ratios were unity. For each sample at least 26 single aliquot equivalent dose estimates were obtained; dose distributions indicated significant overdispersion, which is attributed to incomplete resetting of the OSL signal in some of the grains at the time of deposition and burial. Such heterogeneous bleaching is to be expected for the Holocene samples as the channels are incised in Pleistocene deposits and older sediments were likely redeposited with little light exposure. To obtain a burial dose from the dose distribution, the finite mixture model of Galbraith \& Green (1990) was applied, using an overdispersion parameter of $10 \%$ (following Rodnight et al., 2006). OSL ages are obtained by dividing the burial dose by the dose rate; quoted uncertainties are the one sigma confidence interval and include all systematic and random errors. Additional information on the OSL methods used and the results obtained is available in the OSL-lab report (Appendix 4).

\section{Construction of cross-sections}

Each core description has been interpreted and divided into lithogenetic units (e.g. floodplain, levee, tidal flat) and key stratigraphic levels (e.g. peat layers, palaeosols) were noted. By comparing neighbouring core descriptions, units were either connected or laterally bounded. CPT's were used as complementary data, since they provide indirect observations of lithology only. In the following section, we will describe the used lithogenetic units and applied criteria, followed by additional remarks about the usage of existing detailed data on the Rijswijk-Zoetermeer inlet (Fig. 1).

\section{Fluvial deposits}

For deposits of fluvial-deltaic origin with no tidal influence, their lithogenetic and architectural principles (summarised in Gouw \& Erkens, 2007) were used as attribution rules during cross-section construction. A channel belt is regarded as the body of sediment (mostly comprised of sand), deposited in a (former) river channel, irrespective of the type of fluvial system. Associated natural levee deposits (sandy/silty clay) of meandering/anastomosing systems normally grade as wings into clayey flood basin deposits. Consequently, each encountered meandering or anastomosing channel belt is assumed to have had a natural levee attached to it. Such levees may or may not have been preserved, and may or may not have been penetrated in neighbouring boreholes. The width of the channel belts and the relative size of accompanying levees varies between fluvial systems (e.g. meandering or anastomosing), but evidently also between individual distributaries (Makaske, 2001; Gouw, 2007). Crevasse deposits share many lithological properties with natural levee deposits. The available information did often not allow distinguishing between these deposits and therefore they were merged into the same unit.

At the base of the Holocene succession, loamy overbank deposits are encountered (WM). This stiff, (blue)gray, silty clay loam (Törnqvist et al., 1994) is normally easily recognizable (Figs 3 - 6). However, from lesser quality core descriptions it is sometimes impossible to judge if the loam is present. In those cases the WM was not drawn. Early Holocene (EH) channel belts are thought to have deposited large parts of the WM (Berendsen \& Stouthamer, 2000; Busschers et al., 2005) and the thickness of the WM was therefore used as an indicator for the location of $\mathrm{EH}$ channel belts (thickest close to the channels). In areas where $\mathrm{EH}$ channel belts were recognized in corings with nearby CPTtests, the latter show distinct sediment characteristics: CPTlogs penetrating $\mathrm{EH}$ channel belts reveal more oscillations in 
grain size than Late Glacial channel belts. This knowledge was then subsequently used to further map EH channel belts with CPT-data.

\section{Fluvial-tidal deposits}

In the study area, the presence of wave-dominated estuaries is a-priori known (Fig. 7). An estuary is commonly defined as the seaward portion of a river system which receives sediments from

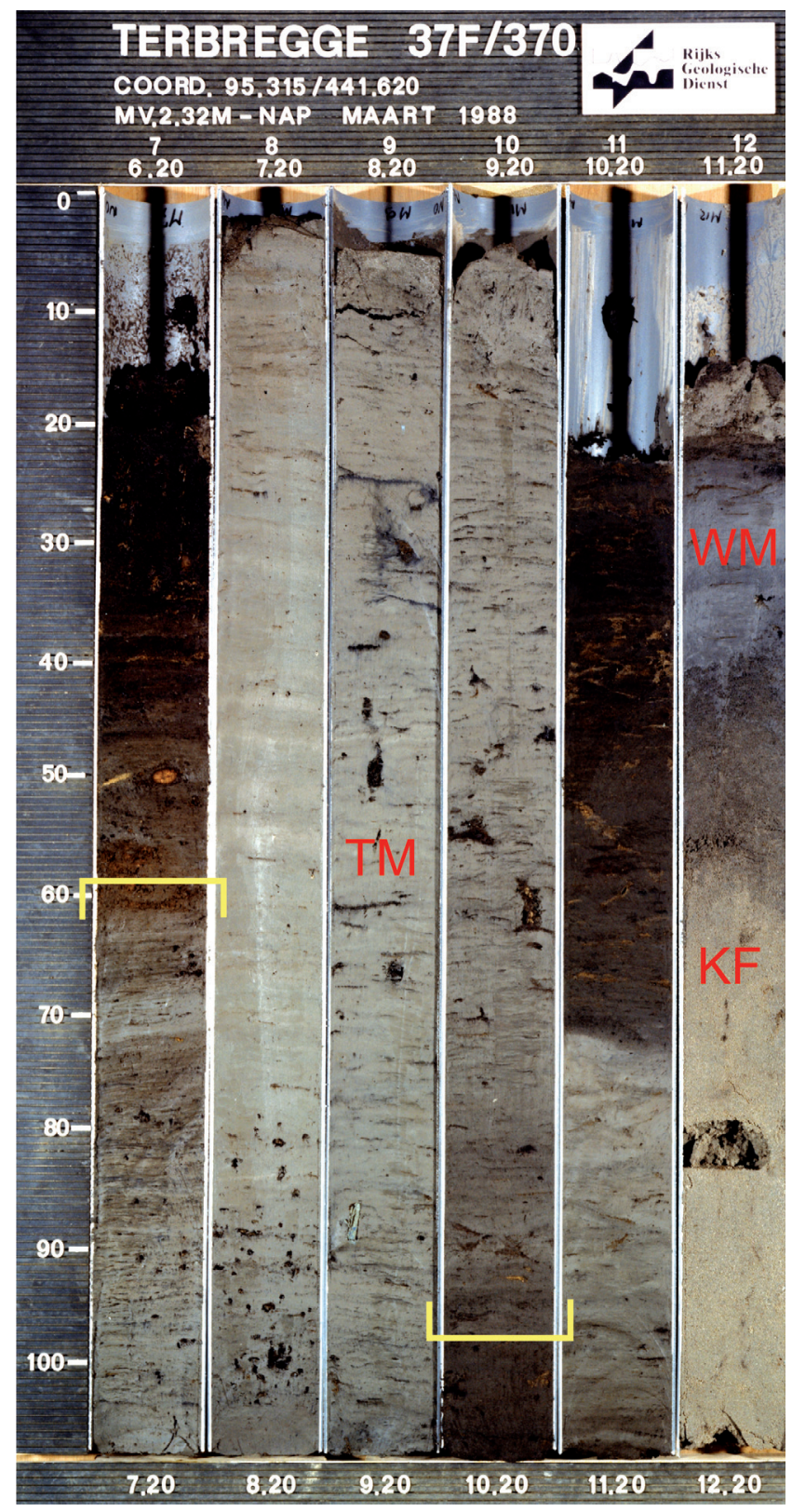

Fig. 3. Core B37F0370 (see Fig. 1). Between the yellow brackets a banded, laminated silty clay with woody debris (occasionally with rootlets) is visible. This facies marks shallow subaqueous deposition in freshwater fluvial-tidal flood basins in the upper estuary of the early Atlantic Rhine. The facies overlies basal peat and early Holocene deposits. TM=Terbregge Member; WM=Wijchen Member; KF=Kreftenheye Formation. both fluvial and marine sources and which contains facies influenced by tide, wave and fluvial processes and extends from the landward limit of tidal facies at its head to the seaward limit of coastal facies at is mouth (Dalrymple et al., 1992). In estuaries, a transition from predominantly fluvial to predominantly tidal deposits via fluvial-tidal deposits occurs (e.g. Terwindt et al., 1963; Van den Berg et al., 2007). In this study, fluvial-tidal deposits are defined as deposits of a predominantly fluvial source with a tidal signature, but deposited under predominantly fresh conditions. The fluvial-tidal zone is which they accumulate starts at the landward limit of the estuary and ends at a certain

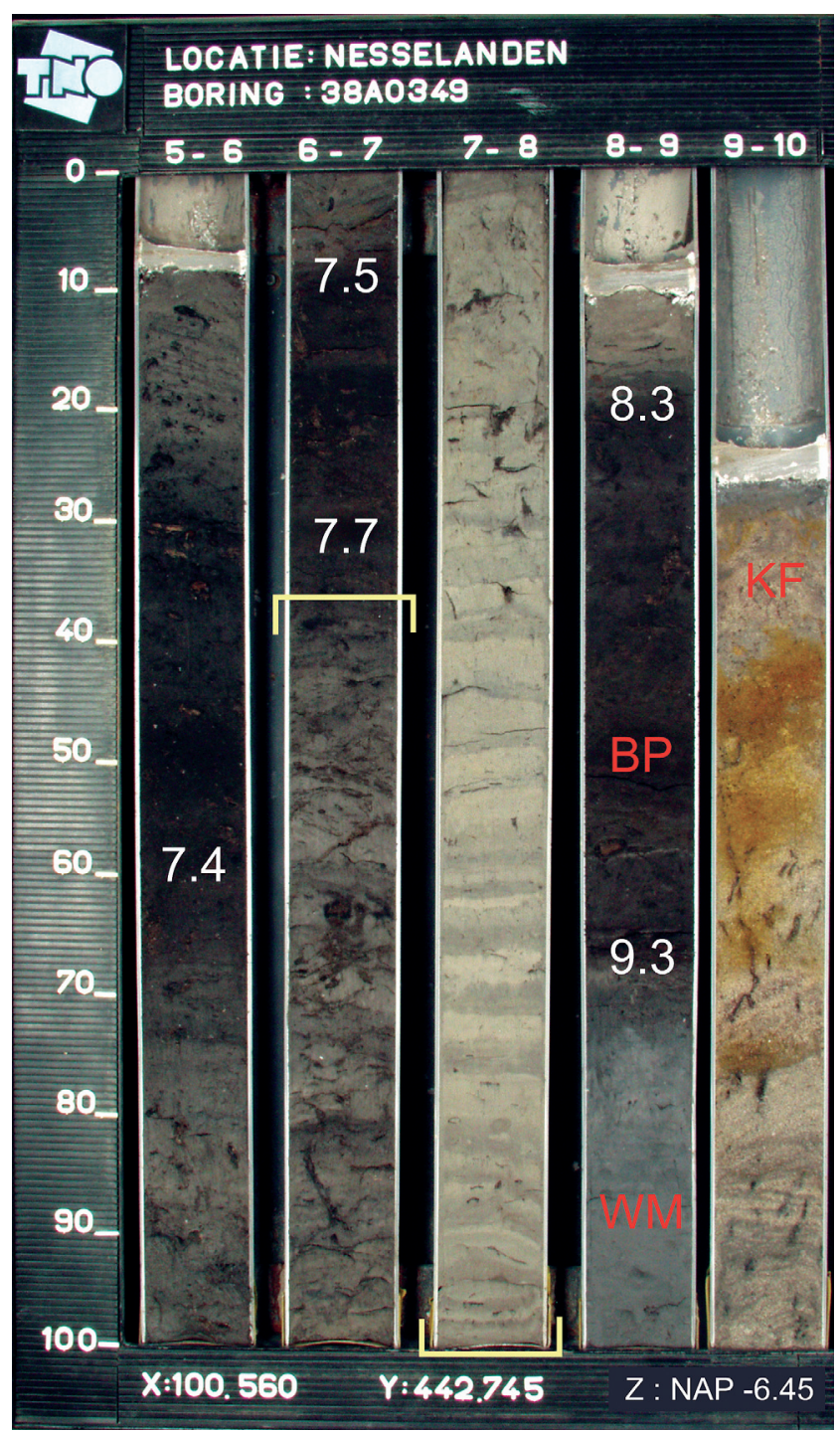

Fig. 4. Core B38A0349 (Fig. 13, km 28). Between the yellow brackets, a light-dark banded clay is visible. This facies marks rapid deposition in fresh, shallow water. Dark bands mark seasonal diatom blooms, suggesting the interval 7-8 $m$ to have accumulated within 24 years $(\mathrm{H}-2)$. Calibrated ages $(\mathrm{ka})$ are depicted in white; decimal dot indicates the sampling position for ${ }^{14} \mathrm{C}$ dating. Surface elevation was corrected from 5.7 to $6.45 \mathrm{~m}-0 . D$. $W M=$ Wijchen Member; $K F=$ Kreftenheye Formation. 


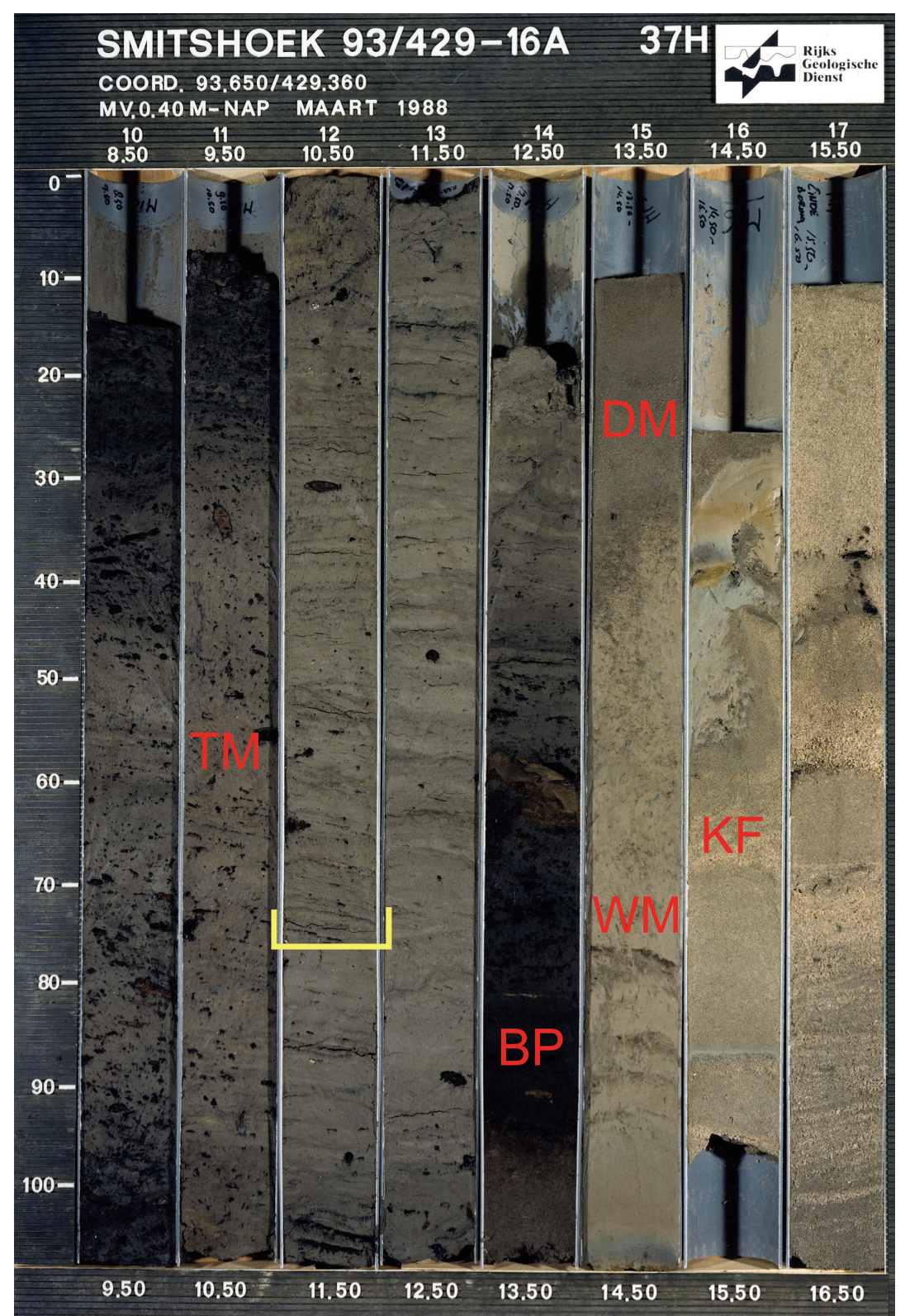

Fig. 5. Core B37H0549 (Fig. 16, km 17). Above the yellow bracket, a banded, laminated silty clay with woody debris is shown (Terbregge Member, TM). The facies is characteristic for fluvial-tidal flood basins $\sim 7$ cal ka BP. The clay overlies the basal peat (BP). Calibrated ages ( $\mathrm{ka}$ ) are depicted in white. Surface elevation was corrected from 5.7 to $6.45 \mathrm{~m}-0 . D$. $D M=$ Delwijnen Member; $M=$ Wijchen Member; $K F=$ Kreftenheye Formation.

point in the estuary; obviously its limits constantly change through time. As such, the zone is less extensive on its seaward side than in the definition of Van den Berg et al. (2007) where it ends at the most seaward occurrence of a textural or structural fluvial signature at high river stage, but similar to the combined fluvial-tidal and transition zone of Terwindt et al. (1963). The zone can have lengths of tens to hundreds of kilometres (Dalrymple \& Choi, 2007).

Pinpointing the landward limit of fluvial-tidal deposits in a succession is very important as they mark the most landward extent of marine influence during the turn-around from transgression to regression and also the location of river mouths in the estuarine basin. Developed diagnostic criteria for the fluvialtidal zone are based on detailed sedimentary structures and sequences (Van den Berg et al., 2007) and are very useful when interpreting outcrops, or undisturbed mechanically obtained core material, but cannot be used when interpreting archived borehole-descriptions. These descriptions also not allow distinguishing between predominantly fresh and predominantly brackish depositional environments. We applied various criteria to identify fluvial-tidal deposits in a systematic way (see below). The fluvial-tidal deposits are merged into the newly introduced Terbregge Member (TM) of the Echteld Formation.

\section{Fluvial-tidal channels}

Sandy channel deposits formed under predominantly fresh water conditions, but with mud drapes formed during tidally induced flow reversal (Fig. 8). They are indicated by the presence of fresh water shells or the mineral vivianite $\left(\mathrm{Fe}_{3}^{2+}\left(\mathrm{PO}_{4}\right)_{2} \cdot 8 \mathrm{H}_{2} \mathrm{O}\right)$. Since it is very rare for vivianite to form under brackish/salt 


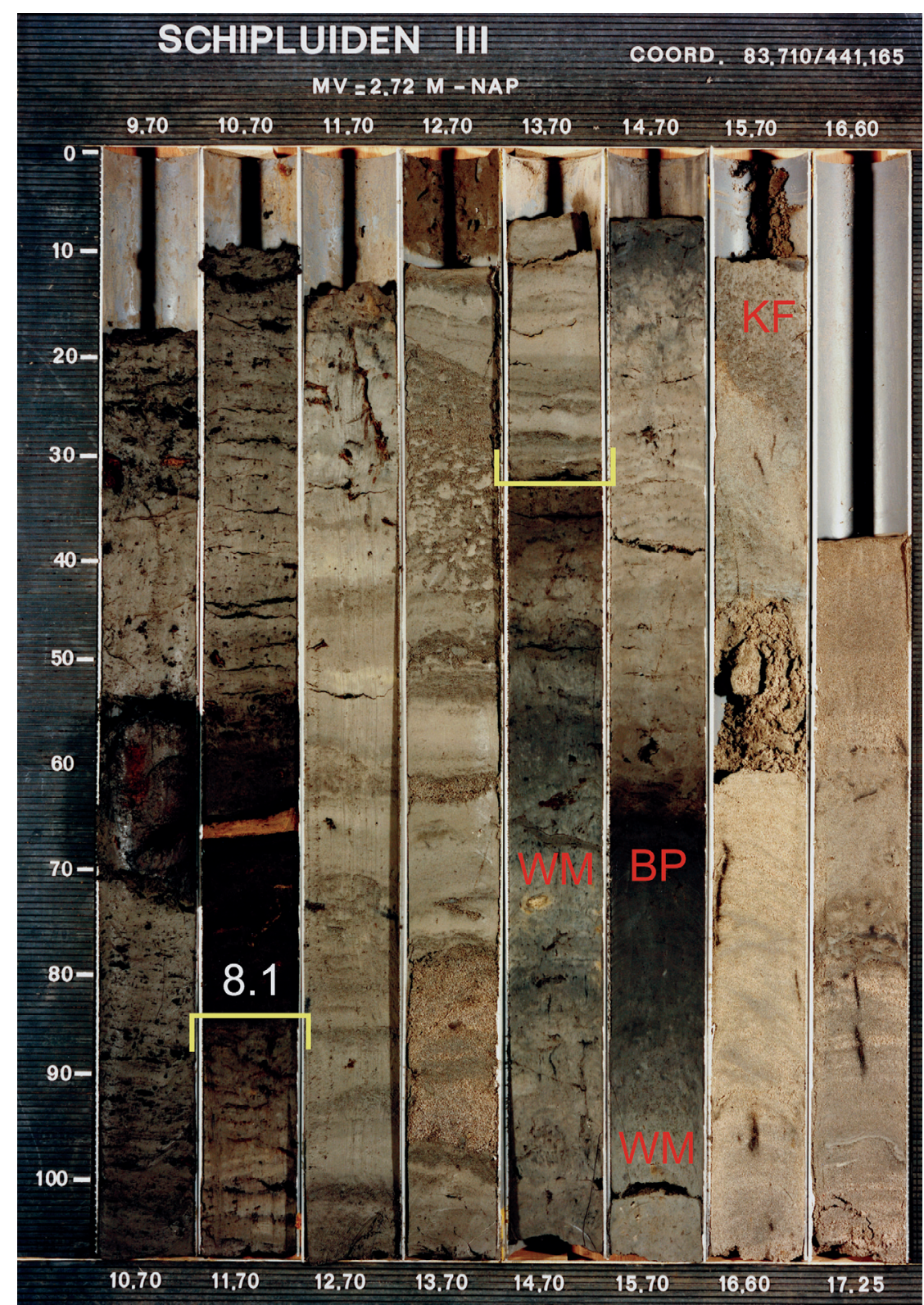

Fig. 6. Core B37E0562 (Fig. 17, $\mathrm{km} \mathrm{38).}$ Between the yellow brackets early Holocene aggrading overbank deposits are shown, with many sand layers and clay pebbles. Note the thickness of the Wijchen Member (WM) and occurrence of organic horizons and a basal peat $(B P)$ within it. Calibrated ages $(k a)$ are depicted in white. KF=Kreftenheye Formation. water conditions (Fagel et al., 2005), its presence strongly suggests a fresh water environment. An absence of shells is also an indicator for fluvial dominance as in tidal dominated deposits many shells are often present. Ichnology was seldomly used as an environmental discrimination tool, as in most cases it was not mentioned in borehole descriptions. Mapped channel systems with tidal signature that could be connected to fluvial channels upstream were regarded as fluvial-tidal channels. In these situations the sand bodies typically had no marked westward continuation: they grade into finer grained tidal deposits of a central area (Fig. 7), known as the 'poor in sand' zone (Van Veen, 1936; op. cit. Terwindt et al., 1963) that is similar to the central estuarine basin of Dalrymple et al. (1992).

\section{Fluvial-tidal flood basins}

The early to middle Atlantic fluvial flood basins were most likely permanently flooded (Van der Woude, 1983). In the fluvial-tidal zone water levels in the flood basins were influenced by the tide. This is evident from the distinct layering in the deposits that is not observed in areas upstream. The deposits can be metres thick and are found over large areas. The silty to sandy clay contains large amounts of layered woody debris (i.e. leaves, twigs, branches; mainly from Salix subspecies; Figs 3, 5 and 9). Pollen and diatom analysis indicate predominantly fresh water conditions although with occasional input of brackish diatoms. The excellent preservation of the organic material is also typical for a fresh water environment. The lack of soil formation and rooting suggests permanent flooding, subaqueous deposition and little vegetation. Therefore, 


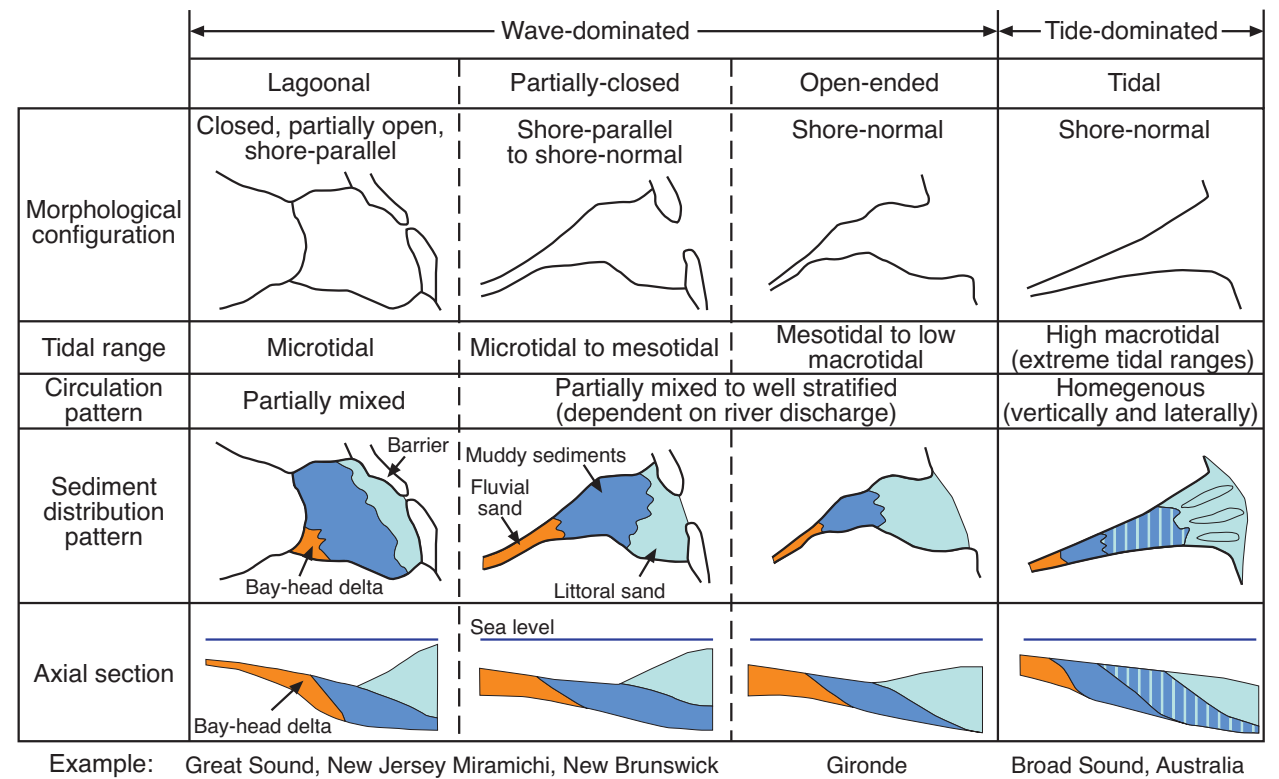

Fig. 7. Classification of several types of estuaries under different boundary conditions. Note the distinct central basin with muddy sediments in between fluvial-tidal and tidal (littoral) sandy deposits in the lagoonal and partially closed types of wave-dominated estuaries. A bayhead delta is formed where the river enters the central basin. The absence of high macrotidal conditions, mark the Rhine-Meuse estuary as wavedominated (after Reinson, 1992).

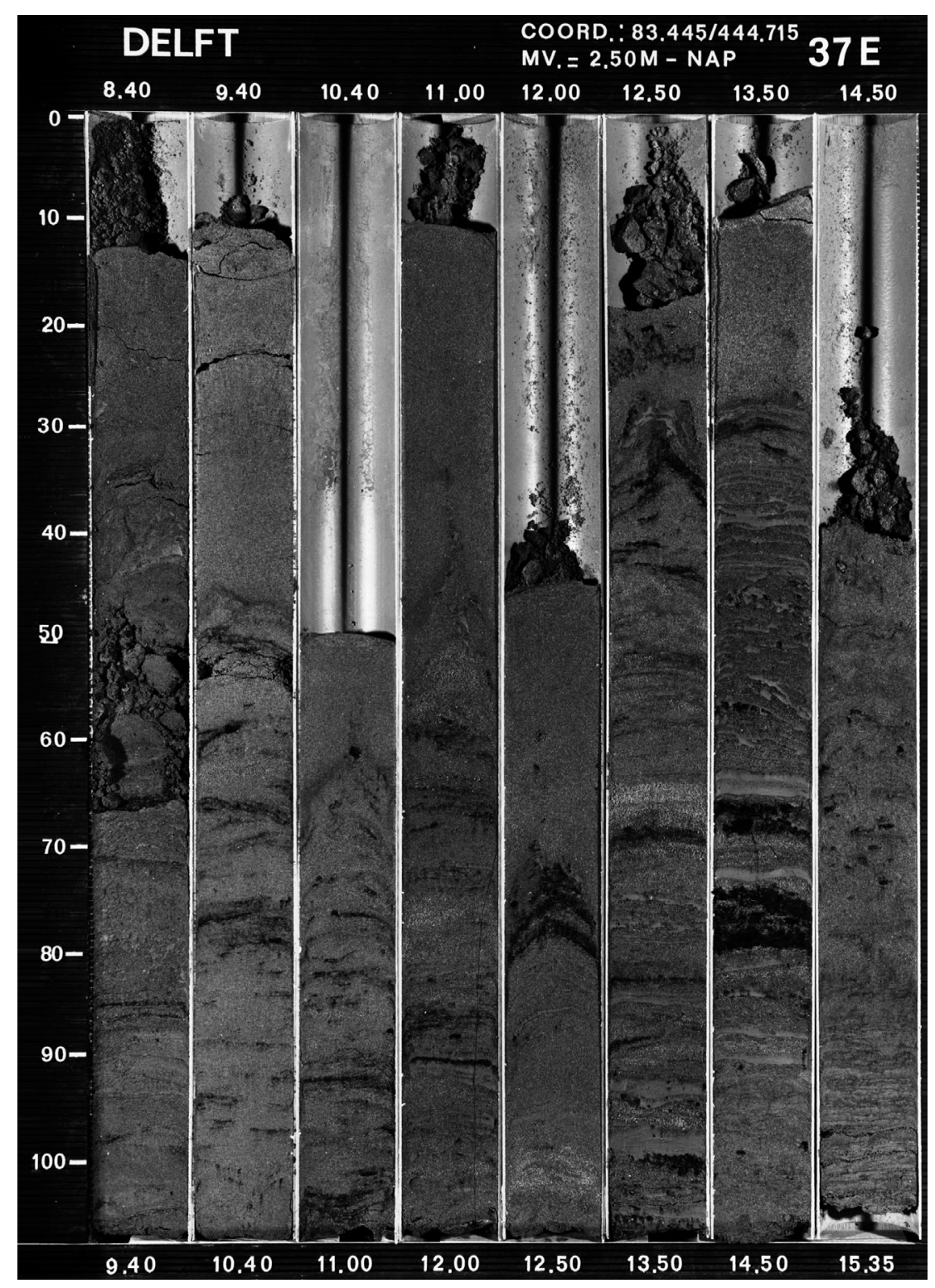

Fig. 8. Core B37E0570 (Fig. 17, km 42). The sandy deposits most likely are part of a bay-head delta complex in the upper estuary. A fluvial source for the sand is evident from the absence of shells, the amount and composition of detritus and blue vivianite stains (not visible here) that are typically formed under freshwater conditions. 
flood basin forests within the study area cannot have produced the bulk of the encountered debris. We consider the upstream fluvial-deltaic area as the main source area for the woody debris as large swamp forests were present there (Van der Woude, 1983).

\section{River mouth: tidal deposits}

We distinguished three tidal facies-units, namely tidal channels (predominantly sand, Fig. 10), sand dominated sub- or intertidal flats (predominantly flaser bedding) and mud dominated sub-, inter-, or supratidal areas (cf. Van der Spek \& Beets, 1992; Fig. 11). Brackish conditions are dominant, indicated by pollen and diatom analysis and by the presence of brackish water molluscs (e.g. Hydrobia sp., Scrobicularia plana, Cerastoderma $s p$.). Brackish water molluscs are generally more robust than fresh water species, therefore better preserved and easy to recognize. The muddy tidal deposits consist of greyish blue, sandy clays with many molluscs, occasional stains of jarosite $\left(\mathrm{KFe}_{3}^{3+}(\mathrm{OH})_{6}\left(\mathrm{SO}_{4}\right)_{2}\right)$ and in more elevated parts numerous phragmites remains. Subtidally deposited silty-clays are often clearly laminated and soft, while intertidal and especially supratidal deposits are stiffer due to periodic wetting and drying and may contain vegetation horizons. Intertidal deposits show strong bioturbation. The clays further contain admixed sea-salt that allows distinguishing it from similar-looking fresh water clays by its excellent, although arbitrary, taste.

The Late Holocene marine deposits (Walcheren Mb.) at the top of the Holocene succession contain similar facies, but these deposits are treated as a single unit, because its details are not the topic of this paper.

Fig. 9. Core B37E0562 (Fig. 17, km 38). Below the yellow bracket the deposits directly south of the bay-head delta are shown, containing many wood fragments, indicative for the nearby presence of a river mouth. Above the yellow bracket brackish deposits occur (based on nearby diatoms counts, H-31, H-34). Around $5 \mathrm{cal}$ ka BP widespread peat formation starts. Calibrated ages $(k a)$ are depicted in white. $T M=$ Terbregge Member; WoM = Wormer nember.

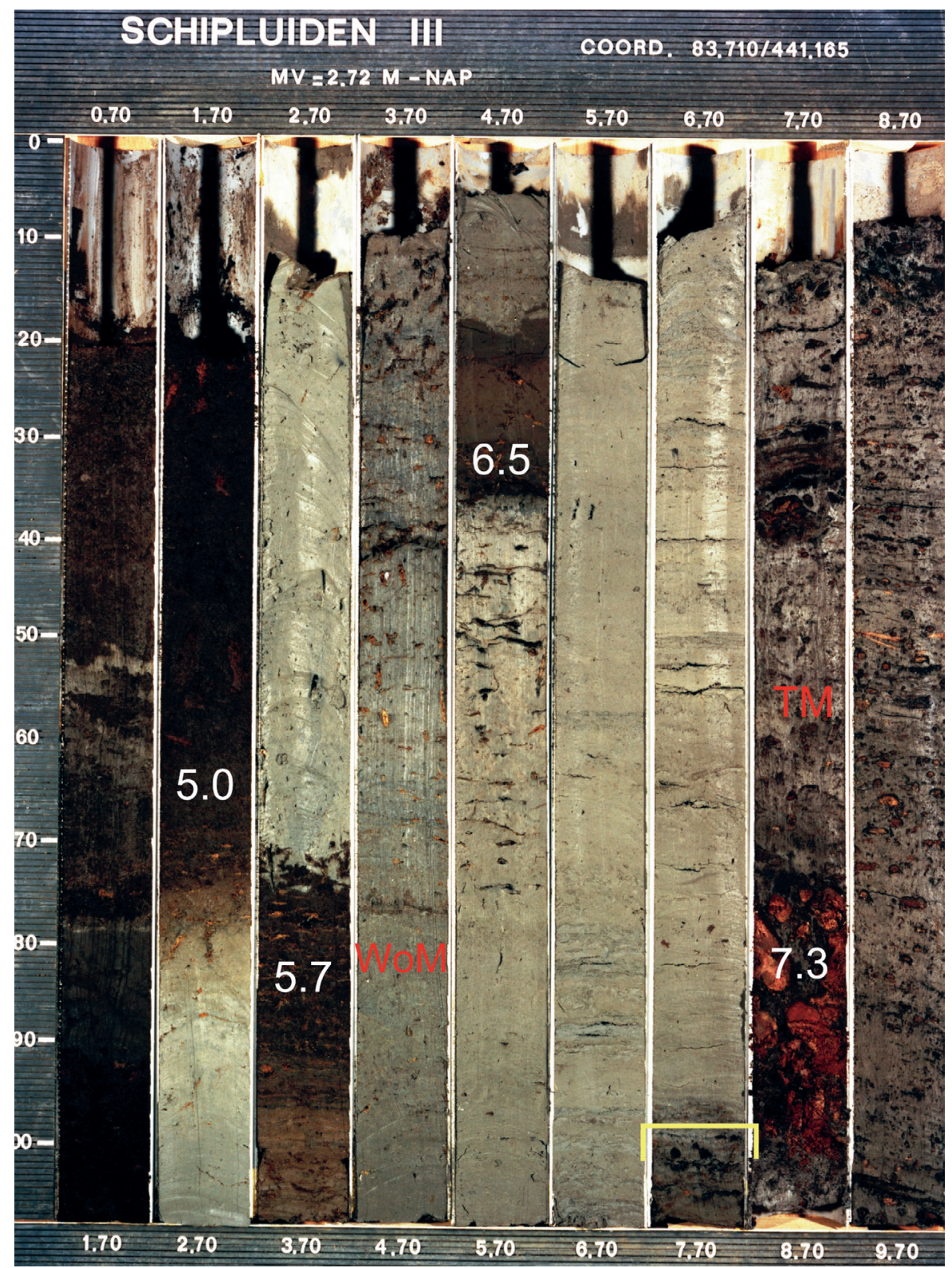




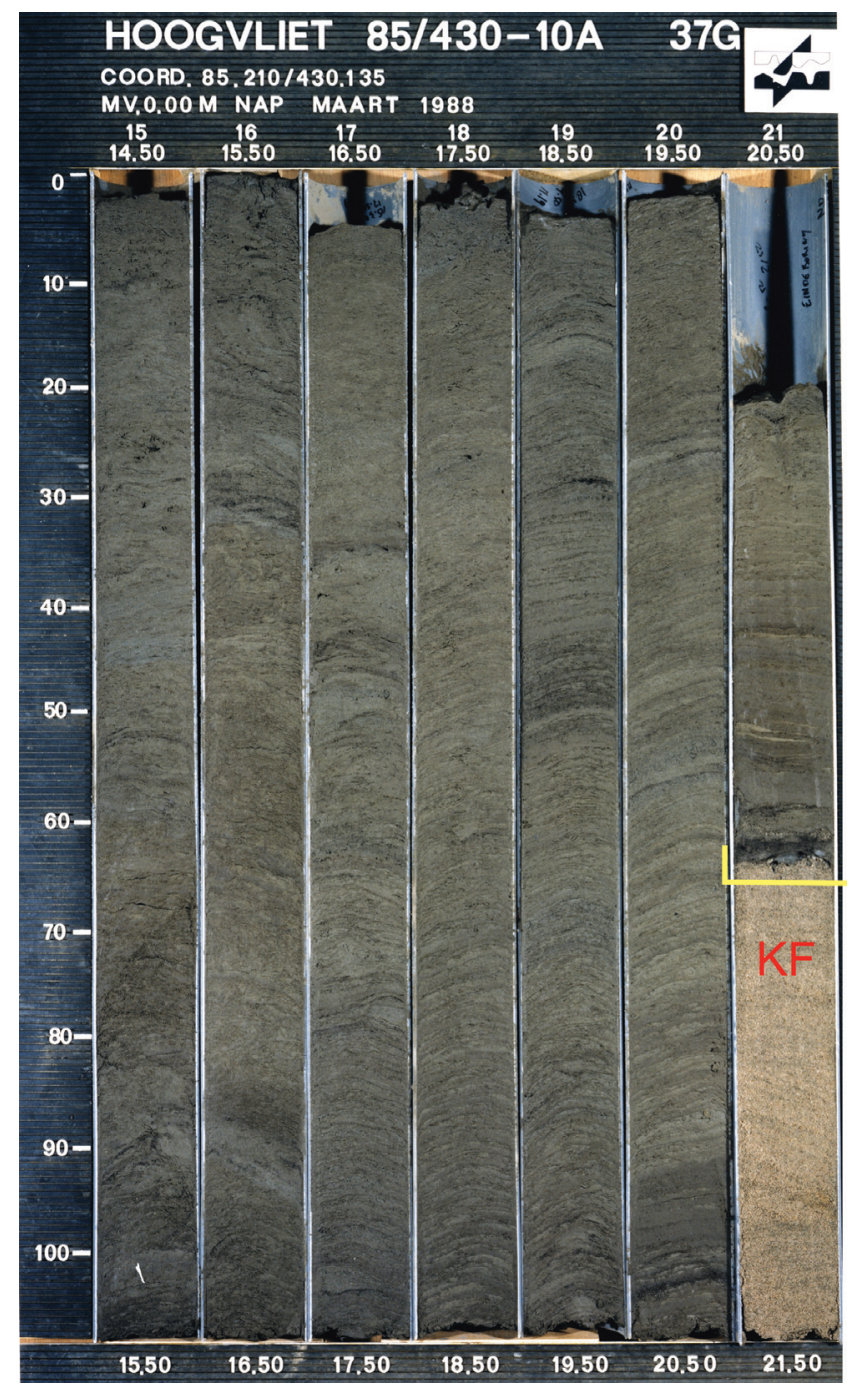

Fig. 10. Core Hoogvliet (see Fig. 1). Above the yellow bracket distinct parallel laminated heterolithic bedding is shown. The succession dates to 7.5 - 6.5 cal ka BP. The deposits erosively overly the Kreftenheye Formation (KF).

\section{Peat}

In the back-barrier area, organic deposits of various compositions formed. We chose to subdivide these deposits according to their main constituents. This reveals the vertical and lateral successions such as progressive drowning and progressive infilling. Gyttja indicates standing-water conditions that occur in lagoonal lakes. Peats indicate infilling of shallower standing water. We classified eutrophic fen-peat (Phragmites, Carex), fen-wood peat (Alnus, Salix) and oligotrophic peat (Sphagnum, Erica). All form under fresh water conditions, but Phragmites can also withstand mesohaline conditions (Chambers et al., 1999). However, salt marshes are normally dominated by Spartina (Silberhorn, 1999). In rare cases, swamp forests can grow under slightly brackish conditions (Stortelder et al., 1998). Fen-wood peat usually forms with mean annual groundwater levels varying between $10 \mathrm{~cm}$ above or below the surface (Stortelder et al., 1998). Fen-peat can form in water depths up to $2 \mathrm{~m}$, but on average forms in mean annual water depths of $\sim 0.5 \mathrm{~m}$ (Den Held et al., 1992).

The basal peat at the base of the Holocene transgression typically lies below fluvial-deltaic flood basin deposits (Figs 4 - 6). Dates from the top of this peat layer provide age control for the onset of fluvial-deltaic aggradation at that position in the transgressed Rhine-Meuse valley. Absence of basal peat can be explained by 1) later erosion or 2) the position of channel belts during peat formation. In the latter case, overbanks deposition or river discharge hindered peat formation. In other words: absence of basal peat is one of the indicators for the position of EH channel belts.

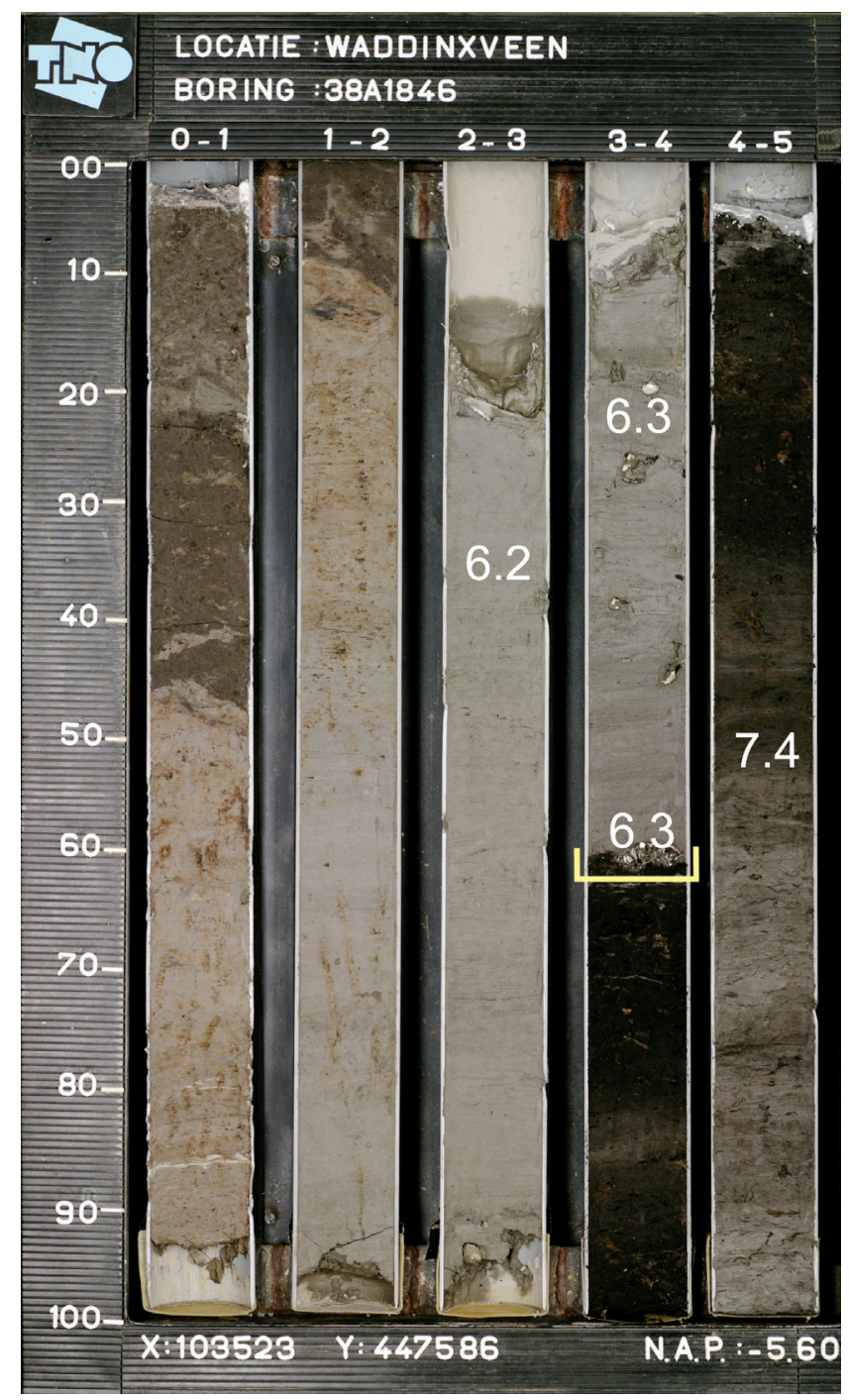

Fig. 11. Core B38A01846 (Fig. 13, km 35). Above the yellow bracket, a shell lag is visible at the base of clayey tidal basin deposits overlying a freshwater peat. Note the homogeneous character of the marine deposits. Calibrated ages in ka BP are depicted in white (shell dates are corrected for the marine reservoir effect). 


\section{Rijswijk-Zoetermeer tidal inlet}

In the study area, deposits marking or flanking the former Rijswijk-Zoetermeer tidal inlet (Fig. 1) have been studied in considerable detail, amongst others in temporary outcrops (Van der Valk, 1996; Cleveringa, 2000; Van der Spek et al., 2007). The $2.5 \mathrm{~km}$ wide inlet had its maximum size between 6.8 - $6.4 \mathrm{ka}$, just before the transition from barrier retrogradation to barrier progradation. Detailed palaeo-ecological analyses near its landward boundary (Fig. 12) indicate that there was no connection to a river branch (Raven \& Kuijper, 1981). The barrier, behind which the Rijswijk-Zoetermeer deposits accumulated, runs southwestnortheast in the direction of Hoek van Holland (Fig. 1). Associated tidal inlet, washover, beach plain, shoreface and aeolian deposits have been described in detail (Van der Valk, 1996; Cleveringa, 2000; Van der Spek et al., 2007). The scale of our cross-sections did not allow distinguishing between these deposits.

\section{Drawing of time lines}

As an additional step, time lines were drawn in the crosssections as an exercise for verifying the lithostratigraphical correlations throughout the cross-sections. The time lines will also aid future palaeogeographic and sediment budget reconstructions in papers to come. The method of Gouw \& Erkens (2007) was used to time slice a cross-section. Drawn time lines are primarily based on dated marker horizons within the flood basin deposits (e.g. peat beds, palaeosols) and stratigraphical relationships dictated by the lithogenetic facies models (previous section). Parts of the cross-section lack datings. In those areas, 3-D interpolations of Holocene palaeogroundwater tables (Cohen, 2005) were used. For a given location in the delta, the interpolation provides maximum ages for the start of eutrophic peat formation at given depths, because the base of the peat marks past groundwater tables. Due to compaction, it is likely that observed peat at any given elevation is somewhat younger than the groundwater model predicts.

The oldest time line (9 ka) approximately marks first deltaic aggradation in the study area. Most vertical accommodation occurred in the early-middle Holocene and the developments during this phase of rapid transgression are the focus of this paper. Therefore, we use a 500-yr interval for the time between 9000 and 7500. Three additional time lines (6500, 5000 and 2500) are provided for the upper part of the section. The

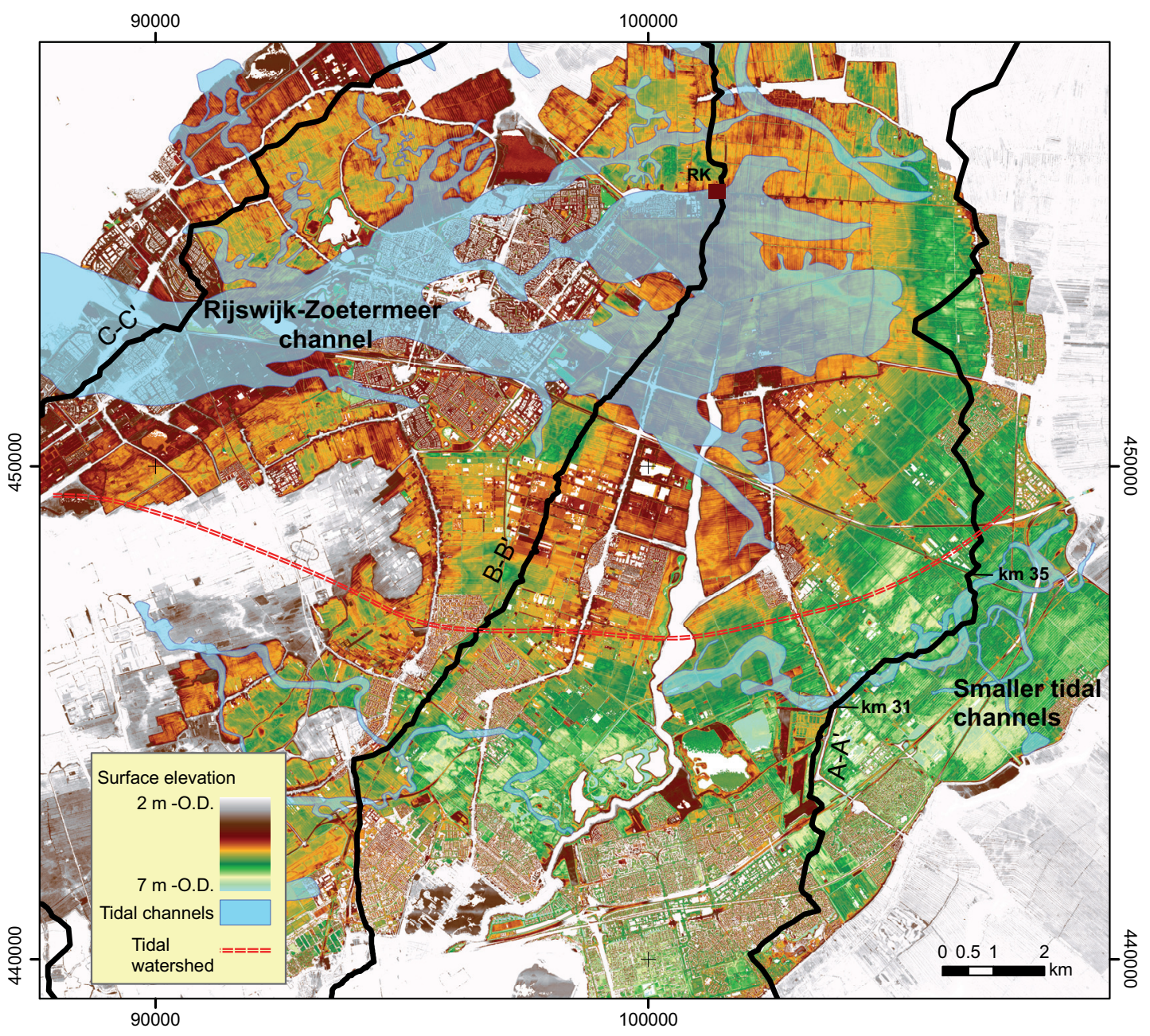

Fig. 12. Annotated visualisation of $A H N$ digital elevation data (Rijkswaterstaat-AGI, 2005) showing the estimated position of the tidal watershed between the Rijswijk tidal system (traceable in the image) and a coexisting tidal inlet system to the south (Hoek van Holland tidal system). Most channel patterns in the elevation model have a tidal nature and relate to architectural elements within a few metres below the surface. $R K$ indicates the study area of Raven and Kuijper (1981). 
reliability of the time lines depends on the quality of time control and stratigraphic relationships. Gouw \& Erkens (2007) estimated the accuracy of time lines in their most downstream cross-section (Fig. 1) to be $\sim 1.0 \mathrm{~m}$. Accuracy of the time lines in our cross-sections varies largely as dates are unequally spread over the study area. In areas with limited time control, we estimate the time lines to be accurate within $\sim 1.5 \mathrm{~m}$.

\section{Naming of fluvial channel belts and tidal inlet systems}

To name the nested incisive channel belts recognized within the Late Glacial-EH valley, we partly adopted the convention of Cohen (2003; his Appendix 1). Identified channel belts are encoded after their presumed time of initiation ( $\mathrm{W}=$ Late Weichselian, $\mathrm{H}$ = Early Holocene) and source (Rhine: R, Meuse: $\mathrm{M}$ ) and inferred order of abandonment $(\mathrm{a}, \mathrm{b}, \mathrm{c})$. Our naming of remaining architectural units comprising the Rhine-Meuse palaeovalley follows the subdivision of Busschers et al. (2007).

Berendsen \& Stouthamer (2001; their App. 3) listed a series of fluvial channel belts, mainly upstream of the study area, named them and introduced numeric channel belt ID's for easy reference. Their identified channel belts connect to features in our cross-sections and where these are simple downstream continuations of upstream channel belts, we adopted the naming and numbering. To name former tidal inlets and estuaries, we used topographical names of the villages above them.

\section{Description and discussion of the cross-sections}

\section{Cross-section $A-A^{\prime}$}

This most eastward cross-section (Figs 1,13 ) is $51 \mathrm{~km}$ long and is based on 191 cores and 336 CPT's. The first $8.5 \mathrm{~km}$ in the south are based on Gouw (2002). The sections northern end is formed by the Oude Rijn channel belt. To the south it reaches into areas of marginal fluvial deposition only: the section stretches well south of the Late Pleistocene-EH palaeovalley. The key to the cross-sections is shown in Figure 14. The combination of ' $\mathrm{H}-$ ' with a number refers to an internal report of TN0 (Appendix 1). References to radiocarbon dates within the cross-sections are indicated by italic numbers between brackets (Table 2, Appendix 2); OSL-dates by italic letters between brackets (Table 3, Appendix 3). The number sign (\#) and accompanying number corresponds with the numbering of channel belts by Berendsen \& Stouthamer (2001). Based on the cross-sections, a schematic overview of channel belt positions is given in Figure 15. In a following paper, the palaeogeography of the study area will be addressed in more detail. The younger strata are treated briefly, as they are not the focus of this paper. The cross-sections can be downloaded as supporting online information (Appendix 5).

\section{Late Glacial and early Holocene rivers}

In section $\mathrm{A}-\mathrm{A}$ ', the sandy top of Late Glacial and earliest Holocene fluvial deposits is encountered at depths between 13 and $18 \mathrm{~m}-0 . \mathrm{D}$. Between $\mathrm{km} 7-12,15.5-20.5$ and $22-28.3$ it is capped by a silty clay loam, covered by the basal peat. Between km $8.5-22$, inland aeolian dunes are occasionally present on and intercalated within the loam. In their direct vicinity, depressions mark channel beds that were the source areas for these dunes. The loam is $1 \mathrm{~m}$ thick on average, but thicknesses reach $2 \mathrm{~m}$ locally. The loam and basal peat are absent between $\mathrm{km} \mathrm{7.5} \mathrm{-} \mathrm{8.5,} 12$ - 15.5, km 20.5 - 22 and km 30 - 35.3. This marks the position of channel belts WM-b/HM-a, WR/HR-a and WR-b/ $\mathrm{HR}-\mathrm{b} / \mathrm{c}$, inferred to be active channels at the time basal-peat formation set on. Overbank sedimentation by these channels explains the local excess thickness of the WM in their immediate vicinity. The valley floor of HM-a, HR-a and HR-c is encountered at lower elevations than the surrounding older valley floors due to incision. Near $\mathrm{km} 8$ a Late Glacial Meuse channel belt is assumed (WM-a), based on the absence of the WM and the presence of aeolian dunes. The age of the basal peat overlying the WM (Fig. 4; 35 - 37), shows activity of HR-a to have ended before $9.3 \mathrm{ka}$. A transported wood fragment at the top of HR-c channel deposits (16 m-0.D.) was dated $~ 9-8.6 \mathrm{ka}$ (42) and two 0SL-dates from this channel an average age of 8.4 $\pm 0.5 \mathrm{ka}(a, b)$. This means that the channel was still active at the time that HR-a had been abandoned. HR-c fringes the cover sand area. The cross-section cuts HR-c twice and at an angle and in reality the channel is smaller. The oldest observed deltaic Rhine channel belts are restricted to km 29 - 34 area. They are the first Holocene channel belts that show to have raised their bed level in response to base-level rise and hence succeeded the HR-b/c channel belts.

\section{Atlantic aggradation}

Widespread, but diachronous, basal peat formation marks the transition to lagoonal-deltaic sedimentation in this area. Radiocarbon dates of the base of the basal peat fall within the range of $9.3-8.8 \mathrm{ka}(35-37,139)$, while the top has been dated at $8.2 \mathrm{ka}(3,34)$. The latter dates provide a local maximum age for the onset of clastic aggradational deposits. Near channels, basal peats are covered by clayey, clastic deposits. Further away from the channels, basal peats grade into gyttja indicating peat 

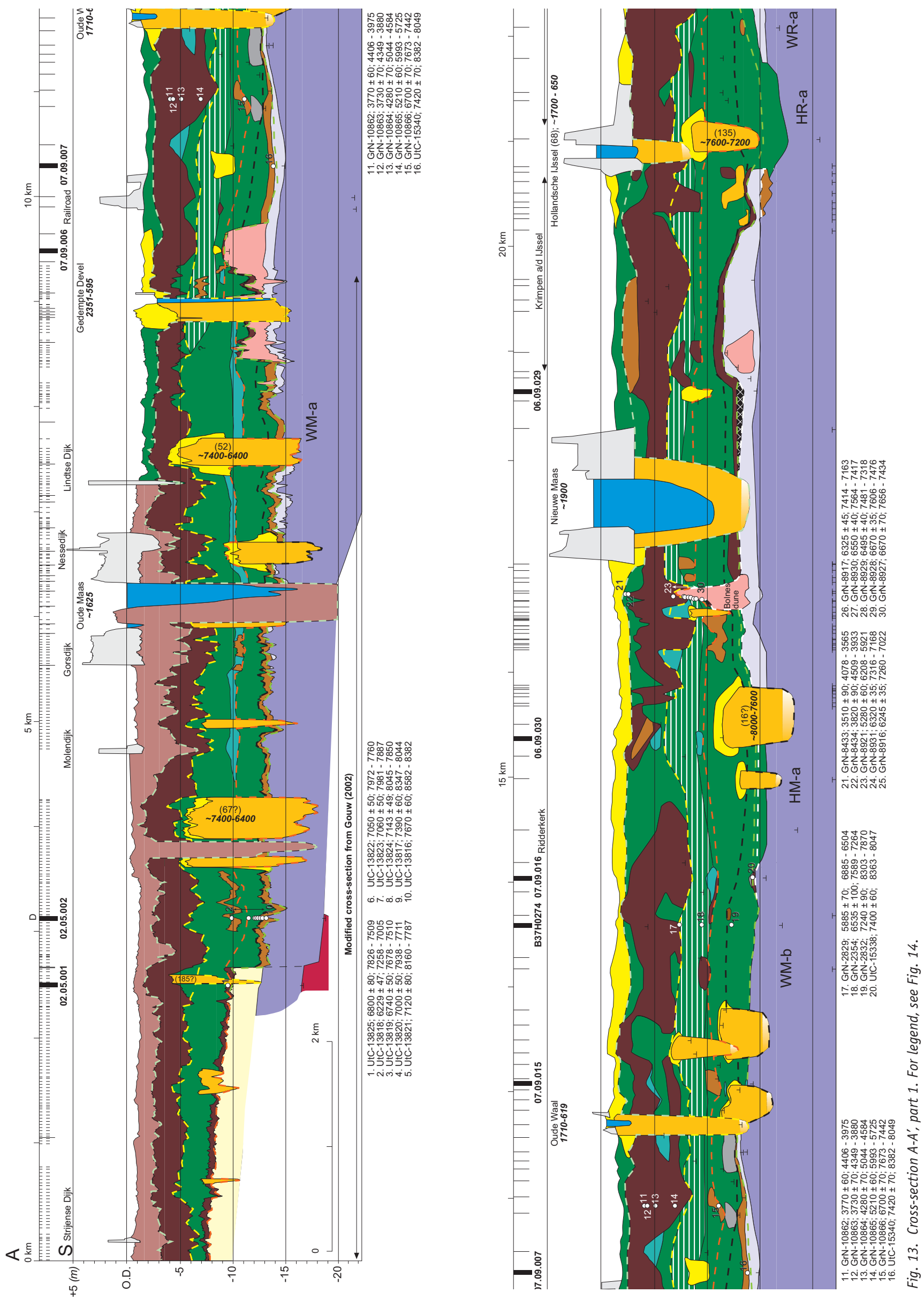

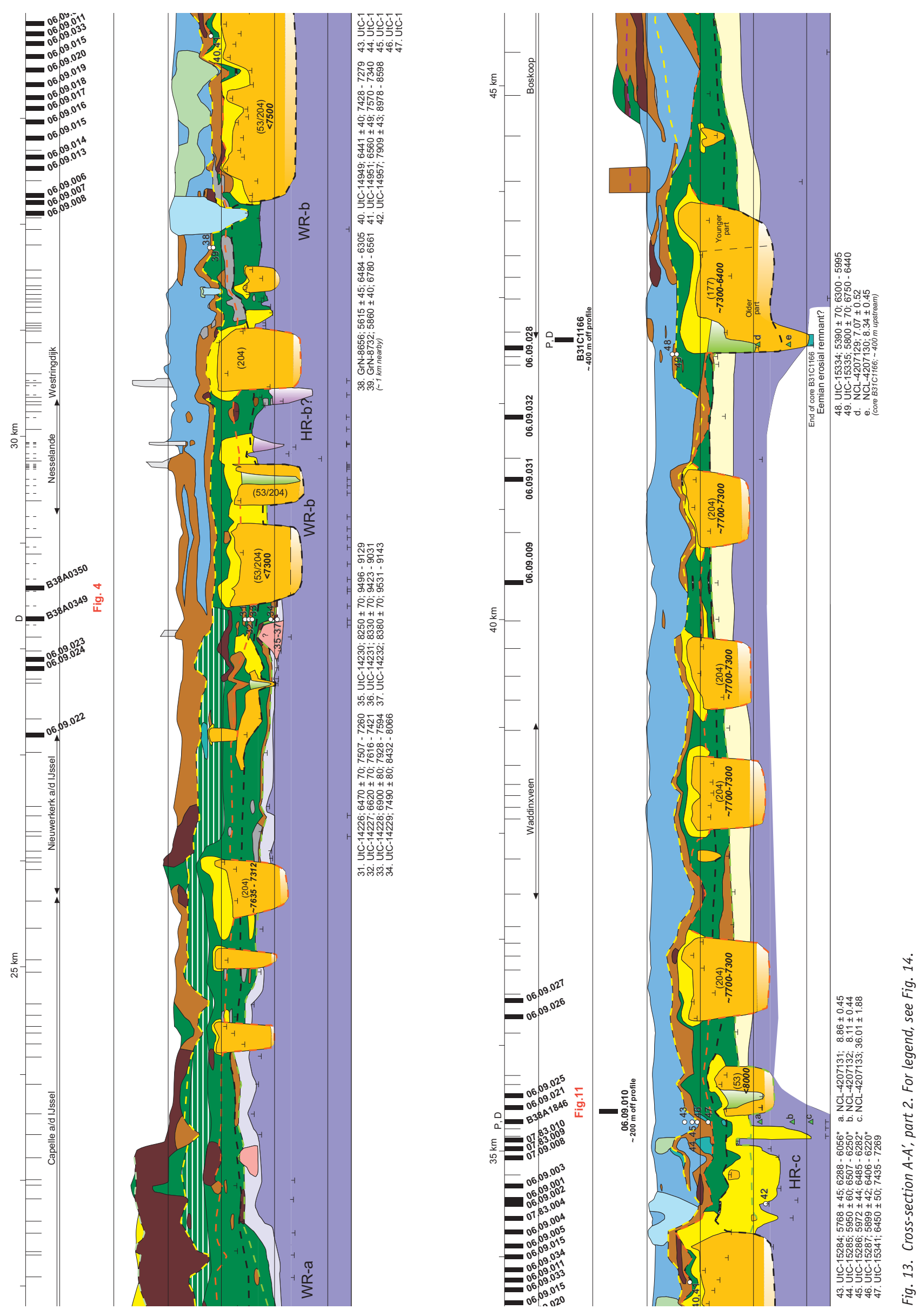
formation could not keep up with groundwater table rise. It suggests that large parts of the study area turned into permanently flooded flood basins, as suggested before by Van der Woude (1983) for an area $15 \mathrm{~km}$ upstream (Fig. 1). At km 27 a sand sheet (105 - $150 \mu \mathrm{m} ; 14-12 \mathrm{~m}$-0.D.) of $\sim 1$ - $2 \mathrm{~m}$ thick and $\sim 1 \mathrm{~km}$ wide is interpreted as the infill of a flood basin lake. The clastic flood basin deposits often show a distinct light-dark banding (Fig. 4). The darker bands are relatively rich in diatoms and can be associated with spring bloom (H-2, App. 1). If true, it suggests rapid sedimentation. Segment $7-8 \mathrm{~m}$ in Figure 4 would have been deposited in only 24 years. Diatom species in this segment (Cocconeis placentula, Cocconeis placentula var. lineate and Cymbella sinuate; $\mathrm{H}-2$ ) indicate shallow fresh water with little flow. To the south, near km 4 (core 02.05.002) scans of diatom content show a short period of predominantly brackish assemblages at that time (De Wolf, 2002). In contrast, in the northern half of section A-A', brackish conditions do not appear until $\sim 6.4 \mathrm{ka}$ (e.g. $38,45,48$ ). It indicates that northerly fresh water flood basins kept receiving steady input of river discharge throughout the early Atlantic.

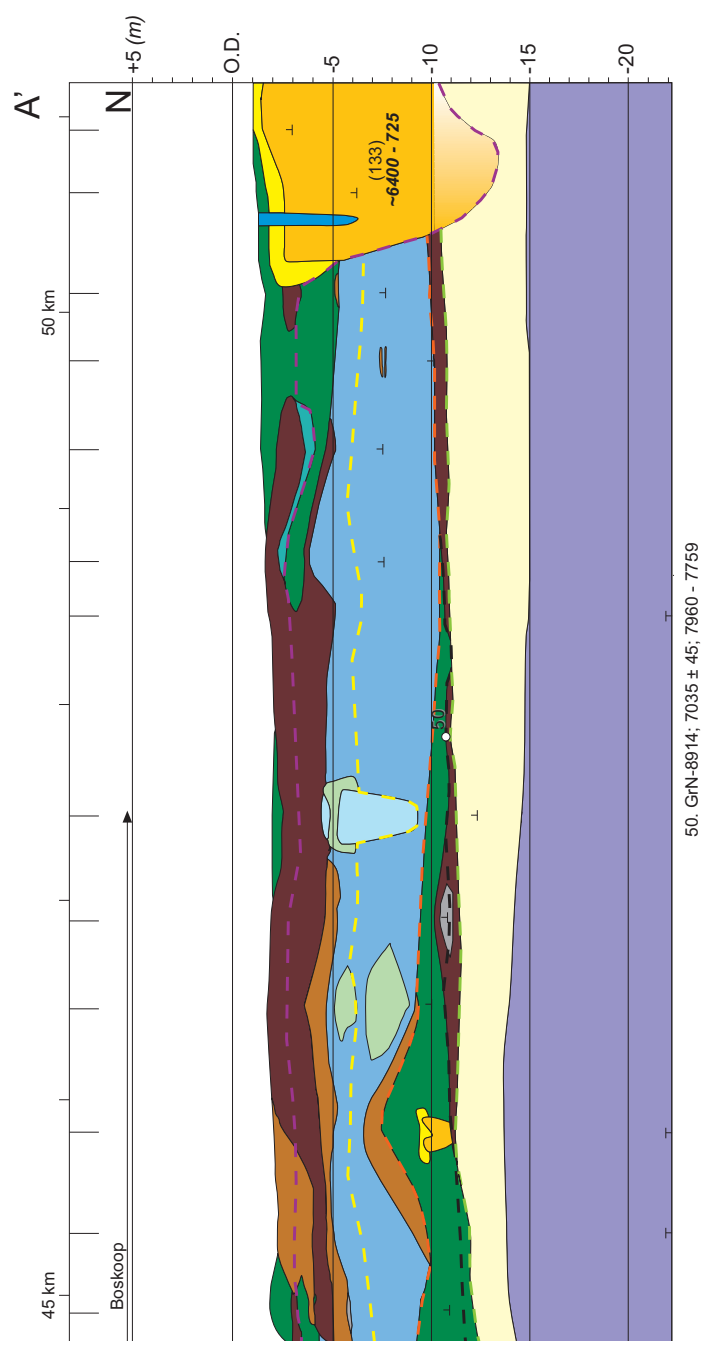

The majority of the earliest aggrading Rhine-channels $(\sim 8.5-7.5 \mathrm{ka})$ is concentrated north of Rotterdam between $\mathrm{km}$ 24 - 34. Additional channels have been recognized at $\mathrm{km} 6.5$ and between km 12 - 16. Considering their position, the three most southern channel belts are attributed to the Meuse. Around 7.7 ka the main Rhine discharge shifted northwards due to an avulsion $\sim 8 \mathrm{~km}$ upstream of section A-A' (Bosch \& Kok, 1994). The new resulting channel belt was positioned within the cover sand area (km 36 - 44; the three sand bodies between km 38 - 41 are the same winding channel belt). The area of the former main river system was left occupied by secondary channels only, and was fully abandoned around $\sim 6.9 \mathrm{ka}$ (channel belt at $\mathrm{km}$ 30.5). Widespread peat formation and humic clay deposition started in the flood basins between $\mathrm{km} 3$ - 30, evident from a discontinuous organic bed at $10 \mathrm{~m}-0 . \mathrm{D}$. The onset of this situation is dated $\sim 7.5 \mathrm{ka}(15,31,41,47,49)$ and is related to abandonment of this area by the main Rhine-branches. The phase of organic bed formation lasted only a few centuries (2, 18). Above the organic bed, the fluvial-tidal flood basin deposits of the Terbregge Mb. (TM) occur widespread (e.g. Fig. 3). They mark the landward end of the estuary after $\sim 7.3 \mathrm{ka}(15,18)$. The start of deposition coincides with the establishment of one main Rhine branch (channel belt \#177, km 43) that drained northwestwardly (Fig. 15), following a renewed avulsion just upstream (avulsion 74; Berendsen \& Stouthamer, 2001). OSL dates from this channel $(d, e)$ have an average of $7.6 \pm 0.7 \mathrm{ka}$. The lower OSL date suggests the presence of fluvial activity before the channel became the main Rhine-branch, with seems valid because it is situated within a depression of the cover sand. To the north of this channel, a tidal flood basin was present since $\sim 7.5 \mathrm{ka}$ (based on 50 ), indicated by the frequent occurrence of Hydrobia and Cerastoderma shells. The tidal flood basin was most likely connected to the same downstream tidal inlet as channel \#177. After $\sim 6.4 \mathrm{ka}$, following a third major avulsion some $40 \mathrm{~km}$ upstream section A-A' (Berendsen \& Stouthamer, 2001), the main Rhine branch shifted north (\#133, km 50) into the tidal flood basin that immediately freshened. The new branch possibly debouched into the North Sea through the same tidal inlet as channel \#177. The tidal basin was gradually filled and after $5 \mathrm{ka}$ the Rhine started to progradate through the basin and developed a $2 \mathrm{~km}$ wide meandering channel belt. Progradation of the river mouth is also indicated by the shape of surrounding barrier ridges (Beets et al., 1992). The avulsion left the area south of $\mathrm{km} 44$ abandoned from steady fluvial sediment input after $\sim 6.4 \mathrm{ka}$ and peat formation started fairly synchronous over great distances (9 - $6 \mathrm{~m}$-0.D., 17, 39, 144, 145). South of km 24, mainly fen-wood peat was formed, while more to the north Phragmites- 
Naaldwijk Formation - Shallow marine deposits

Walcheren Member

Undifferentiated

\section{Wormer Member}

Mud dominated intertidal flat

(clay with silt/very fine sand layers)

Sand dominated intertidal flats

(sand/silt with clay layers)

Tidal channel deposits

(predominantly sand)

\section{Nieuwkoop Formation - Autochtoneous organics}

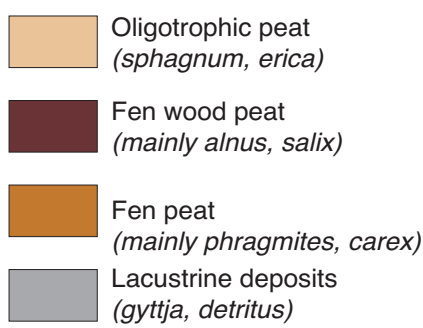

\section{Echteld Formation - Estuarine/deltaic Rhine-Meuse deposits}

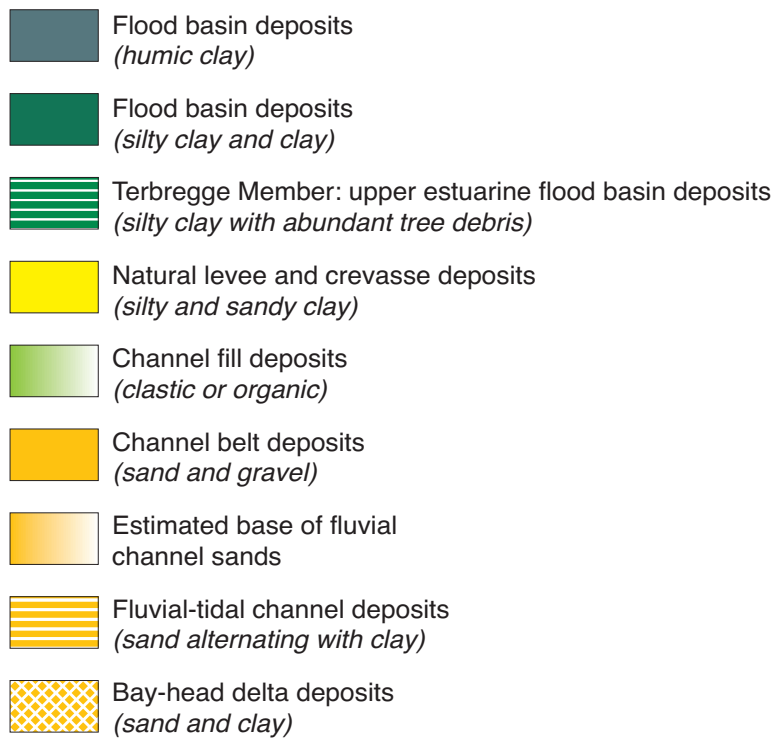

Kreftenheye/Urk Formation - Valley Rhine-Meuse deposits

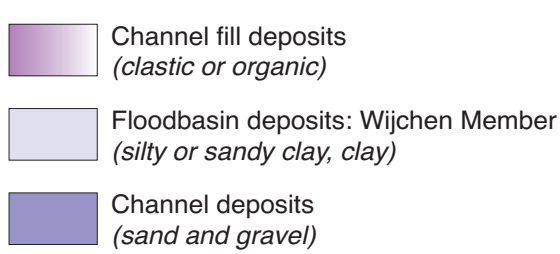

\section{Boxtel Formation - Aeolian and local deposits}

Mainly aeolian deposits

(fine sand and silt)

Delwijnen Member: aeolian deposits

(sand)

\section{Eem Formation - Shallow marine deposits}

Undifferentiated erosional remnant

\section{Time lines}

$$
\begin{aligned}
& \text { - = - - } 2500 \text { cal yr BP } \\
& \text { - = - " } 5000 \text { cal yr BP } \\
& =-=-6500 \text { cal yr BP } \\
& \text { - - - . } 7500 \text { cal yr BP } \\
& \text { - - - . } 8000 \text { cal yr BP } \\
& \text { - - - " } 8500 \text { cal yr BP } \\
& \text { - - - } 9000 \text { cal yr BP }
\end{aligned}
$$

\section{Miscellaneous} (undifferentiated)

Vegetation horizon

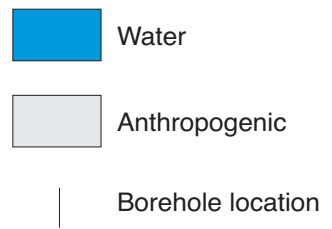

$$
\begin{aligned}
& \text { Mentioned or self executed coring } \\
& \text { (with corenumber) } \\
& \text { P3E0245 } \\
& \text { PD Pollen analysis available for core (Appendix 1) }
\end{aligned}
$$

Cone penetration test

$\perp$ Penetration depth

T Core continues deeper

$1 \quad{ }^{14} \mathrm{C}$-sample

(lab number; radiocarbon age; range in cal yr BP)

2 OSL-sample (lab number; range in ka BP

(133) Aggrading channel belt ID 6400-725 period of activity (cal yr BP)

HR-a Incisive channel belt (introduced in this paper) (Late Glacial - EH)

$\downarrow \uparrow \quad$ Late Glacial-Early Holocene active fault

Fig. 14. Key to the cross-sections (Figs 13, 16, 17). Lithostratigraphical nomenclature as in Table 1, with partial lithogenetic subdivisions - see text for discussion. 


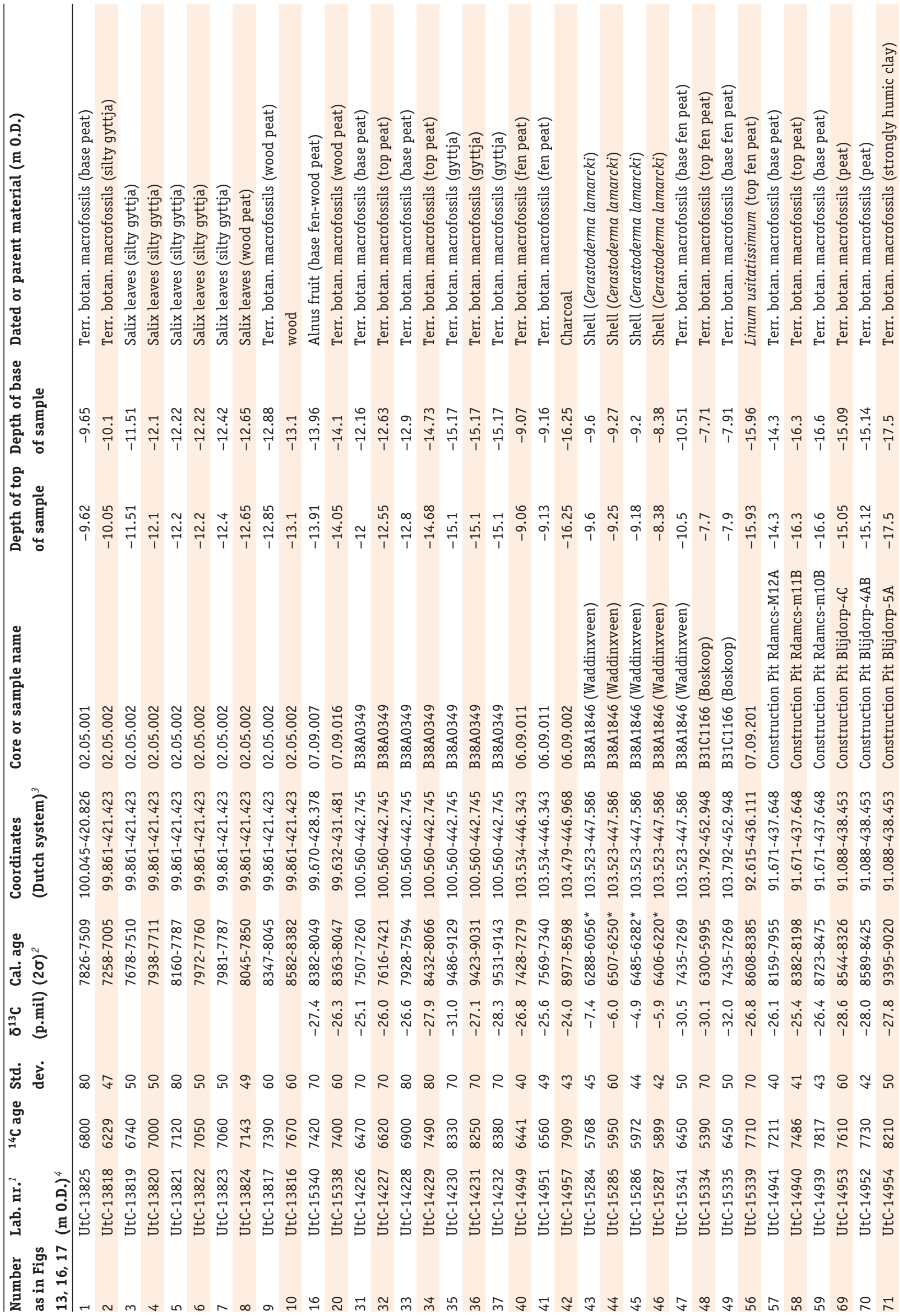




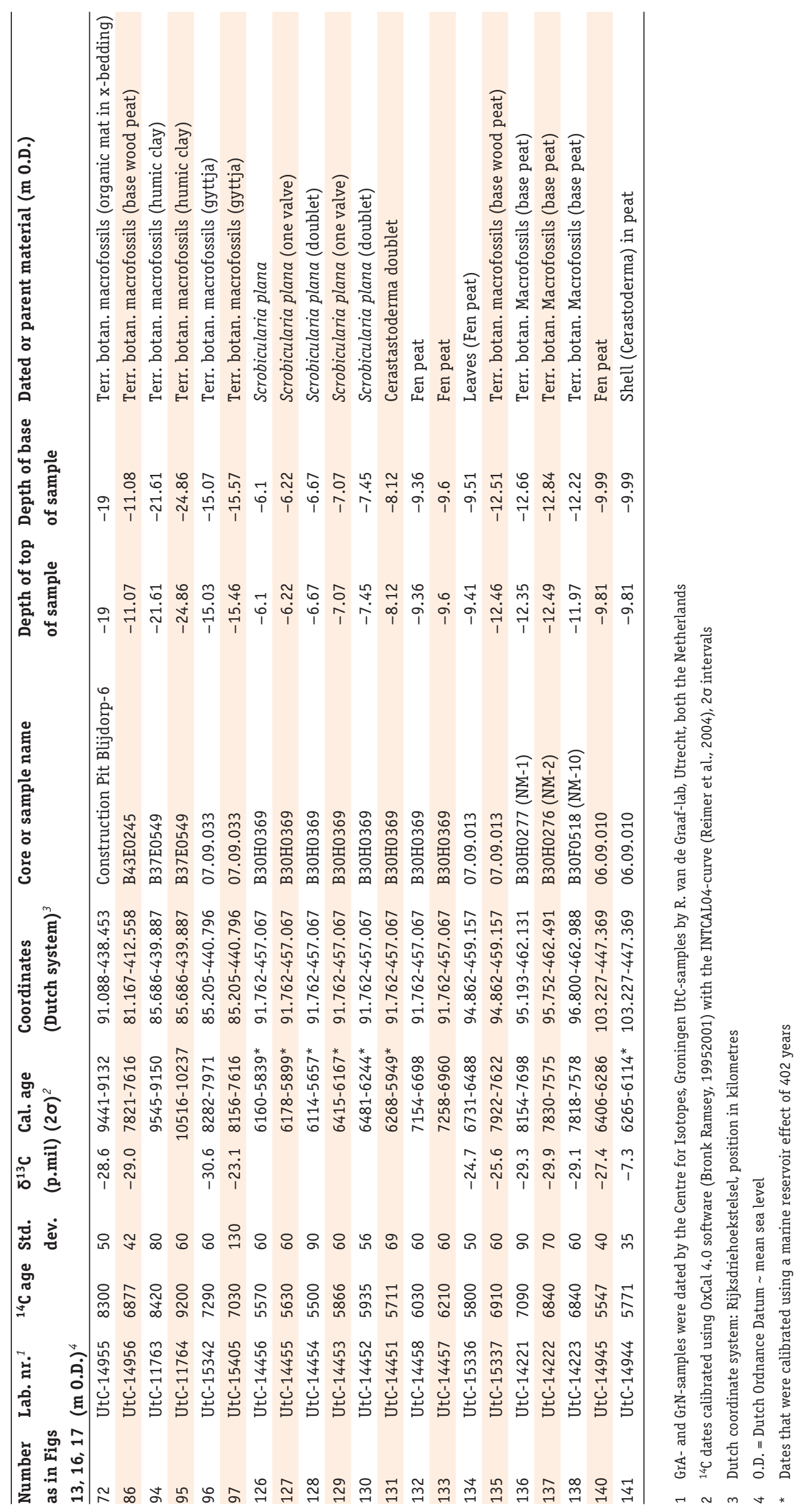


Table 3. OSL dates obtained for this study (see also www.lumid.nl).

\begin{tabular}{|c|c|c|c|c|c|c|c|c|c|c|}
\hline $\begin{array}{l}\text { Number as } \\
\text { in Figs } 13 \text {, } \\
16,17\end{array}$ & NCL code & $\begin{array}{l}\text { Age } \\
\text { (ka BP) }\end{array}$ & $1 \sigma$ & 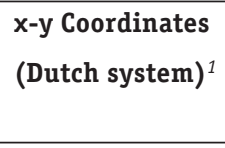 & Core or sample name & $\begin{array}{l}\text { Depth } \\
(\mathrm{m} \mathrm{0.D.})^{2}\end{array}$ & $\begin{array}{l}\text { Dose } \\
\text { rate } \\
(\mathrm{Gy} / \mathrm{ka})\end{array}$ & $1 \sigma$ & $\begin{array}{l}\text { Equiv. } \\
\text { dose } \\
(\mathrm{Gy})\end{array}$ & $1 \sigma$ \\
\hline $\mathrm{a}$ & 4207131 & 8.9 & 0.5 & $103.523-447.586$ & B38A1846 (Waddinxveen) & $-15.73 /-15.83$ & 1.61 & 0.06 & 14.29 & 0.49 \\
\hline $\mathrm{b}$ & 4207132 & 8.1 & 0.4 & $103.523-447.586$ & B38A1846 (Waddinxveen) & $-18.7 /-18.8$ & 1.25 & 0.05 & 10.16 & 0.36 \\
\hline c & 4207133 & 36.0 & 1.9 & $103.523-447.586$ & B38A1846 (Waddinxveen) & $-21.65 /-21.75$ & 1.14 & 0.05 & 40.95 & 1.29 \\
\hline $\mathrm{d}$ & 4207129 & 7.1 & 0.5 & $103.792-452.948$ & B31C1166 (Boskoop) & $-15.3 /-15.4$ & 1.68 & 0.06 & 11.85 & 0.75 \\
\hline e & 4207130 & 8.3 & 0.5 & $103.792-452.948$ & B31C1166 (Boskoop) & $-18.2 /-18.3$ & 1.61 & 0.06 & 13.42 & 0.52 \\
\hline $\mathrm{f}$ & 4207131 & 10.0 & 0.6 & $91.065-438.503$ & Blijdorp OSL 6 & -18.75 & 1.00 & 0.04 & 9.93 & 0.33 \\
\hline g & 4207132 & 8.7 & 0.8 & $91.064-438.505$ & Blijdorp OSL 3 & -20.00 & 1.51 & 0.06 & 13.12 & 1.01 \\
\hline $\mathrm{h}$ & 4207133 & 9.1 & 0.5 & $91.063-438.505$ & Blijdorp 0SL 7 & -21.40 & 1.20 & 0.05 & 10.93 & 0.41 \\
\hline
\end{tabular}

1 Dutch coordinate system: Rijksdriehoekstelsel, position in kilometres

2 O.D. = Dutch Ordnance Datum mean sea level

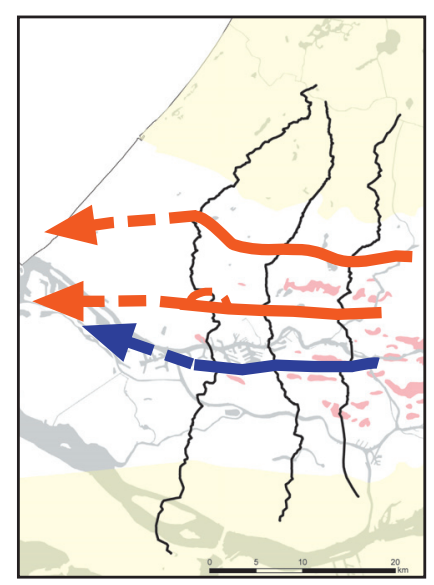

a.

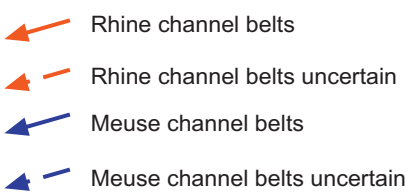

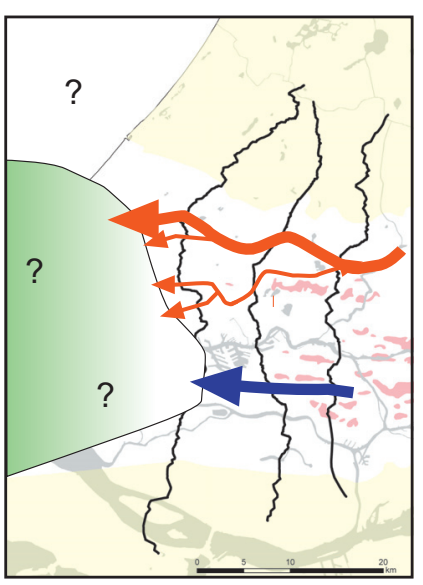

b.

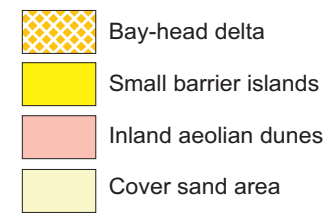

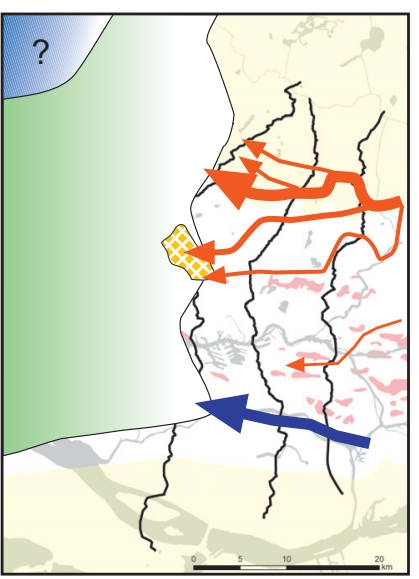

c.

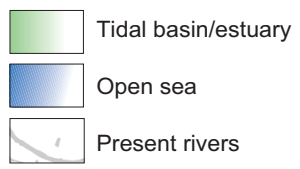

Present rivers

Fig. 15. Schematic palaeogeographic evolution of the western Netherlands during the Holocene transgression. Rhine and Meuse channel belt positions are indicated for five time frames between 9.5 and $6.0 \mathrm{ka}$. a. $9.5 \mathrm{cal} \mathrm{ka} \mathrm{BP}$ (Boreal): two Rhine branches and one Meuse branch flow parallel within Younger Dryas-Early Holocene inherited channel belts. Inland aeolian activity continued; $b .8 \mathrm{cal}$ ka BP (early Atlantic): rivers had transformed to aggrading channel belts, still mainly restricted to the Younger Dryas-Early Holocene inherited incised channel belts. A small connection between the two Rhine branches was established and the southern branch was partially abandoned. The sea transgressed the palaeo-valley; c. 7.5 cal ka BP (middle Atlantic): the Meuse shifted to the south, while the Rhine shifted north. Secondary Rhine branches remained active in central parts of the study area, feeding a bay-head delta (active 8 - $7.3 \mathrm{cal}$ ka BP). Also the northern part of the study area was transgressed; $d .7$ cal ka BP (middle Atlantic): the Meuse remained active in the same area, with a landward migrating mouth. The Rhine discharge shifted further north, establishing the Oude Rijn outlet and abandoning former southerly outlets. Bay-head deltas most likely formed; they were possibly not recognized due to a lack of data and poor preservation. Offshore, embryonic barriers were presumably present; e. 6 cal ka BP (late Atlantic): the Oude Rijn channel belt was formed in the north of the study area. The position of the Meuse did not alter. Transgression halted and the coastline started to progradate.

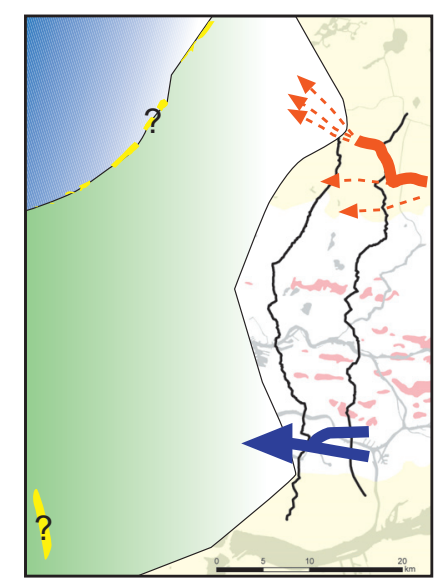

d.

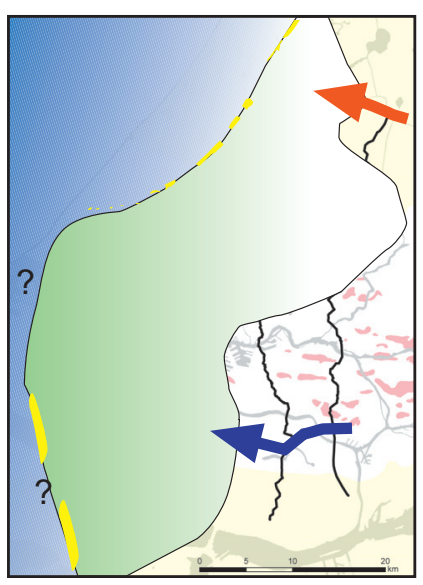

e. 
Carex peat dominates. Between $\mathrm{km} 28$ and $\mathrm{km} 44$ peat formation was quickly halted by marine ingressions. That region became the landward fringe of a tidal flood basin with shallow, brackish open water and tidal flats (H4-6). The associated, mainly clayey, transgressive deposits often erosively overlie the peat with a lag deposit of Cerastoderma and Hydrobia shells (Fig. 11) with wave-action within the tidal flood basin most likely as the erosive agent. The lag is widespread and can be interpreted as a bay ravinement surface (cf. Reynaud et al., 1999). Dates from the shells and the underlying peat yield ages of $6.3-6.2 \mathrm{ka}$ for this subregional ingression $(38,43-46,48,141,142)$. The tidal deposits near km 43 accumulated on an intertidal flat (B31C1166, H-4; diatoms Cymatosira Belgica, Delphineis minutissima and Dryopteris/Chenopodiacaea pollen assemblages). In core B38A1846 (km 35.5; Fig. 11), the base of the tidal sediments ( 9 m -0.D.) was also deposited on an intertidal flat, while palaeo-ecological information from the top layers ( $7 \mathrm{~m}-0 . \mathrm{D}$.) indicate deeper water and a most likely permanently flooded area (H-4).

Small sandy tidal channels were encountered between $\mathrm{km}$ 31 and 34.5 that can be traced to a south-westerly source area in the digital elevation data (Fig. 12). These channels do not connect to the Rijswijk-Zoetermeer tidal system, but probably connect to a tidal inlet west of Rotterdam, i.e. the estuary of the Meuse. In between the two tidal inlet systems, a low tidal watershed must have been present (Fig. 12; further discussed below). In the late Atlantic, the tidal basins started to fill in and widespread peat formation started between 5.5 - $5 \mathrm{ka}$ (Van der Valk, 1996).

Two channel belts at $\mathrm{km} 3$ and 7.3 mark the position of Meuse-branches between 7.5 and $6.5 \mathrm{ka}$. The channel at km 7.3 is the downstream continuation of the Gorkum-Arkel (\#52) channel belt, dated $7.4-6.4$ cal ka BP $\sim 30 \mathrm{~km}$ upstream (Törnqvist, 1993). The other channel presumable links up with the upstream Hill (\#67) Meuse channel belt.

\section{Younger strata (last $5.5 \mathrm{ka}$ )}

During the Subboreal, the position of the Rhine main outlet was very stable. The Meuse debouched into an estuary near Rotterdam, downstream of section A-A'. Outside the channel belts, virtually the whole area had turned into peat land. Peat formation continued until the Middle Ages, when humans started to lower groundwater tables to reclaim arable land and mined the peat for fuel. The latter activity is the cause for the near complete absence of peat between $\mathrm{km} 29$ - 44.5 and surfacing of marine deposits of late Atlantic and early Subboreal age. The Rhine started a stepwise shift of its main discharge towards the Meuse-estuary after $\sim 2$ ka (Berendsen \& Stouthamer, 2000).
The position of the Meuse during the Subboreal and Subatlantic is not obvious from section A-A'. At km 6 it appears that an older channel belt was eroded by the Oude Maas estuary. Also the exceptionally thick channel belt deposits of the Gedempte Devel at km 9 may indicate this channel to have reoccupied an older Meuse channel belt. Alternatively, the thick deposits can be the result of tidal influence or the crosssection passes trough a channel confluence or channel-bend scour where channel belts deposits are naturally anomalously thick (up to five times the average thickness; Ardies et al., 2002).

\section{Cross-section $B-B^{\prime}$}

This cross-section (Figs. 1, 16) is $\sim 57 \mathrm{~km}$ long and based on 236 cores and 270 CPT's. It extends well south of the Late Glacial Rhine-Meuse palaeovalley. The northern end is formed by the Oude Rijn channel belt.

\section{Late Glacial and early Holocene rivers}

South of km 5 and north of km 45, sandy aeolian deposits of Late Glacial age overlie Pleniglacial Rhine-Meuse deposits (Busschers et al., 2007). In between, the Late Glacial-EH palaeovalley surface occurs at depths of 17 to $14 \mathrm{~m}-0 . \mathrm{D}$. North of km 14, it is overlain by the WM; to the south this member is absent. Between km 27 - 28, 29 - 32 and north of km 35 the WM is also absent. This marks the position of the Rhine channel belts during the Late Glacial-EH (HR-d; WR-a/HR-a; HR-b, WR-b, $\mathrm{HR}-\mathrm{c})$. At $\mathrm{km} 39.5$, a dated peat bed provides a minimum age for abandonment of WR-b ( 9.5 ka, 78). Near km 18, a marked step in the elevation of the top of channel belts deposits $(\sim 16 \mathrm{~m}$ -0.D.) is visible, which is mimicked in overlying deposits. This step is a candidate marker of a neotectonically active fault, suspected to border the WNB (Fig. 1). The EH Meuse channel belt (HM-a) was most likely positioned near $\mathrm{km} \mathrm{17,} \mathrm{where} \mathrm{the}$ most southerly and earliest aggrading channel belts have been recognized.

At several locations aeolian river dunes were encountered. At $\mathrm{km} \mathrm{1,} \mathrm{an} \mathrm{isolated} \mathrm{dune} \mathrm{is} \mathrm{observed} \mathrm{well} \mathrm{within} \mathrm{the} \mathrm{cover} \mathrm{sand}$ area. In the Rhine-Meuse palaeovalley, a dissected complex of relatively low dunes is present within the stretch $\mathrm{km} 17-29$. Dated plant remains in cross-bedded deposits underneath an aeolian dune (72) give ages of 9.4 - 9.1 ka. A humic layer in a small residual channel that dissects the dune has an age of $\sim 9.4-9.0 \mathrm{ka}$ (71). This constrains the age of this particular dune to $\sim 9.2 \mathrm{ka}$ (Cohen \& Hijma, 2008). Dates 57 - 60 constrain the formation of the dune near $\mathrm{km} 27$ to the late Boreal-early Atlantic. Between km 41 - 42, fringing the HR-c channel belt, a 

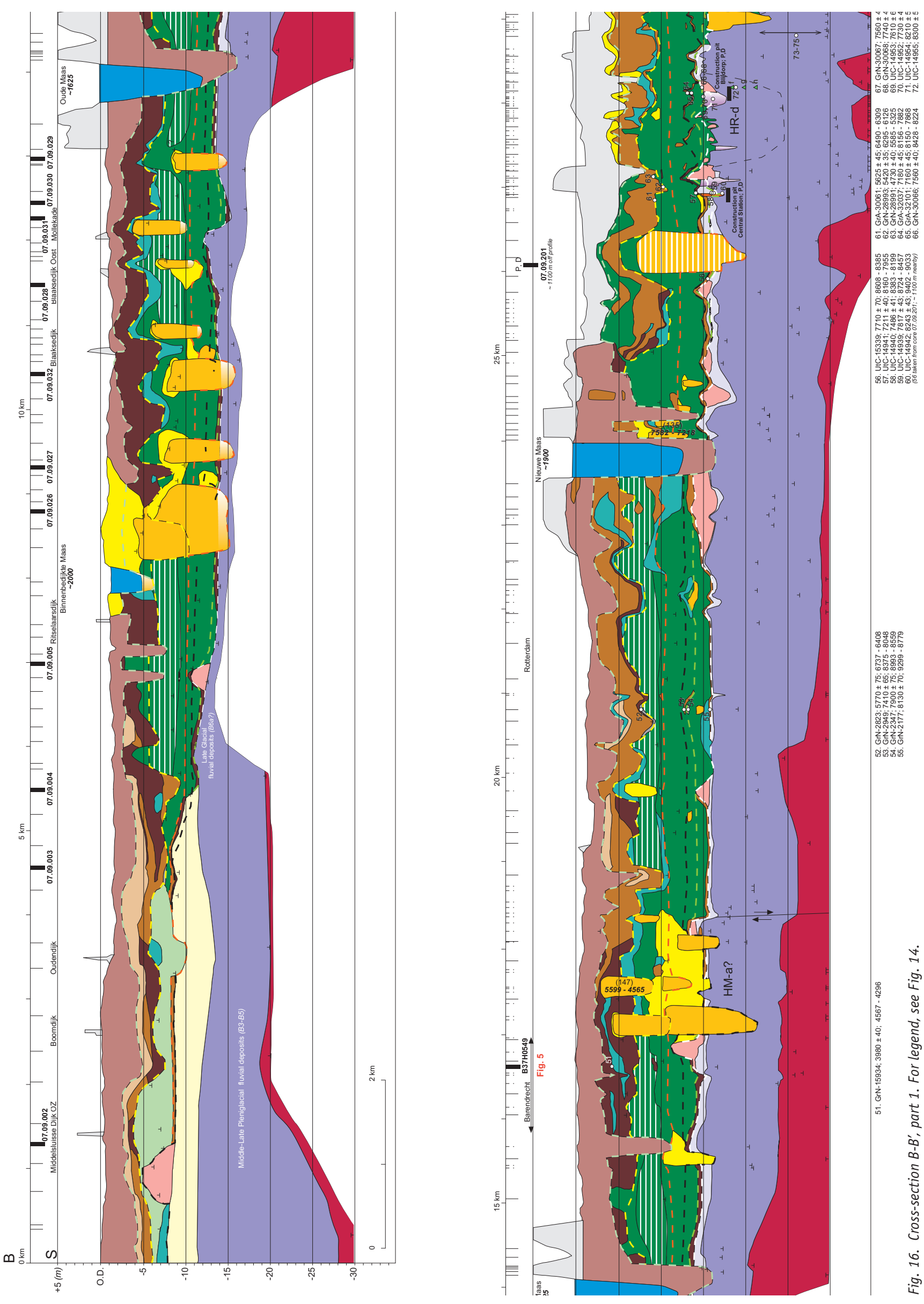

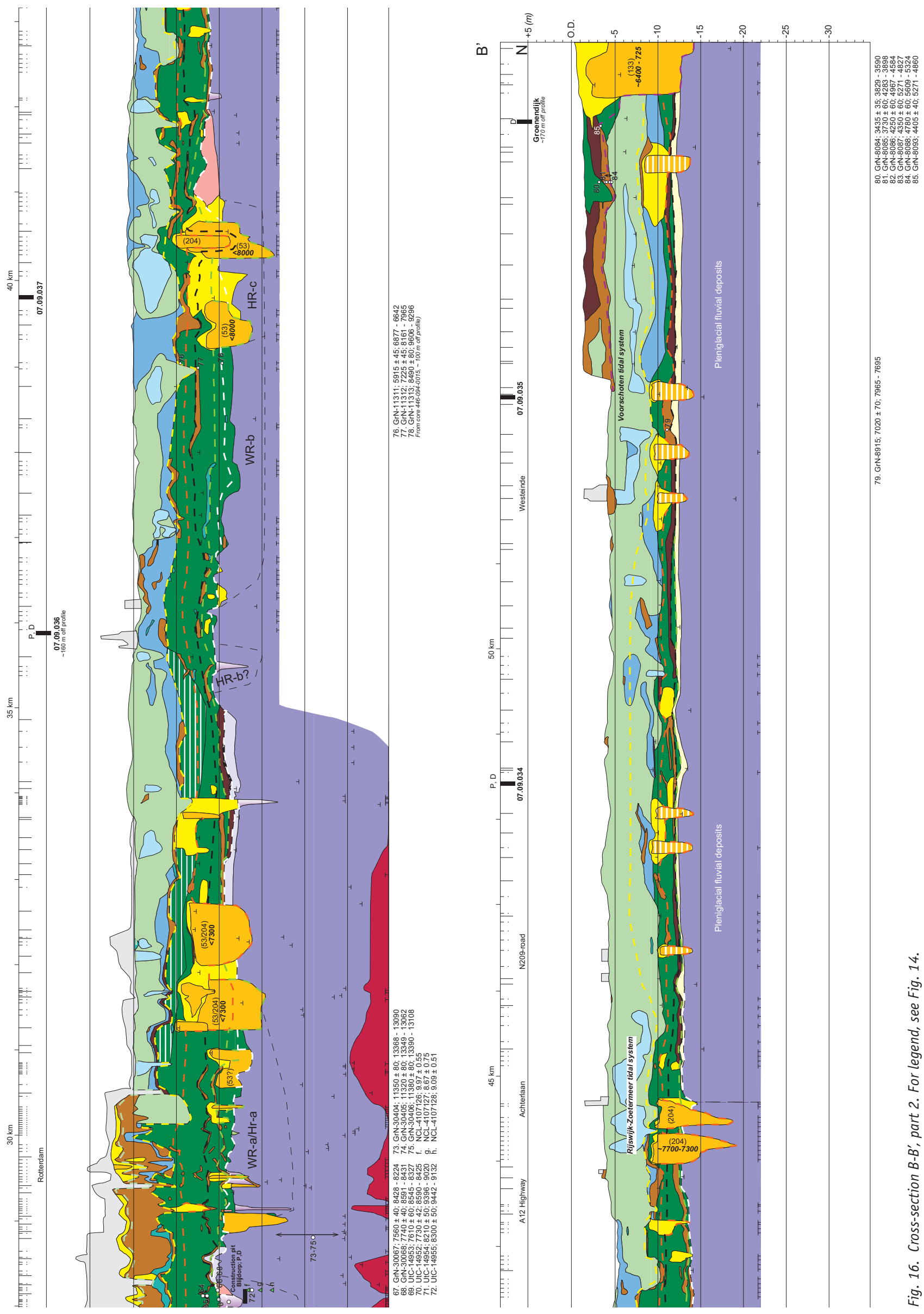
flat sand body is present with a decalcified top. We interpret it as a dune, formed at the northern limit of Late Glacial/EH Rhine activity.

Evidence for earliest, slightly aggrading rivers was found in a construction pit in Rotterdam (km 27 - 29; Cohen \& Hijma, 2008). The top of the channel belt deposits (HR-d) undulates irregularly in this area, but is on average somewhat higher than the older channel belt surfaces to the north. OSL $(f-h)$ and radiocarbon (72) dates show the channel to have been active in the Boreal. To the south of HR-d, the thickness of the WM decreases significantly. A peat layer on top of a distal part of the WM has been dated $\sim 9 \mathrm{ka}$ (55), a terminus ante quem for the abandonment of HR-d. Given its northward position, HR-d probably belonged to the Rhine-system. Closer to the channel basal peat formation started at $\sim 8.5 \mathrm{ka}(59,69,70)$. Pollen and diatom analysis of this layer indicate shallow standing water (epiphytic diatoms) with abundant water plants (Nymphaeaceae), no tidal and little fluvial influence (H-4).

\section{Atlantic aggradation}

Channel belts at km 30 - 32.5 and km 39 - 41 mark the position of the main Rhine-branches between 8.5 - $7.7 \mathrm{ka}$. The channel belt deposits are stacked and have thick natural levee deposits. Between the belts widespread peat formation started just before $8 \mathrm{ka}(53,57,64,65,77)$. Upstream avulsions (see description of section A-A') led to the formation of the channel belts (\#204) at $\mathrm{km} 44.5$ and gradual abandonment of channel belt \#53 to the south; the avulsion was completed $\sim 7.3 \mathrm{ka}$. Pollen and diatom analyses on core 07.09 .036 ( $\mathrm{km} \mathrm{36}$; interval 13/10 m -0.D.) indicate a fresh water flood basin with some tidal influence towards the top (H-5, H-6). Near km 48.5 (core 07.09.034), diatom (Cocconeis placentula, planctic species) and pollen (Nymphaeaceae) analyses show that below $11 \mathrm{~m}-0 . \mathrm{D}$. deposits accumulated in a fresh, standing water environment ( $\mathrm{H}-5$, $\mathrm{H}-6)$. At $10.5 \mathrm{~m}-0 . \mathrm{D}$., the abundance of river transported palynomorphs can be related to $7.7-7.3 \mathrm{ka}$ avulsion events that routed river discharge into this area. Above $9.5 \mathrm{~m}-0 . \mathrm{D}$., sedimentation occurred in a tidal environment, with initially still fresh, but increasingly more salt water environments (H-5, $\mathrm{H}-6)$. The small and heterolithic (sand-clay) channel belts at $\mathrm{km} 52$ - 56 are most likely the downstream continuations of channel \#177 in cross-section A-A'. The initiation of channel \#133 (Oude Rijn) and the abandonment of channel \#177 seem to coincide with the formation of the Voorschoten tidal system (km 53, 134 in cross-section C-C') within the former mouth of channel \#177. Estuarine conditions near channel \#133 are evident from diatom analysis (H-27; km 56; 9 - 5 m -0.D.), revealing sandy intertidal flat environments with a nearby estuary. After progradation of channel \#133 had begun (see description Fig. 13 ), widespread peat formation started $\sim 5.2 \mathrm{ka}$.

Between km 9.5 - 14 multiple small channels with top-ofchannel deposits between 9 and $4.5 \mathrm{~m}-0 . \mathrm{D}$. suggest this to have been an anastomosing part of the fluvial delta. Based on depth-position, three generations can be distinguished, that most likely are linked to the upstream Gorkum-Arkel (\#52) channel belt system (Berendsen \& Stouthamer, 2001). The main Meuse channel belt was situated at $\mathrm{km} 8$ - 9. As in section A-A', flood basin deposits in between the Rhine-Meuse channels ( $\mathrm{km} 6$ - 36, around $9 \mathrm{~m}-0$. D.) are strikingly homogenous in build up (Terbregge Mb., Fig. 5). They date to $7.5-6.5 \mathrm{ka}$. Near the centre of Rotterdam and north of $\mathrm{km} \mathrm{36}$, the presence of the TM is not clear due to a lack of detailed corings. North of $\mathrm{km} \mathrm{36}$, phragmites fragments seem to occur more frequently instead of woody debris. At $\mathrm{km} 26$ a fluvial-tidal channel is present, analysed in detail in core 07.09.201, some $700 \mathrm{~m}$ upstream of the line of section. Diatom and pollen analyses $(\mathrm{H}-4, \mathrm{H}-6)$ show that despite the tidal sedimentary signature, fresh water conditions prevailed. This is also evident from the composition of surrounding fresh water peats.

\section{Younger strata (last $5.5 \mathrm{ka}$}

Besides a small corridor occupied by a main Meuse channel $(\mathrm{km}$ 8 - 9), widespread peat occurence over the southern 30-km of the section shows the existence of a large swamp after $6.5 \mathrm{ka}$. At km 8 - 9 a stacked channel belt complex marks the position of the main branch of the Meuse-estuary until the Oude Maas (\#132) channel belt was formed in post-Roman times. The channel belt complex can be connected upstream to the severely eroded Meuse-system at km 6 in Fig. 13 and was most likely at some point also linked to channels at $\mathrm{km} 4$ and $\mathrm{km} 7.5$ in that same cross-section. South of $\mathrm{km} \mathrm{7,} \mathrm{salt} \mathrm{marshes} \mathrm{were} \mathrm{present.}$ To the north, widespread peat formation started between $6.5-5.5 \mathrm{ka}$. Over most of the section peat formation appears to have started before $6 \mathrm{ka}$, simultaneous with the onset in Figure 13. North of $\mathrm{km} \mathrm{18,} \mathrm{phragmites} \mathrm{peat} \mathrm{was} \mathrm{formed} \mathrm{instead} \mathrm{of}$ wood peat. Further developments as in Fig. 13.

\section{Cross-section C- $C^{\prime}$}

This cross-section (Figs 1, 17) is $73.5 \mathrm{~km}$ long and is based on

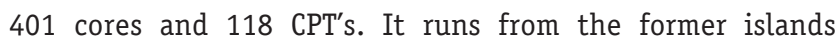
Goeree-0verflakkee in the south to the Oude Rijn channel belt in the north. 


\section{Late Glacial and early Holocene rivers}

Between km 11 and 53, the Late Glacial-EH valley floor is situated at depths of 16 to $21 \mathrm{~m}-0 . D$. To the south and north, the Holocene succession overlies Pleniglacial deposits situated 3 to $5 \mathrm{~m}$ above the Late Glacial Rhine-Meuse palaeovalley. Near $\mathrm{km} 8$ - 9 a depression is observed within the Pleniglacial deposits, filled with fluvial deposits with a more local signature (18 - $14 \mathrm{~m}$ -0.D.), which may indicate that the valley of a local tributary was crossed here (e.g. the Late Glacial river Mark). Over most of the section, the valley floor is capped by the WM Where it is absent, the top of the channel belts shows undulations of $1-2 \mathrm{~m}$ amplitude, depicting the original river bed relief. Note that observation-density varies strongly along the section, allowing to resolve palaeovalley topography in detail for parts of the section only. Late Glacial-EH Meuse activity was concentrated between km 23 - 27.5 (WM-a/HM-a), while the Rhine was mainly active within two channel belts (km 29 - 32: WR-a/HR-a; km 36 - 41: WR-b/HR-b/c). A considerable part of the deposits mapped as the WM have been supplied by channel belts HM-a and HR-a/b/c.

Near km 37.5 a marked step in elevation is visible in the top sandy channel belt deposits (19 m -0.D.) and overlying deposits. The step is of similar magnitude as observed at km 18 in Figure 16 and is a candidate marker of a neotectonically active fault running ESE-WNW. This direction matches that of faults bounding the WNB in the deeper subsurface. In Figure 1 the inferred fault zone is indicated.

At Schiedam (km 35) a remarkably deep ( $19 \mathrm{~m})$ and relatively narrow entrenchment is present below $18 \mathrm{~m}-0 . \mathrm{D}$. The infill consists of late Preboreal-Boreal fresh water clays (De Groot \& De Gans, 1996; Busschers et al., 2005), suggesting that the entrenchment occurred in the Preboreal. It probably represents a final phase of activity of channel belt HR-a, that in the Late Glacial had reworked the zone between km 29 - 31, while shifting northwards laterally. Channel belt activity between km 29 - 31 must have ended in the Preboreal, as the area was subsequently covered by thick WM deposits.

In the WNB the basal peat on top of the WM has been dated $\sim 9.4-9.0 \mathrm{ka}(98,111,146)$. On the southern block two dates south of $\mathrm{km} 29$ give younger ages of $\sim 8.8 \mathrm{ka}(92,93)$, suggesting that peat formation started earlier in the WNB than on the southern block due to lower elevations (relatively more subsidence). More dates are needed to resolve this issue. Buried inland dunes occur between $\mathrm{km} 27$ - 33, adjacent to $\mathrm{EH}$ channel belts (HM-a and HR-a) and overlying the WM.

At km $23-27.5$, a Meuse channel belt is present. About 500 $\mathrm{m}$ upstream of the line of section (core B37G0548), a clastic channel fill within this channel belt was described ( $\mathrm{H}-1$, see also Busschers et al., 2007). The base of the fill has been 0SLdated at $10-11 \mathrm{ka}(\mathrm{n}, 0)$; a peat at the top of the fill at $\sim 8.8 \mathrm{ka}$ $(92,93)$. The youngest phase, HM-a, is probably situated at $\mathrm{km}$ 26 - 27.5, because there the WM appears absent.

\section{Atlantic aggradation}

In Section C-C' aggradation started shortly after $~ 8.7 \mathrm{ka} \mathrm{(92,}$ 93). On the higher elevated cover sand areas, aggradation did not start before $7.7 \mathrm{ka}(86,136,138)$. The oldest aggrading Rhine channel belts are situated at $\mathrm{km} \mathrm{30.8,} \mathrm{km} \mathrm{36,} \mathrm{km} 44$ and $\mathrm{km} 47$ and have their top at $15 \mathrm{~m}-0 . \mathrm{D}$. Their associated overbank deposits consist of sandy, light gray clays with horizontal layers of predominantly fine sand, possibly indicating tidal influence. Occasionally, layers of coarser sand are encountered (Fig. 6). Near km 37 a natural levee is capped by fen wood peat dated to $\sim 8 \mathrm{ka}$ (103). Several small channel belts near km 24 (15 $\mathrm{m}$-0.D.) indicate the earliest aggrading Meuse channel belts.

North of km 29, fluvial-tidal flood basin deposits (TM) are encountered between 12 - 9 m -0.D. An incorporated thin layer of clayey wood peat (possibly a strongly rooted soil horizon) between km 35 - 38 was dated 7.3 ka (102; Fig. 9). Between $\mathrm{km} 26$ - 29 the presence of the TM is not clear. Between km 29 - 31 the amount of wood fragments is lower than to the north, but still indicates steady fluvial supply. This changes abruptly south of $\mathrm{km} \mathrm{26}$, where extensive laminated heterolithic bedding (clay-sand) is observed (Fig. 10), associated to the large estuarine Meuse channel system (km 16 - 20), that most likely was formed $\sim 7.3 \mathrm{ka}$ after a landward shift of the estuary due to the northward shift of the main Rhine-branches (see description Fig. 13). The channel belt at km 15 presumably positions the Meuse just before this occurred. To the south of the estuarine channel, extensive tidal flat deposits are present that overlie $\sim 0.5$ - $1 \mathrm{~m}$ of fresh water clay containing many Salix leafs. The associated fresh flood basin first turned into a supratidal salt marsh (12 $\mathrm{m}-0 . \mathrm{D}$.) and then rapidly into an intertidal flat, amongst others supported by diatom assemblages (H-5) indicating a marine ingression. The intertidal flat deposits consist of fining upward clay-sand alterations with Hydrobia and Cerastoderma shells. Median grain sizes are smaller than $100 \mu \mathrm{m}$. Towards the top ( 3 to $5 \mathrm{~m}-0 . \mathrm{D}$.) marine influence decreased rapidly and fresh swamp vegetation returned (H-6) under the influence of nearby Meuse-branches (Verbraeck \& Bisschops, 1971). The muddy intertidal flat deposits south of km 2 mark the edge of the Atlantic Meuse estuary.

Several Rhine-branches debouched in the Delft area in the early Atlantic (km 36 - 46). Overlying and underlying peat beds, 


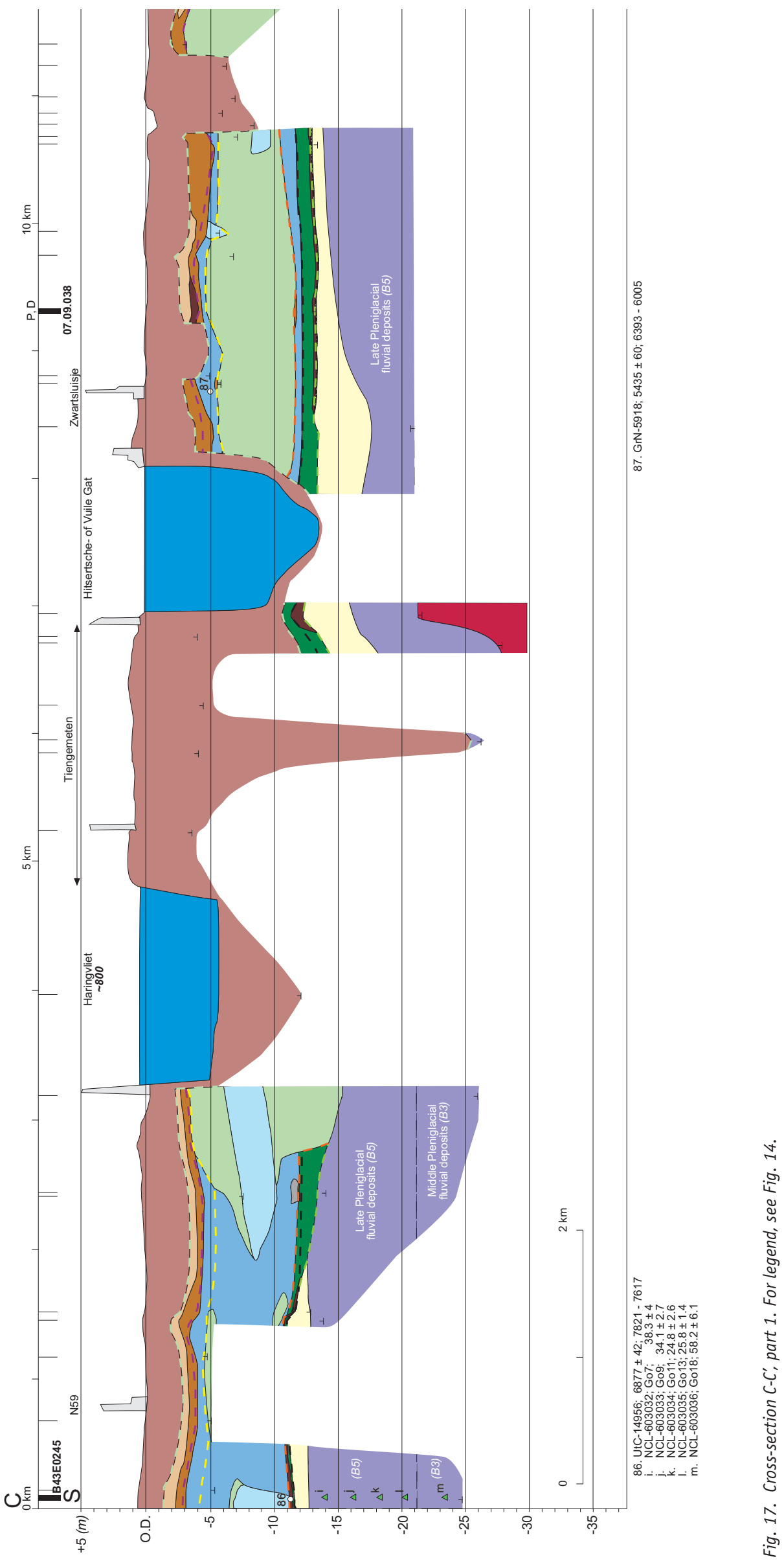

Netherlands Journal of Geosciences - Geologie en Mijnbouw | 88 - 1| 2009 


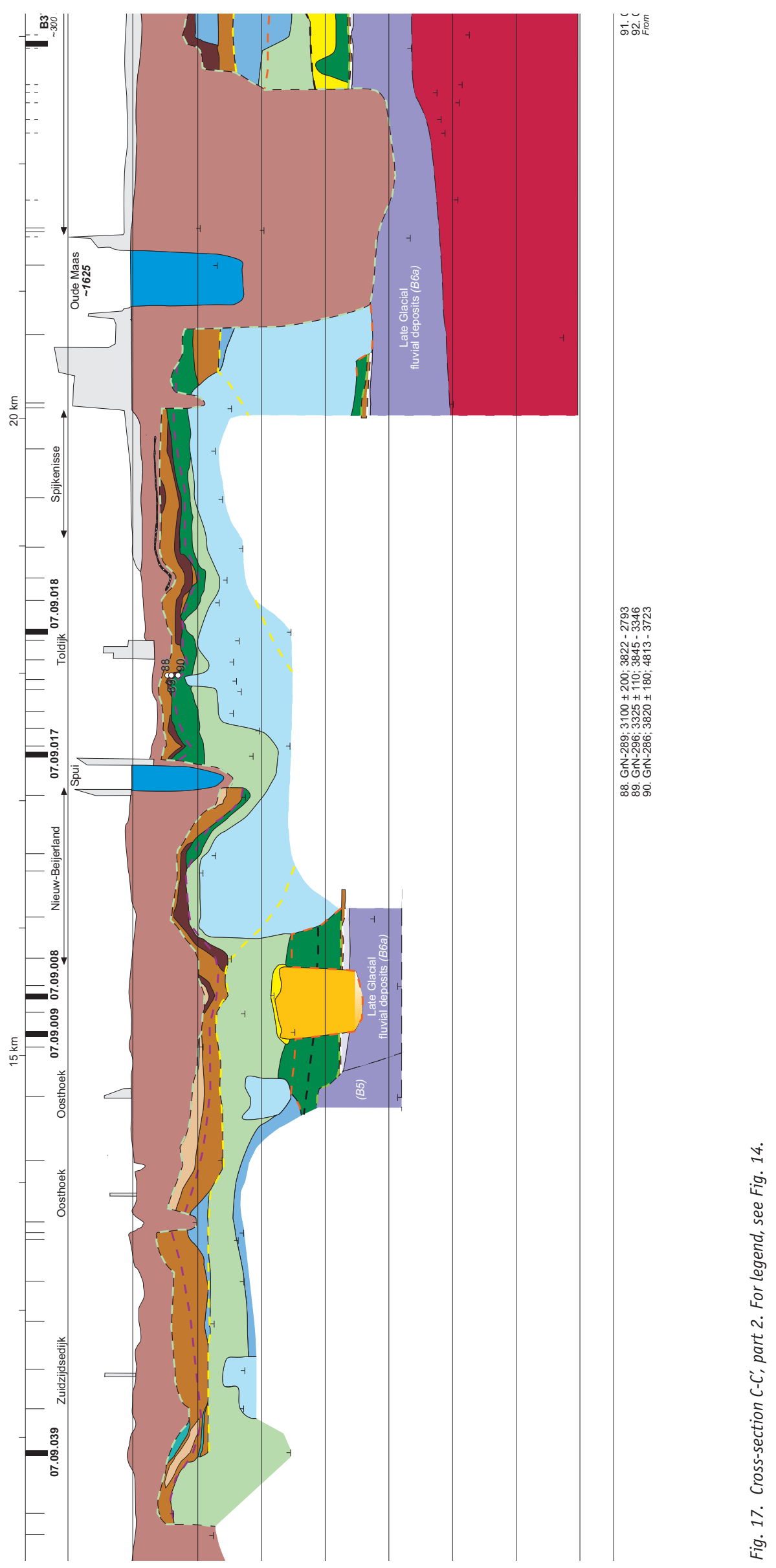




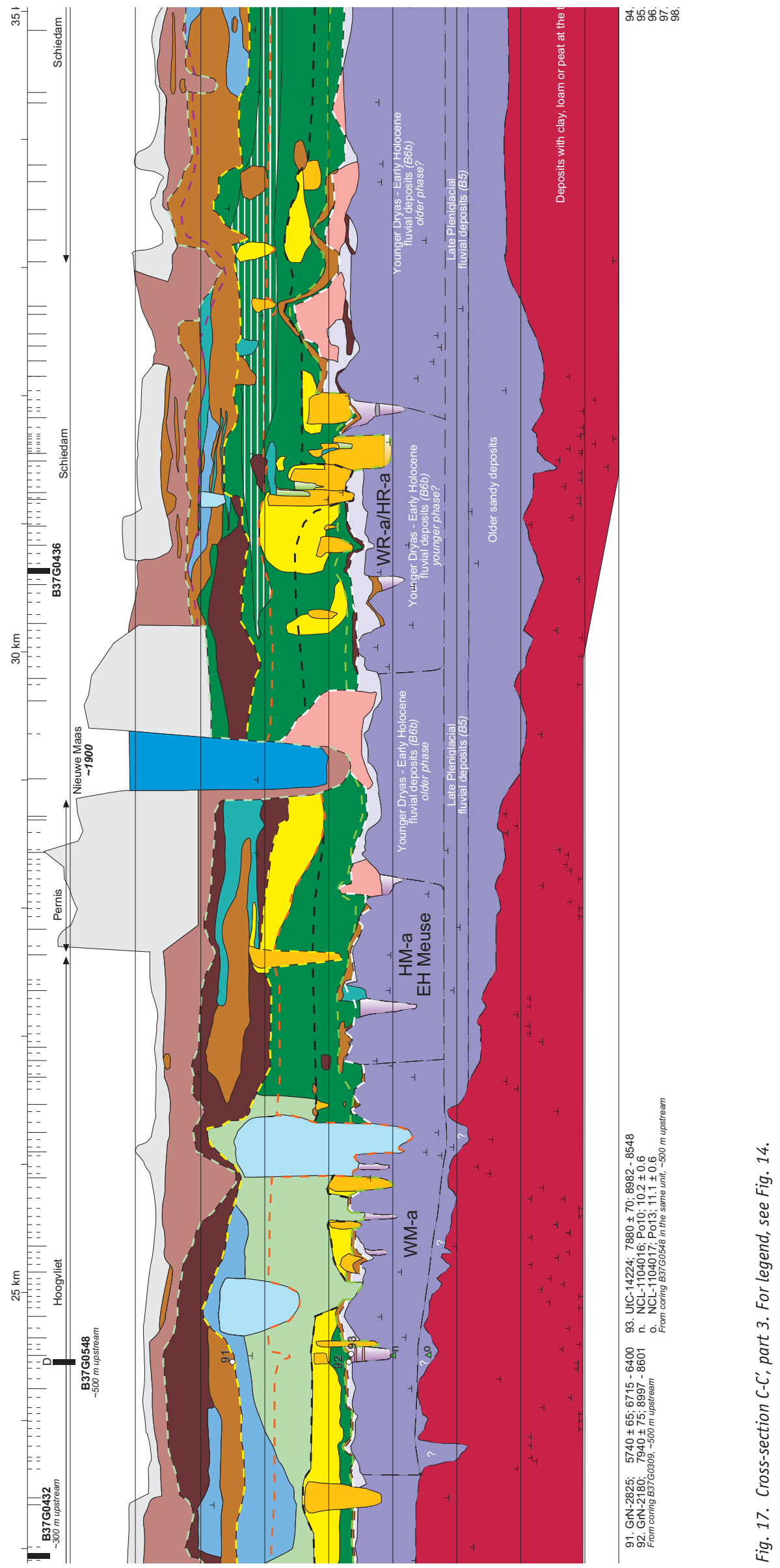

Netherlands Journal of Geosciences - Geologie en Mijnbouw | 88 - 1| 2009 


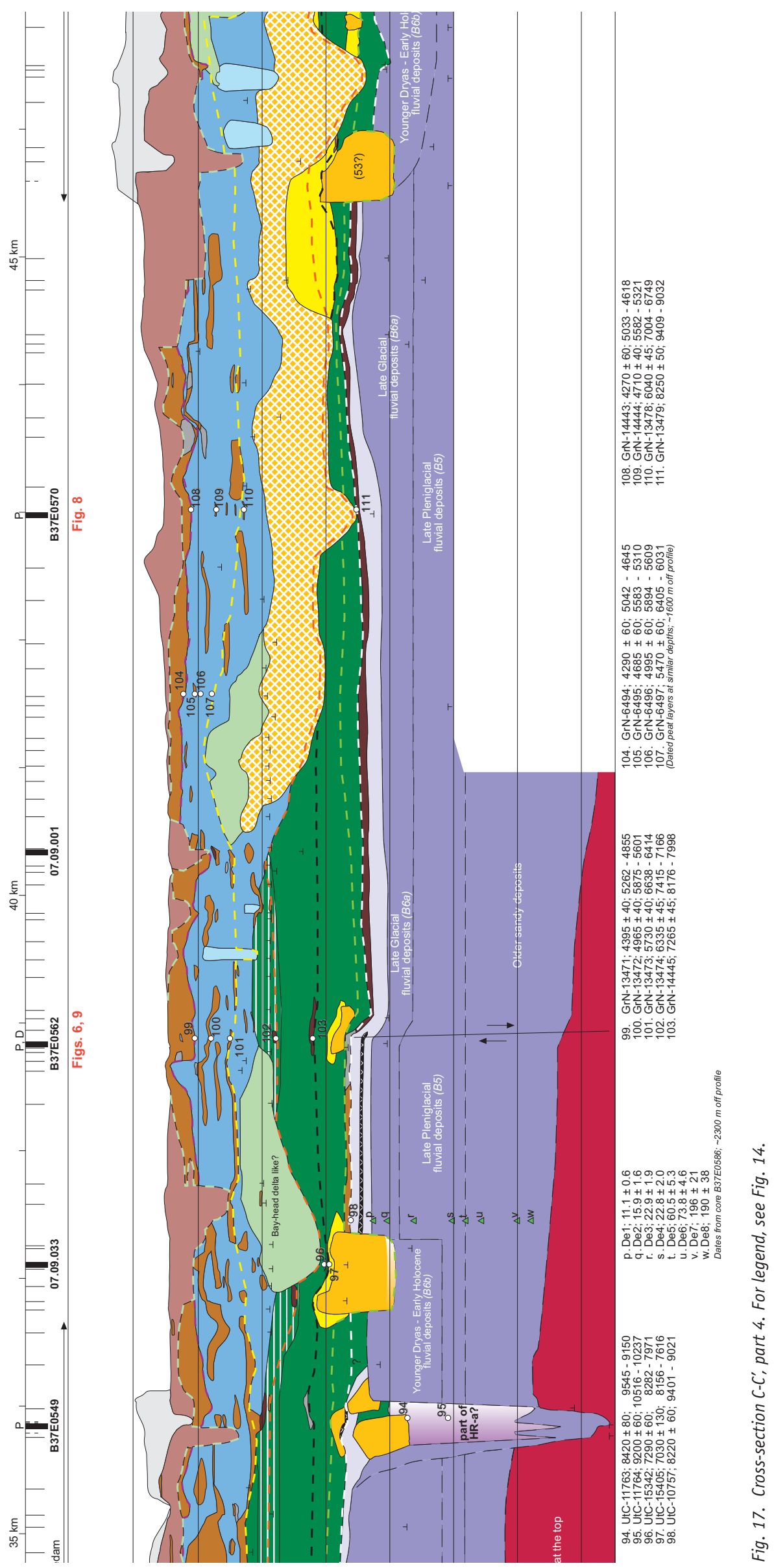




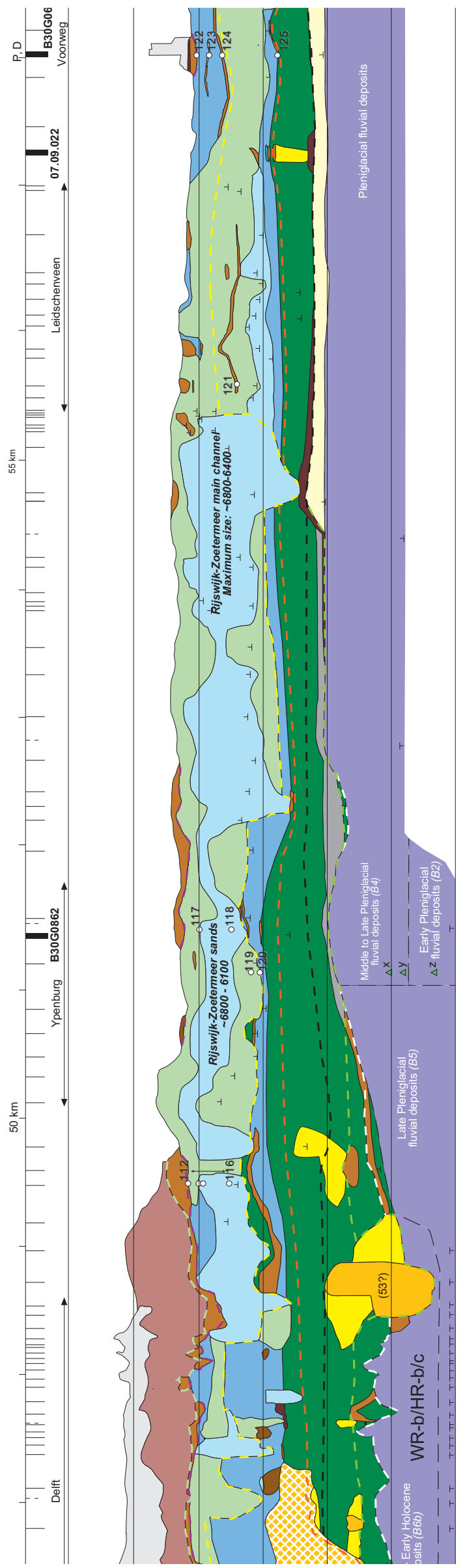

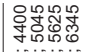

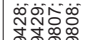

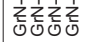

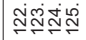

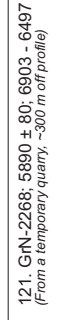

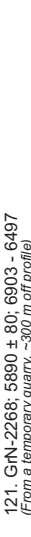

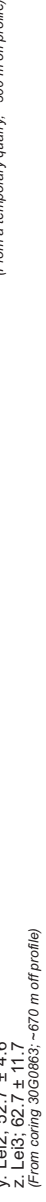

年

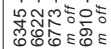

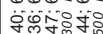

+1+1+in

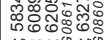

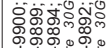

5 .

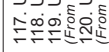

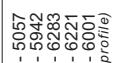

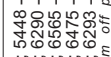

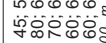

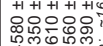

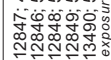

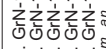

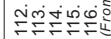

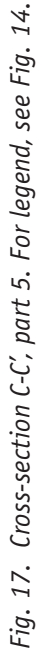




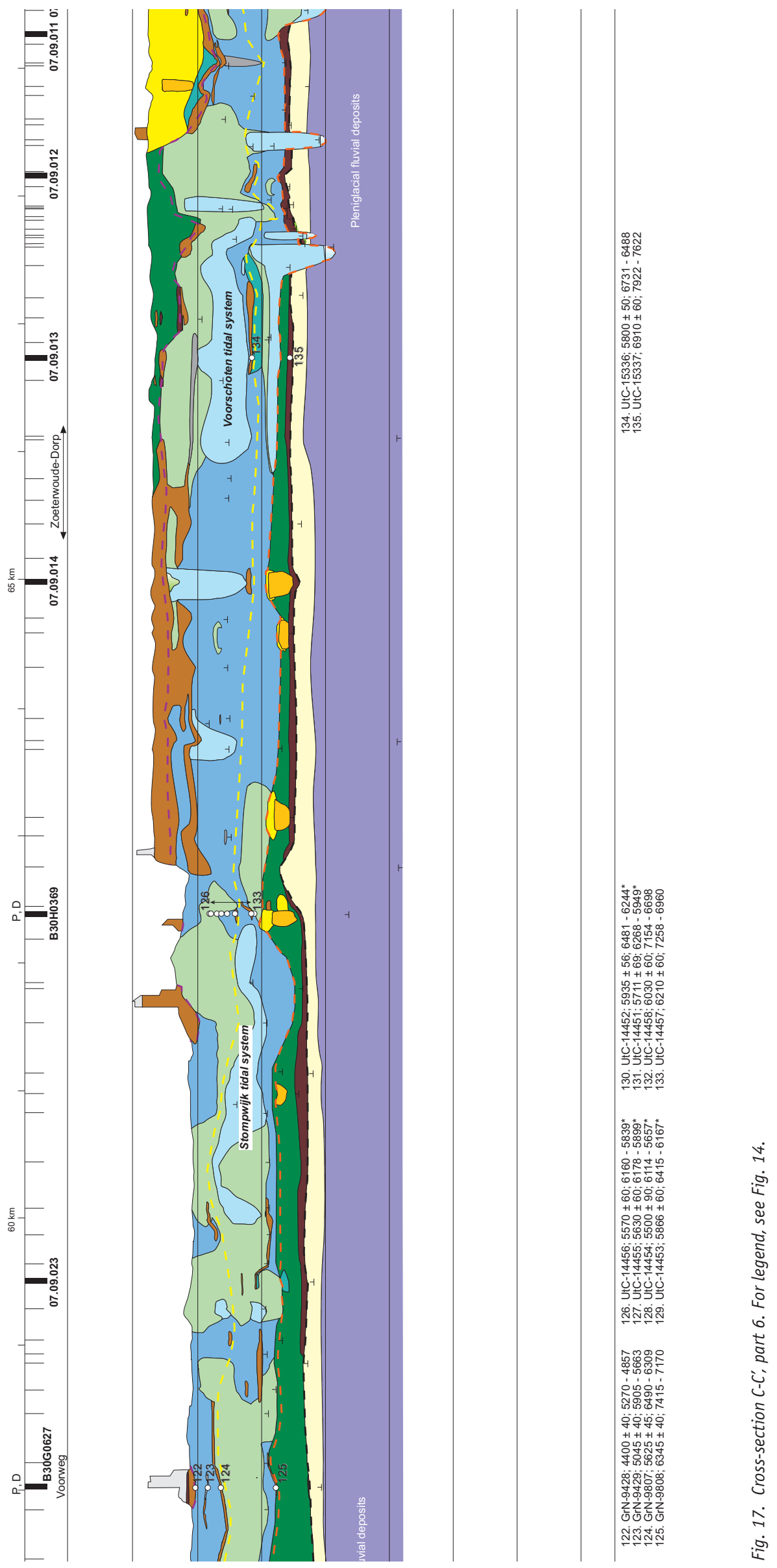


as well as dates on upstream connections, constrain significant delivery of Rhine discharge to 8.0 - $7.3 \mathrm{ka}$. A 3 - $4 \mathrm{~km}$ wide and relatively thick sandy body (here after named Delft sands) is present between $\mathrm{km} 39$ and 46 at depths of 9 to $15 \mathrm{~m}-0 . \mathrm{D}$. (maximum thickness $\sim 7 \mathrm{~m}$; average thickness $\sim 4-5 \mathrm{~m}$, appears longer in cross-section than in plan view). The top consists of very fine sands $(110-150 \mu \mathrm{m})$ and the sands contain frequent clay laminations and organic detritus, occasional beds of coarser sand and shell fragments (Fig. 8). This sandbody is interpreted to represent a bay-head delta (as in Fig. 7, fully treated in the discussion section; for location see Fig. 15). The bay-head delta can be connected to upstream channel belts \# 53/204 (km 32 and 41, Fig. 16). Fresh water conditions at this position during this time are evident from vivianite stains and diatom analysis (H-3; below $10.5 \mathrm{~m}-0 . \mathrm{D}$. at km 61). The bayhead delta was abandoned following the 7.3-ka avulsion that established channel belt \#177 (see description of Figure 13). In the former bay-head delta area a shallow tidal basin existed afterwards that silted up rapidly and discontinuous peat formation started after $\sim 6.9 \mathrm{ka} \mathrm{(110).}$

Narrow tidal channel belts at km 65.5 - 68 (9 m -0.D.) presumably link up to channels at km $45-49$ in Fig. 16 and if so were active after $7.3 \mathrm{ka}$. The sandy tidal channel deposits flanking the southern edge of channel belt \#133 (km 72.5,
6 - $12 \mathrm{~m}$-0.D.) suggest that channel belt connected to an existing tidal channel system. Between km 46 - 70 complex tidal systems developed, starting subsequently after $7.5 \mathrm{ka}$ (125). The largest tidal inlet, the Rijswijk-Zoetermeer system at $\mathrm{km} 50$ - 54, had its maximum size between $\sim 6.8$ and $6.4 \mathrm{ka}$ and closed around $6.1 \mathrm{ka}$ (Van der Valk, 1996; Cleveringa, 2000; see also 119, 120,124, 125). Sandy deposition of the Stompwijk tidal system ended also around $6.1 \mathrm{ka}$ (131). The sandy deposits between km 46 - 50 are part of the RijswijkZoetermeer sandsheet (succession back-barrier to beach plain deposits) that formed between 6.7 - $6.3 \mathrm{ka}$ (Van der Valk, 1996; Cleveringa, 2000; Van der Spek et al., 2007). Date 134 seems to indicate that the Voorschoten tidal system had its maximum activity after $6.4 \mathrm{ka}$. This is probably related to the disappearance of the Waddinxveen channel belt, allowing tidal channels to penetrate further landward. North of the Rijswijk-Zoetermeer tidal inlet, diatoms in core B30H0369 (km 62.4) indicate brackish lagoonal sedimentation for the 8 and $6 \mathrm{~m}-0 . \mathrm{D}$. interval, dated at $\sim 6.3$ - $6 \mathrm{ka} \mathrm{(126} \mathrm{-} \mathrm{131).} \mathrm{After} 6 \mathrm{ka}(126)$, marine influence increased and the area became part of an intertidal zone (H-3) within the estuarine outlet of channel belt \#133. The sandy deposits of the closed Rijswijk-inlet probably formed a modest topographic high for some time due to less compaction than surrounding peats and clays. This high might have separated

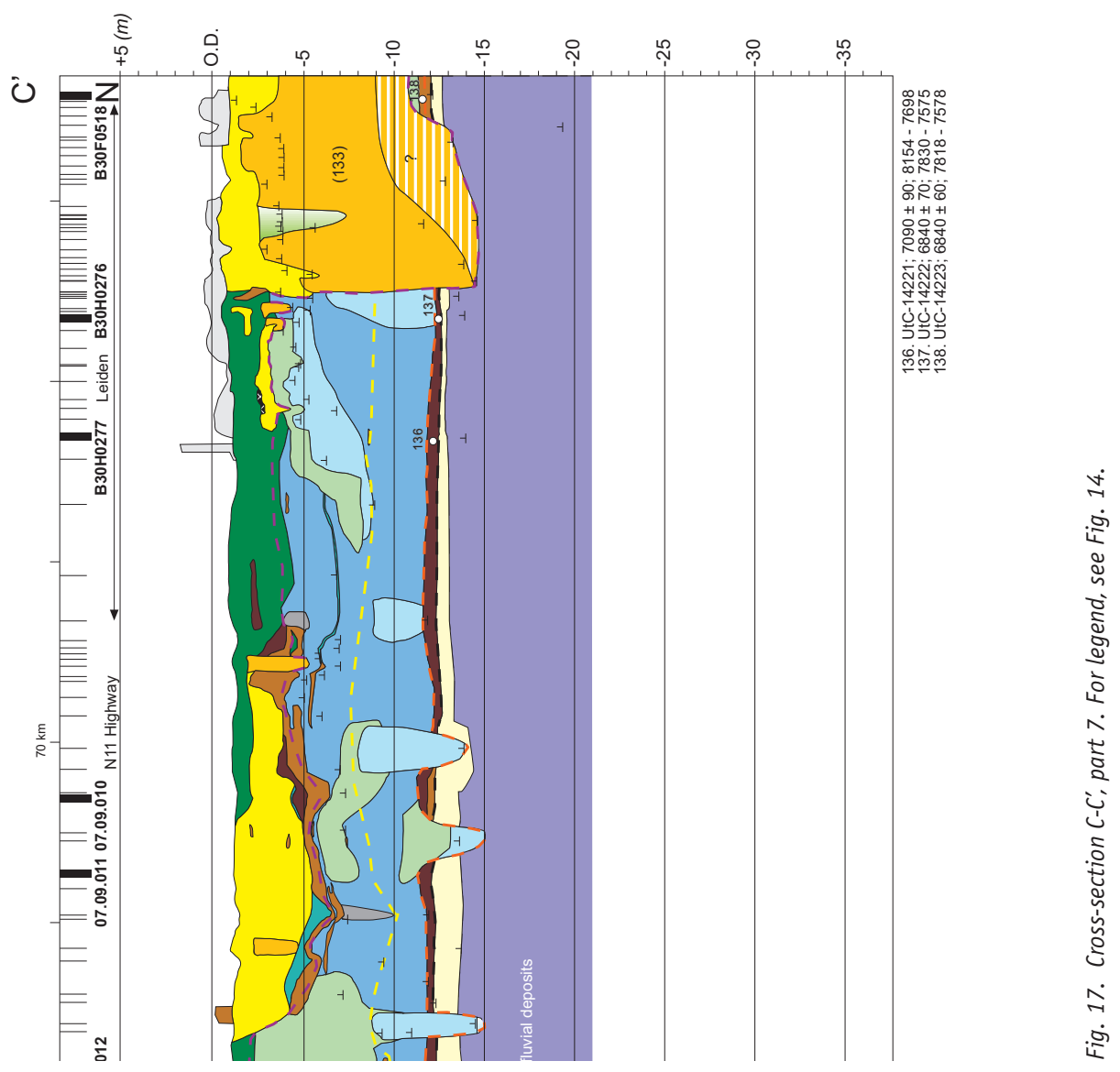


the Oude Rijn and Meuse-estuaries (Fig. 12). Between km 34 - 45 mainly clay was deposited between 6.5 - $5 \mathrm{ka}$ (99 - 101, 104 - 106, 108 -110). The area was probably part of the Meuse-estuary. At the base, diatoms indicate sub- to intertidal conditions (species Cyclotella striata, Cymatosira belgica, Cocconeis diminuta) with fresh admixtures suggesting the presence of a nearby river mouth (H-30, H-31), possibly reflecting the Meuse to the south. To the top, the environment gradually changed to a supratidal salt marsh (Diploneis interrupta, Nitzchia navilcularis, Rhoicosphenia curvata) with occasional phases of freshening (H-30, H-31).

\section{Younger strata (last $5.5 \mathrm{ka}$ )}

After $\sim 5$ ka peat formation started and continued until the Middle Ages. Between km 22 - 34 large scale peat formation already started $\sim 6.5 \mathrm{ka}$ (91). Between $\mathrm{km} 48$ - 61 the peat was removed by humans. North of $\mathrm{km} 64$ peat could not form due to sedimentation of the Oude Rijn. The Meuse shifted north to the area of the present Oude Maas. The abandoned Meuse-estuary (km 16 - 20) silted up above its surroundings. Consequently, peat formation started to bury this abandoned estuary relatively late, around $\sim 4.5 \mathrm{ka}$ (90). South of the $\mathrm{km} 16$ peat formation started after $\sim 6.2 \mathrm{ka}$ BP (87). Peat formation continued into Subboreal times and eventually caused oligotrophic raised bogs to develop on top of eutrophic lagoonal peat in large parts south of km 16. Subatlantic developments match those described for Fig. 16.

\section{Discussion}

\section{Earliest Holocene fluvial evolution}

\section{The Wijchen Member in the western Netherlands}

The WM comprises overbank deposits of Late Glacial and in particular EH Rhine-Meuse channels (H- and R-channels, Figs $13,16,17)$. This is evident from its thickening in the vicinity of these channel belts. In the study area, the bulk of the WM was deposited during the EH (Busschers et al., 2007; this paper). Dark floodplain palaeosols occur in the top of the WM (e.g. Törnqvist et al., 1994; Autin, 2008). In some parts of the study area, especially in the NE near EH Rhine channels, additional palaeosols (mostly one extra) are found within the WM. Berendsen \& Stouthamer $(2001 ;$ 2002) have hypothesized an Allerød age for the lower horizon in the western part of the Netherlands, extrapolating genetical models established for the Lower Meuse valley upstream of the study area (e.g.
Berendsen et al., 1995). They used this hypothesis to map the extension of pre-Allerød braid plains: in areas with two vegetation horizons, pre-Allerød braid plains must be present. Lithogenetical considerations (this paper) and ${ }^{14} \mathrm{C}$ and OSL dating evidence from within and below the WM invalidate this hypothesis (60, this paper; also Busschers et al., 2005). Palaeosols that occur within the WM in the western Netherlands are by majority of EH age, just as the palaeosol in its top. Rather than identifying patches of pre-Allerød braid belt surfaces, areas with double palaeosols predominantly overly channel belts of Younger Dryas and Preboreal age. In the study area four vegetation horizons are indentified, each of subregional extent and of different EH age (compare dates 98, 111 with dates 57 $60)$. This indicates the $\mathrm{EH}$ in the western Netherlands to have been more dynamic regarding natural levee and overbank deposition history than previously realised. The temporal and spatial distribution of the WM thus reflects the complex avulsion history of EH-channels.

\section{Cause for early Holocene entrenchments}

Rhine discharge in our study area was split over two parallel running channel belts until the late Boreal (Fig. 15). Channel belts of Preboreal and Boreal age show deep scour. The scour depth observed at Schiedam (Fig. 17; 19 m below river plain; $37 \mathrm{~m}$-0.D.) is enigmatically deep compared to scour features in Rhine channel belts of similar age in upstream reaches. Berendsen et al. (1995) and Cohen (2003) reported on deep residual channels in the upstream Rhine-Meuse delta, but none are deeper than $8 \mathrm{~m}$ below the coeval floodplain. Van Heteren et al. (2002) described channel fills offshore the present coastline that reach depths of $35 \mathrm{~m}-0 . \mathrm{D}$., similar to the scour at Schiedam. The top of the offshore channel fill deposits occurs between 19 and $23.5-0 . D$. Most of them are partly embedded within (and sometimes topped by) a several metres thick, finegrained unit that is comparable to the WM and mainly of (Pre)Boreal age. The similar age and scour depth of the offshore channels and the Schiedam channel suggests that they belong to the same channel belt and have incised this deep by one shared process. Van Heteren et al. (2002) interpreted the offshore fills as estuarine and suggested local scouring in tidal inlets as a possible mechanism for the deep thalweg of several channels. However, at the time of entrenchment (Preboreal-early Boreal, see description Fig. 17) relative sea level was well below $30 \mathrm{~m}-0$. ., based on eustatic levels from e.g. Fairbanks (1989) and modelled levels by Vink et al. (2007), excluding the possibility of nearby tidal inlets. Also, the entrenched channel at Schiedam and the entrenched channels 
offshore lie $\sim 40 \mathrm{~km}$ apart, excluding local tidal inlet scour. The offshore channel fills can well be of estuarine nature, but the initial entrenchment self cannot. De Groot \& De Gans (1996) after Roep et al. (1975) and Smith (1985) suggested a relation with the breach of the Dover Strait, but this occurred during pre-Weichselian glacials (Gibbard et al., 1988; Gupta et al., 2007; Busschers et al., 2008). An interesting new finding is that the deeply entrenched systems are most likely all situated outside the West-Netherlands Basin on the southern slower subsiding area underlain by the London-Brabant massif (Fig. 1). This is suggested by the presence of an active fault immediately upstream from the Schiedam entrenchment (Figs 1, 16, 17). This would have led to more scour than in the WNB, although the differential scour depth can be at maximum the difference in subsidence, in this case only a few metres. It can therefore not explain the excessive scour completely. Another possibility is the difference in channel bank erodibility downstream of Schiedam due to the earlier start of aggradation and hence thicker layers of fine grained overbank deposits than in areas upstream of Schiedam. This could have hindered lateral migration of EH channel belts, stimulating more confined and hence deeper scour than in areas upstream of Schiedam. A less likely option is the scouring effect of water trapped under a frozen river surface during a period of sudden discharge increase. This effect could have been strongest in areas of low river gradient (i.e. downstream of the delta hinge line, in the late Preboreal situated close to Schiedam), as ice cover would have been thickest there due to lower flow velocities and hence less likely to break up during an increase of discharge.

\section{Valley floor gradient}

Younger Dryas and (Pre)Boreal channel belt surfaces occur in incised position. The cross-sections allow determining their elevation relative to older and younger systems. The lowest recognized valley floors in the study area (e.g. km $30-31$, Fig. 16; km 46 - 48 Fig. 17) represent their youngest phase (see also Busschers et al., 2007). These valley floor levels lie on average $\sim 1 \mathrm{~m}$ lower than the surrounding valley floors and the width over which they are lower excludes the possibility of locally encountered variability. Upstream, the lowest valley floor was named Terrace $\mathrm{X}$ and is situated up to $2 \mathrm{~m}$ lower than the surrounding valley floor or Lower Terrace. The lower gradient of Terrace $\mathrm{X}$ results in a downstream decrease in differential elevation (Pons, 1957). By extrapolating the gradient lines to the west, Pons (1957) suggested the terraces to merge somewhere offshore the present coast line. Based on extrapolating the Lower Terrace gradient of Pons (1954) and a newly constructed gradient for Terrace X, Törnqvist (1998) proposed a convergence near Rotterdam. The new data show that the intersection point between the two terraces is not situated near Rotterdam, but more to the west. It also shows that Terrace $\mathrm{X}$ represents a YD-EH valley floor and is not only of YD age. Future research on valley floor gradients should also include existing offshore seismic data (e.g. Van Heteren et al., 2002; Rieu et al., 2005).

It is important to realize that over large parts in the western Netherlands the upper few metres of the Late Glacial-EH sandy substrate consist of aeolian deposits. This has direct consequences for constructing longitudinal profiles for the Rhine-Meuse valley. This applies especially to the top of the YD-EH river plain which is overlain by many aeolian dunes and thus at a lower position than judged from merely mapping 'the top of sand' level.

The period of incision that started in the Allerød and culminated in early Boreal times (unit B6b; Busschers et al., 2007), shows that the western Netherlands was a net export area for sand. This material was transported towards nowadays offshore areas. The study area likely was a net sink for flood basin sediments during this time, testified by the widespread occurrence of the WM, draped over considerable widths of Late Glacial and EH buried terraces and flanking (Pre)Boreal channel belts.

\section{Boreal inland aeolian dune formation in the western Netherlands}

The cross-sections traverse several inland aeolian dune fields. Large aeolian sheets ( $2 \mathrm{~m}$ thick), with an occasional higher dune, are present over considerable areas, which was not realised before. Past mapping restricted the extent of dune fields to the direct vicinity of known higher dunes and presumed Younger Dryas to earliest Holocene ages (e.g. Bosch \& Kok, 1994). This study shows that some dune fields of modest height, but considerable extent, date from the late Boreal (reproducing a local observation of Pons \& Bennema, 1958). This follows from date 72 (0xcal mean 9306; Fig. 16, km 28) below an observed dune in a construction pit and date 71 (0xCal mean 9175) from a residual channel fill of a channel that dissects the same dune. Dune formation therefore occurred between 9.3 and $9.2 \mathrm{cal} \mathrm{ka} \mathrm{BP}$ and is tentavily related to the recorded 9.3 ka BP cooling event (Von Grafenstein et al., 1999; Marshall et al., 2007; Rasmussen et al., 2007). Boreal aeolian activity can also be inferred from the admixture of in-blown sand in Boreal deposited parts of WM (Van der Woude, 1983). In the eastern part of the Netherlands several dunes were 
palynologically dated at the Younger Dryas (Pons, 1957) and we do not exclude older ages for adjacent dune fields of greater height in the Rotterdam area. Multiple OSL-dating on inland aeolian dunes is needed to constrain different periods of dune formation.

\section{Estuarine evolution: bay-head delta formation}

Between 8 and $7.3 \mathrm{ka}$, a 3 - $4 \mathrm{~km}$ wide and $\sim 4$ - 5 m thick sand body was deposited near Delft (Delft sands, km 39 - 46, Fig. 17) that can be connected to upstream fluvial channel belts, strongly suggesting a fluvial source for the sediment. This is also apparent from the predominantly fresh water depositional environment, evident from vivianite stains and diatom analysis. Based on the deltaic geometry (Fig. 15), the presence of tidal structures and brackish-water fauna, the fluvial source and the stratigraphic position between fluvial deposits below and tidal basin deposits above, we interpret the Delft sands as a bayhead delta deposit formed in the upper estuary (see also Fig. 7). Unfortunately, most cores end in the top of the sand body that is only fully penetrated by a few cores. The top of the sand body generally consists of very fine sands (110 - $150 \mu \mathrm{m})$. Too little information is available to describe the upward trend in grain size within the sand body, although core B37E570 (Fig. 8) seems to show a fining upward succession. Generally though, bay-head delta's show an overall coarsening upward succession (Boyd et al., 2006). Possibly the fining-upward unit represents a bay-head delta distributary channel. However, during rapid SLR and continuous rapid landward migration of the whole estuarine system, it can be imagined that a bay-head delta succession may show a general fining-upward trend.

The formation of the delta means that little sand reached the open sea and hence hardly any fluvial sand was available for alongshore transport and barrier formation. Seaward of the bay-head delta and seaward of Fig. 17, a central basin must have been present. Water depths in this basin would have been shallow (maximum $5 \mathrm{~m}$ ), as sea level was $\sim 10 \mathrm{~m}-0 . \mathrm{D}$. and the drowned EH surface is encountered at $15 \mathrm{~m}-0 . \mathrm{D}$. The formation of mouth bars in the bay-head delta would have led to channel bifurcations. Such process may have driven the avulsions that made the Rhine partially abandon the Delft area after $7.7 \mathrm{ka}$. It is striking that at the river mouths of the younger channel belts \#177 and \#133 no bay-head deltas have been recognized. If they existed, a lack of corings near the mouth of \#177 is the most likely explanation for not encountering it. The bay-head delta of \#133 would have been largely reworked during subsequent progradation of the channel belt and very poorly preserved and hard to recognize.

\section{Conclusions}

Our integrative approach allowed reconstructing the age, tidal and fluvial facies distribution and architecture of the deeper Holocene subsurface of the Rhine-Meuse delta. The main conclusions regard the transformation from fluvial valley to estuary:

- The Younger Dryas - (Pre)Boreal period is characterized by one major Meuse and two major Rhine channel belts that were reworking Late Glacial deposits while lowering their beds.

- Widespread inland aeolian activity along river beds occurred in the Younger Dryas and Preboreal, but also during the Boreal.

- Convergence of late Pleniglacial and Younger Dryas-early Holocene valley floors does not occur near Rotterdam, but more to the west.

- In the early Atlantic aggradation started and Rhine discharge began to concentrate in the northern part of the palaeovalley. Outside the channel-belt areas, widespread peat formation started $\sim 9 \mathrm{ka}$ and ended between 8.5 and $8 \mathrm{ka}$. By that time most parts of the study area were permanently flooded and tidally influenced. The central part of the valley remained fresh due to river discharge, while at the fringes slightly brackish environments existed.

- After $8 \mathrm{ka}$ a bay-head delta formed near Delft. This means that almost all sandy sediment was trapped in the backbarrier basin and did not reach the North Sea and could not contribute to barrier formation. Several avulsions resulted in a stepped northward shift of the constantly retreating Rhine river mouth into a tidal basin. The Meuse still debouched south of Rotterdam. In the upper estuary, silty clays with woody debris, were rapidly deposited.

- After 6.5 ka the Oude Rijn-estuary was formed and the central part of the palaeo-valley was quickly transgressed and transformed into a large tidal basin. Shortly before 6 ka retrogradation of the coastline halted and tidal inlets began to close.

This article describes the transition from a river valley to an estuary in unprecedented detail and enables more detailed palaeo-reconstructions, evaluation of relative importance of fluvial and coastal processes in rapid transgressed river mouths, and more accurate sediment-budget calculations. The described and well illustrated (changes in) facies are linked to lithogenetic units. This will aid detailed palaeogeographic interpretations from sedimentary successions, not only in the RhineMeuse delta, but also in other estuarine and deltaic areas. 


\section{Acknowledgements}

This article is part of the Ph.D.-research of Marc Hijma at the Utrecht University (UU), carried out within the Utrecht Centre of Geosciences (UCG). It could not have been written without the cooperation of many organizations who very willingly shared their subsurface data and insights. Many thanks to the municipality of Rotterdam: the help of Ton Guiran and Jurrien Moree from the Bureau Oudheidkundig Onderzoek Rotterdam (B00R) and Robert Berkelaar and F.M. Freyre Hechavarria from Ingenieursbureau Rotterdam is highly appreciated. Especially the visits to the construction pits contributed much to our way of looking at and understanding of early-middle Holocene depositional environments. Thanks to Ruben Lelivelt (formerly at B00R) for his help and saving of important cored sediments. The people of the Projectorganisatie HSL-Zuid are thanked for the permission to use detailed subsurface information obtained along the HSL-railroad, partly provided to us by Wim Nohl (Fugro Ingenieursbureau B.V.). Furthermore, Rien de Rijke of the municipality of Zoetermeer is thanked for the usage of the city's digital subsurface database. We express our gratitude to all the farmers and organizations that let us drill on their land and to all the people who volunteered for fieldwork, especially Thijs Nales, John van Tol and Ingwer Bos. Thanks to Hanneke Bos and Nelleke van Asch for selecting the macrofossils for AMS-dating. Pollen and diatom analysis have been done by Frans Bunnik and Holger Cremer respectively. Jakob Wallinga and Alice Versendaal of the Netherlands Centre for Luminescence Dating (NCL: www.lumid.nl) are thanked for preparing and dating our OSL-samples, sponsored by The Netherlands Organisation for Scientific Research (NW0: grant \#834.03.003). Jakob Wallinga is also thanked for providing the description of the followed OSL-procedure. Thanks to Sytze van Heteren for discussion. Gösta Hoffmann thanks the Deutsche Forschungsgemeinschaft for sponsoring his 2 year stay at Utrecht University (grant Ho 2550/2-1). The reviews from Bob Dalrymple and Cecile Baeteman are highly appreciated for their helpful suggestions and remarks. This paper is a contribution to IGCP Project 495 `Late Quaternary Land-0cean Interactions: Driving Mechanisms and Coastal Responses'.

This paper is dedicated to the late Henk Berendsen and Leen Pons, whose profound understanding of the evolution of the Rhine-Meuse delta is so much reflected in this paper.

\section{References}

Allen, J.R.L., 1990. The Severn Estuary in southwest Britain: its retreat under marine ingression, and fine-sediment regime. Sedimentary Geology 66: 13-28.

Ardies, G.W., Dalrymple, R.W. \& Zaitlin, B.A., 2002. Controls on the geometry of incised valleys in the basal quartz unit (Lower Cretaceous), western Canada sedimentary basin. Journal of Sedimentary Research 72 (5): 602-618.

Autin, W.J., 2008. Stratigraphic analysis and paleoenvironmental implications of the Wijchen Member in the lower Rhine-Meuse valley of the Netherlands. Netherlands Journal of Geosciences - Geologie en Mijnbouw 87 (4): 291-307.

Ballarini, M., Wallinga, J., Wintle, A.G. \& Bos, A.J.J., 2007. A modified SAR protocol for optical dating of individual grains from young quartz samples. Radiation Measurements 42 (3): 360-369.

Beets, D.J. \& Van der Spek, A.J.F., 2000. The Holocene evolution of the barrier and the back-barrier basins of the Belgium and the Netherlands as a function of late Weichselian morphology, relative sea-level rise and sediment supply. Netherlands Journal of Geosciences - Geologie en Mijnbouw 79: 3-16.

Beets, D.J., Van der Valk, L. \& Stive, M.J., 1992. Holocene evolution of the coast of Holland. Marine Geology 103: 423-444.

Berendsen, H.J.A., 2005. De Laaglandgenese Databank. Department of Physical Geography, Faculty of Geosciences, Utrecht University.

Berendsen, H.J.A., Cohen, K.M. \& Stouthamer, E., 2007. The use of GIS in reconstructing the Holocene palaeogeography of the Rhine-Meuse delta, the Netherlands. International Journal of Geographical Information Science 21 (5): 589-602.

Berendsen, H.J.A., Hoek, W.Z. \& Schorn, E.A., 1995. Late Weichselian and Holocene river channel changes of the rivers Rhine and Meuse in the central Netherlands (Land van Maas en Waal). In: Frenzel, B. (ed.): European river activity and climate change during the Lateglacial and Early Holocene. ESF Project European Paläoklimaforschung / Paleoclimate Research, Special Issue 151-171

Berendsen, H.J.A. \& Stouthamer, E., 2000. Late Weichselian and Holocene palaeogeography of the Rhine-Meuse delta, the Netherlands. Palaeogeography, Palaeoclimatology, Palaeoecology 161 (3-4): 311-335.

Berendsen, H.J.A. \& Stouthamer, E., 2001. Palaeogeographic development of the Rhine-Meuse delta, the Netherlands. Koninklijke van Gorcum (Assen): 268 pp.

Berendsen, H.J.A. \& Stouthamer, E., 2002. Paleogeographic evolution and avulsion history of the Holocene Rhine-Meuse delta, the Netherlands. Netherlands Journal of Geosciences - Geologie en Mijnbouw 81 (1): 97-112.

Berendsen, H.J.A. \& Volleberg, K.P., 2007. New prospects in geomorphological and geological mapping of the Rhine-Meuse Delta - Application of detailed digital elevation maps based on laser altimetry. Netherlands Journal of Geosciences - Geologie en Mijnbouw 86 (1): 15-22.

Bosch, J.H.A. \& Kok, H., 1994. Toelichting bij de geologische kaart van Nederland $1: 50.000$, Blad Gorinchem West (38 W), Rijks Geologische Dienst (Haarlem): $159 \mathrm{pp}$. 
Boyd, R., Dalrymple, R.W. \& Zaitlin, B.A., 2006. Estuarine and incised-valley facies models. In: Posamentier, H.W. and Walker, R.G. (eds): Facies models revisited. SEPM Special Publication, 84. SEPM (Tulsa, Oklahoma, U.S.A.): 171-235.

Bronk Ramsey, C., 1995. Radiocarbon calibration and analysis of stratigraphy: The 0xCal program. Radiocarbon 37 (2): 425-430.

Bronk Ramsey, C., 2001. Development of the radiocarbon calibration program 0xCal. Radiocarbon 43 (2A): 355-363.

Busschers, F.S., Kasse, C., Van Balen, R.T., Vandenberghe, J., Cohen, K.M., Weerts, H.J.T., Wallinga, J., Johns, C., Cleveringa, P. \& Bunnik, F.P.M., 2007. Late Pleistocene evolution of the Rhine-Meuse system in the southern North Sea basin: imprints of climate change, sea-level oscillation and glacioisostacy. Quaternary Science Reviews 26 (25-28): 3216-3248.

Busschers, F.S., Van Balen, R.T., Cohen, K.M., Kasse, C., Weerts, H.J.T., Wallinga, J. \& Bunnik, F.P.M., 2008. Response of the Rhine-Meuse fluvial system to Saalian ice-sheet dynamics. Boreas 0 (0): ???-???

Busschers, F.S., Weerts, H.J.T., Wallinga, J., Cleveringa, P., Kasse, C., De Wolf, H.

\& Cohen, K.M., 2005. Sedimentary architecture and optical dating of Middle and Late Pleistocene Rhine-Meuse deposits - fluvial response to climate change, sea-level fluctuation and glaciation. Netherlands Journal of Geosciences - Geologie en Mijnbouw 84: 25-41.

Chambers, R.M., Meyerson, L.A. \& Saltonstall, K., 1999. Expansion of Phragmites australis into tidal wetlands of North America. Aquatic Botany 64 (3-4): 261-273.

Cleveringa, J., 2000. Reconstruction and modelling of Holocene coastal evolution of the western Netherlands. Ph.D.-thesis, Utrecht University: 197 pp.

Coerts, A., 1996. Analysis of static cone penetration test data for subsurface modelling - a methodology. Ph.D.-thesis, Utrecht University (Utrecht): 263 pp.

Cohen, K.M., 2003. Differential subsidence within a coastal prism. Late-Glacial Holocene tectonics in the Rhine-Meuse delta, the Netherlands. Ph.D.-thesis, Utrecht University: $176 \mathrm{pp}$.

Cohen, K.M., 2005. 3D geostatistical interpolation and geological interpolation of palaeo-groundwaterrise within the coastal prism in the Netherlands. In: Giosan, L. and Bhattacharaya, J.P. (eds): River Deltas: Concepts, models, and examples SEPM (Society for Sedimentary Geology) (Tulsa, 0klahoma): 341-364.

Cohen, K.M. \& Hijma, M.P., 2008. Het Rijnmond gebied in het vroeg-Holoceen: inzichten uit een diepe put bij Blijdorp (Rotterdam). Grondboor en Hamer 3/4: 64-71 (in Dutch).

Cremer, H., Wagner, B., Melles, M. \& Hubberten, H.-W., 2001. The postglacial environmental development of Raffles $\varnothing \emptyset$, East Greenland: inferences from a 10,000 year diatom record. Journal of Paleolimnology 26: 67-87.

Dalrymple, R.W., Boyd, R. \& Zaitlin, B.A. (eds), 1994. Incised-valley systems: origin and sedimentary sequences. Spec. Publ. Soc. Sedim. Geol. 51, Tulsa: 391.

Dalrymple, R.W. \& Choi, K., 2007. Morphologic and facies trends through the fluvial-marine transition in tide-dominated depositional systems: A schematic framework for environmental and sequence-stratigraphic interpretation. Earth-Science Reviews 81 (3-4): 135-174.
Dalrymple, R.W., Zaitlin, B.A. \& Boyd, R., 1992. Estuarine facies models: conceptual basis and stratigraphic implications. Journal of Sedimentary Research 62: 1130-1146.

De Groot, T.A.M. \& De Gans, W., 1996. Facies variations and sea-level response in the lower Rhine-Meuse area during the last 15000 years (the Netherlands). In: Beets, D.J., Fischer, M.M. and De Gans, W. (eds): Coastal studies on the Holocene of the Netherlands. Mededelingen Rijks Geologische Dienst. Rijks Geologische Dienst (Haarlem): 229-250.

De Wolf, H., 2002. Personal communication, Geological Survey of the Netherlands, Utrecht.

Den Held, A., Schmitz, M. \& Van Wirdum, G., 1992. Types of terrestrializing fen vegetation in the Netherlands. In: Verhoeven, J.T.A. (ed.): Fens and bogs in the Netherlands: vegetation, history, nutrient dynamics and conservation. Geobotany. Kluwer Academics Publishers (Dordrecht): 237-321.

Faegri, K. \& Iversen, J., 1975. Textbook of Pollen Analysis. 3rd edition, Munksgaard (Copenhagen): $295 \mathrm{pp}$.

Fagel, N., Alleman, L.Y., Granina, L., Hatert, F., Thamo-Bozso, E., Cloots, R. \& Andre, L., 2005. Vivianite formation and distribution in Lake Baikal sediments. Global and Planetary Change 46 (1-4): 315-336.

Fairbanks, R.G., 1989. A 17,000-year glacio-eustatic sea level record: influence of glacial melting rates on the Younger Dryas event and deep-ocean circulation. Nature 342: 637-642.

Frouin, M., Sebag, D., Durand, A., Laignel, B., Saliege, J.-F., Mahler, B.J. \& Fauchard, C., 2007. Influence of paleotopography, base level and sedimentation rate on estuarine system response to the Holocene sea-level rise: the example of the Marais Vernier, Seine estuary, France. Sedimentary Geology 200 (1-2): $15-29$.

Galbraith, R.F. \& Green, P.F., 1990. Estimating the component ages in a finite mixture. Nuclear Tracks and Radiation Measurements 17: 197-206.

Gibbard, P.L., Rose, J. \& Bridgland, D.R., 1988. The History of the Great Northwest European Rivers During the Past Three Million Years (and Discussion]. Philosophical Transactions of the Royal Society of London. Series B, Biological Sciences 318 (1191): 559-602.

Gouw, M.J.P., 2002. Toelichting op het Geologisch Profiel Zwijndrechtse Waard en Hoekse Waard, Projectgroep Archeologie HSL-Zuid/A16, RWS/RACM (Amersfoort): 29 (in Dutch) pp.

Gouw, M.J.P., 2007. Alluvial architecture of fluvio-deltaic successions: a review with special reference to Holocene settings. Netherlands Journal of Geosciences - Geologie en Mijnbouw 86 (3): 211-228.

Gouw, M.J.P. \& Erkens, G., 2007. Architecture of the Holocene Rhine-Meuse delta (the Netherlands) - A result of changing external controls. Netherlands Journal of Geosciences - Geologie en Mijnbouw 86 (1): 23-54.

Gupta, S., Collier, J.S., Palmer-Felgate, A. \& Potter, G., 2007. Catastrophic flooding origin of shelf valley systems in the English Channel. Nature 448 (7151): 342-345.

Hijma, M.P. \& Cohen, K.M., in prep. Timing and magnitude of the sea-level jump preluding the $8,200 \mathrm{yr}$ event. 
Hoek, W.Z., 2001. Vegetation response to the $\sim 14.7$ and $\sim 11.5$ ka cal. BP climate transitions: is vegetation lagging climate? Global and Planetary Change 30 (1-2): 103-115.

Hoek, W.Z., 2008. The Last Glacial-Interglacial Transition. Episodes 31 (2): 226-229. Jelgersma, S., 1961. Holocene sea-level changes in the Netherlands. Mededelingen Geologische Stichting 7: 1-101.

Kiden, P., Denys, L. \& Johnston, P., 2002. Late Quaternary sea-level change and isostatic and tectonic land movement along the Belgian-Dutch North Sea coast: geological data and model results. Journal of Quaternary Science 17: 535-546.

Kooi, H., Johnston, P., Lambeck, K., Smither, C. \& Ronald, M., 1998. Geological causes of recent ( 100 yr) vertical land movement in the Netherlands. Tectonophysics 299 (4): 297-316.

Lambeck, K., Smither, S. \& Johnston, P., 1998. Sea-level change, glacial rebound and mantle viscosity for Northern Europe. Geophys. J. Int. 134: 102-144.

Makaske, B., 2001. Anastomosing rivers: a review of their classification, origin and sedimentary products. Earth-Science Reviews 53 (3-4): 149-196.

Marshall, J.D., Lang, B., Crowley, S.F., Weedon, G.P., Van Calsteren, P., Fisher, E.H., Holme, R., Holmes, J.A., Jones, R.T., Bedford, A., Brooks, S.J., Bloemendal, J., Kiriakoulakis, K. \& Ball, J.D., 2007. Terrestrial impact of abrupt changes in the North Atlantic thermohaline circulation: Early Holocene, UK\&\#8224. Geology 35 (7): 639-642.

Murray, A.S. \& Wintle, A.G., 2003. The single aliquot regenerative dose protocol: potential for improvements in reliability. Radiation Measurements 37 (4-5): 377-381.

Oele, E., Apon, W., Fischer, M.M., Hoogendoorn, R., Mesdag, C.S., De Mulder, E.F.J., Overzee, B., Sesören, A. \& Westerhoff, W.E., 1983. Surveying the Netherlands, Sampling Techniques, Maps and their application. Geologie en Mijnbouw 62: 355-372.

Peltier, W.R., 2002. On eustatic sea level history: Last Glacial Maximum to Holocene. Quaternary Science Reviews 21 (1-3): 377-396.

Peltier, W.R., 2004. Global glacial isostasy and the surface of the ice-age earth: the ICE-5G (VM2) model and grace. Annual Review of Earth and Planetary Science 32: 111-149.

Pons, L.J., 1954. Het fluviatiele laagterras van Rijn en Maas. Boor en spade 7: 97110 (in Dutch).

Pons, L.J., 1957. De geologie, bodemvorming en de waterstaatkundige ontwikkeling van het Land van Maas en Waal en een gedeelte van het Rijk van Nijmegen. Ph.D.-thesis, Wageningen University (Wageningen): 156 pp. (In Dutch, with English summary).

Pons, L.J. \& Bennema, J., 1958. De morfologie van het Pleistocene oppervlak in westelijk Midden-Nederland, voor zover gelegen beneden gemiddeld zeeniveau (N.A.P.). Tijdschrift van het Koninklijk Nederlandsch Aardrijkskundig Genootschap 75 (2): 121-138 (in Dutch).

Pons, L.J., Jelgersma, S., Wiggers, A.J. \& De Jong, J.D., 1963. Evolution of the Netherlands coastal area during the Holocene. In: De Jong, J.D. (ed.): Verhandelingen van het KNGMG: Transactions of the jubilee convention part two. N.V. Boek- Kunstdrukkerij v/h Mouton \&Co. ('s Gravenhage): 197-207.
Rasmussen, S.O., Andersen, K.K., Svensson, A.M., Steffensen, J.P., Vinther, B.M., Clausen, H.B., Siggaard-Andersen, M.-L., Johnsen, S.J., Larsen, L.B., Dahl-Jensen, D., Bigler, M., Röthlisberger, R., Fischer, H., Goto-Azuma, K., Hansson, M.E. \& Ruth, U., 2006. A new Greenland ice core chronology for the last glacial termination. Journal of Geophysical Research 111: D06102.

Rasmussen, S.O., Vinther, B.M., Clausen, H.B. \& Andersen, K.K., 2007. Early Holocene climate oscillations recorded in three Greenland ice cores. Quaternary Science Reviews 26 (15-16): 1907-1914.

Raven, J.G.M. \& Kuijper, W.J., 1981. Calais Deposits (Holocene) near Benthuizen (Province of Zuid-Holland, the Netherlands), with a palaeoecological reconstruction. Meded. Werkgr. Tert. en Kwart. Geol. 18: 11-28.

Reimer, P.J., Baillie, M.G.L., Bard, E., Bayliss, A., Beck, J.W., Bertrand, C.J.H., Blackwell, P.G., Buck, C.E., Burr, G.S., Cutler, K.B., Damon, P.E., Edwards, R.L., Fairbanks, R.G., Friedrich, M., Guilderson, T.P., Hogg, A.G., Hughen, K.A., Kromer, B., McCormac, G., Manning, S., Bronk Ramsey, C., Reimer, R.W., Remmele, S., Southon, J.R., Stuiver, M., Talamo, S., Taylor, F.W., Van der Plicht, J. \& Weyhenmeyer, C.E., 2004. INTCAL04 Terrestrial radiocarbon age calibration, 0 - 26 cal kyr BP. Radiocarbon 46 (3): 1029-1058.

Reinson, G.E. (ed.), 1992. Transgressive barrier island and estuarine systems. Facies Models - Response to Sea Level Change, Reprint Series 4: 179-194.

Reynaud, J.-Y., Tessier, B., Proust, J.-N., Dalrymple, R.W., Bourillet, J.-F., De Batist, M., Lericolais, G., Berné, S. \& Marsset, T., 1999. Architecture and sequence stratigraphy of a Late Neogene incised valley at the shelf margin, southern Celtic Sea. Journal of Sedimentary Research 69 (2): 351-364.

Rieu, R., Van Heteren, S., Van der Spek, A.J.F. \& De Boer, P.L., 2005. Development and Preservation of a Mid-Holocene Tidal-Channel Network Offshore the Western Netherlands. Journal of Sedimentary Research 75 (3): 409-419.

Rijkswaterstaat-AGI, 2005. Actueel Hoogtebestand Nederland (AHN). Revised version. Rijkswaterstaat, Adviesdienst Geo-informatie en ICT, Delft.

Rodnight, H., Duller, G.A.T., Wintle, A.G. \& Tooth, S., 2006. Assessing the reproducibility and accuracy of optical dating of fluvial deposits. Quaternary Geochronology 1 (2): 109-120.

Roep, T.B., Holst, H., Vissers, R.L.M., Pagnier, H. \& Postma, D., 1975. Deposits of southward-flowing, pleistocene rivers in the channel region, near Wissant, NW France. Palaeogeography, Palaeoclimatology, Palaeoecology 17 (4): 289-308.

Schirmer, W., 1995. Valley bottoms in the Late Quaternary - der Talgrund in im jüngeren Quartär. Zeitschrift für Geomorphologie N.F. Supplement 100: 27-51.

Silberhorn, G.M., 1999. Common plants of the Mid-Atlantic coast: a field guide. Revised edition. The John Hopkins University Press (Baltimore): 294 pp.

Smith, A.J., 1985. A catastrophic origin for the palaeovalley system of the eastern English Channel. Marine Geology 64 (1-2): 65-75.

Stanley, D.J. \& Warne, A.G., 1994. Worldwide initiation of Holocene marine deltas by deceleration of sea-level rise. Science 265: 228-231.

Steffen, H., 2006. Determination of a consistent viscosity distribution in the earth's mantle beneath Northern and Central Europe. Ph.D.-thesis, Institut für Geologische Wissenschaften der Freie Universität Berlin (Berlin, Germany). 
Stortelder, A.H.F., Hommel, P.W.F.M., De Waal, R.W., Van Dort, K.W., Vrielink,

J.G. \& Wolf, R.J.A.M., 1998. Broekbossen. Natuurhistorische bibliotheek 66. Stichting Uitgeverij van Koninklijke Nederlandse Natuurhistorische Vereniging (Utrecht). (In Dutch).

Stuiver, M., Pearson, G.W. \& Braziunas, T.F., 1986. Radiocarbon Age Calibration of Marine Samples Back to 9000 cal yr BP. Radiocarbon 28 (2B): 980-1021.

Terwindt, J.H.J., De Jong, J.D. \& Van der Wilk, E., 1963. Sediment movement and sediment properties in the tidal area of the Lower Rhine (Rotterdam Waterway). Verhandelingen KNGMG 21 (2): 243-258.

TNO, 2009. DINOloket (Internet Portal for Geo-Information), www.dinoloket.nl.

Törnqvist, T.E., 1993. Fluvial sedimentary geology and chronology of the Holocene Rhine-Meuse delta, the Netherlands. Ph.D.-thesis, Utrecht University: 169 pp.

Törnqvist, T.E., 1998. Longitudinal profile evolution of the Rhine-Meuse system during the last deglaciation: interplay of climate change and glacio-eustasy? Terra Nova 10 (1): 11-15.

Törnqvist, T.E., De Jong, A.F.M., Oosterbaan, W.A. \& Van der Borg, K., 1992. Accurate dating of organic deposits by AMS $14 \mathrm{C}$ measurement of macrofossils. Radiocarbon 34 (3): 566-577.

Törnqvist, T.E., Weerts, H.J.T. \& Berendsen, H.J.A., 1994. Definition of two new members in the upper Kreftenheye and Twente Formations (Quaternary, the Netherlands): a final solution to persistent confusion? Geologie en Mijnbouw 72: $251-264$

Van Balen, R.T., Van Bergen, F., De Leeuw, C., Pagnier, H., Simmelink, H., Van Wees, J.D. \& Verweij, J.M., 2000. Modelling the hydrocarbon generation and migration in the West Netherlands Basin, the Netherlands. Netherlands Journal of Geosciences - Geologie en Mijnbouw 79 (1): 29-44.

Van de Plassche, 0., 1982. Sea-level change and water-level movements in the Netherlands during the Holocene. Ph.D.-thesis, Vrije Universiteit (Amsterdam): 93 pp.

Van den Berg, J.H., Boersma, J.R. \& Van Gelder, A., 2007. Diagnostic sedimentary structures of the fluvial-tidal transition zone - Evidence from deposits of the Rhine and Meuse. Netherlands Journal of Geosciences - Geologie en Mijnbouw 86 (3): 287-306.

Van der Molen, J. \& De Swart, H.E., 2001a. Holocene tidal conditions and tideinduced sand transport in the southern North Sea. Journal of Geophysical Research C 106: C5, 9339-9362.

Van der Molen, J. \& De Swart, H.E., 2001b. Holocene wave conditions and waveinduced sand transport in the southern North Sea. Continental Shelf Research 21 (16-17): 1723-1749.

Van der Molen, J. \& Van Dijck, B., 2000. The evolution of the Dutch and Belgian coasts and the role of sand supply from the North Sea. Global and Planetary Change 27 (1-4): 223-244.

Van der Spek, A.J.F. \& Beets, D.J., 1992. Mid-Holocene evolution of a tidal basin in the western Netherlands: a model for future changes in the northern Netherlands under conditions of accelerated sea-level rise? Sedimentary Geology 80 (3-4): 185-197.
Van der Spek, A.J.F., Cleveringa, J. \& Van Heteren, S., 2007. From transgression to regression: coastal evolution near The Hague, the Netherlands, around 5000 BP. In: Kraus, N.C. and Dean Rosati, J. (eds): Coastal sediments '07, Proceedings of the 6th International Symposium on Coastal Engineering and Science of Coastal Sediments Processes (New Orleans, Louisiana): 1129-1141.

Van der Valk, L., 1996. Geology and sedimentology of Late-Atlantic sandy, wavedominated deposits near The Hague (South-Holland, the Netherlands): a reconstruction of an early prograding coastal sequence. In: Beets, D.J., Fischer, M.M. and De Gans, W. (eds): Coastal studies on the Holocene of the Netherlands. Mededelingen Rijks Geologische Dienst. Rijks Geologische Dienst (Haarlem): 201-228.

Van der Woude, J.D., 1983. Holocene paleoenvironmental evolution of a perimarine fluviatile area - Geology and paleobotany of the area surrounding the archeological excavation at the Hazendonk river dune (western Netherlands). Analecta Praehistorica Leidensia XVI: 1-124. Earlier appeared as Ph.D.-thesis (1981), Vrije Universiteit, Amsterdam.

Van Geel, B., Bohncke, S.J.P. \& Dee, H., 1980/1981. A palaeoecological study of an upper late glacial and holocene sequence from 'de borchert', the Netherlands. Review of Palaeobotany and Palynology 31: 367-392.

Van Heteren, S., Van der Spek, A.J.F. \& De Groot, T.A.M., 2002. Architecture of a preserved Holocene tidal complex offshore the Rhine-Meuse mouth, the Netherlands. NITG 01-27-A, Netherlands Institute of Applied Geoscience TNO - National Geological Survey: $40 \mathrm{pp}$.

Van Huissteden, J. \& Kasse, C., 2001. Detection of rapid climate change in Last Glacial fluvial successions in the Netherlands. Global and Planetary Change 28 (1-4): 319-339.

Van Veen, J., 1936. Transport des sables par des courants dans les cours inférieurs des rivières, dans les estuaires néerlandais et dans la Mer du Nord. VI Assemblé générale de l'Ass. Int. d'hydrologie Scientifique (Edinburgh).

Vandenberghe, J., 1985. Paleoenvironment and stratigraphy during the last glacial in the Belgian-Dutch border region. Quaternary Research 24 (1): 23-38.

Verbraeck, A., 1984. Toelichting bij de geologische kaart van Nederland $1: 50.000$, Blad Tiel West (39 W) en Blad Tiel Oost (39 0), Rijks Geologische Dienst (Haarlem): 335 pp. (In Dutch).

Verbraeck, A. \& Bisschops, J.H., 1971. Toelichting bij de geologische kaart van Nederland $1: 50.000$, Blad Willemstad 0ost (43 0), Rijks Geologische Dienst (Haarlem): 112 pp. (In Dutch).

Vink, A., Steffen, H., Reinhardt, L. \& Kaufmann, G., 2007. Holocene relative sealevel change, isostatic subsidence and the radial viscosity structure of the mantle of northwest Europe (Belgium, the Netherlands, Germany, southern North Sea). Quaternary Science Reviews 26 (25-28): 3249-3275.

Von Grafenstein, U., Erlenkeuser, H., Brauer, A., Jouzel, J. \& Johnsen, S.J., 1999. A Mid-European Decadal Isotope-Climate Record from 15,500\&nbsp;to 5000\&nbsp;Years B.P. Science 284 (5420): 1654-1657.

Vos, P.C. \& Van Heeringen, R.M., 1997. Holocene geology and occupation history of the Province of Zeeland. In: Fischer, M.M. (ed.): Holocene evolution of Zeeland (SW Netherlands). Mededelingen Rijks Geologische Dienst. Rijks Geologische Dienst (Haarlem): 5-110. 
Wallinga, J., 2002. Optically stimulated luminescence dating of fluvial deposits: a review. Boreas $31(4): 303-322$.

Westerhoff, W.E., Wong, T.E. \& De Mulder, E.F.J., 2003. Opbouw van de ondergrond - Opbouw van het Neogeen en Kwartair. In: De Mulder, E.F.J., Geluk, M.C., Ritsema, I.L., Westerhoff, W.E. and Wong, T.E. (eds): De ondergrond van Nederland. Wolters Noordhoff (Groningen/Houten): 295-352. (In Dutch).

Zagwijn, W.H., 1974. The palaeogeographic evolution of the Netherlands during the Quaternary. Geologie en Mijnbouw 53 (6): 369-385.

Ziegler, P.A., 1994. Cenozoic rift system of western and central Europe: an overview. Geologie en Mijnbouw 73: 99-127. 